RESTORED DRILL CUTTINGS FOR WETLAND CREATION: RESULTS OF A MESOCOSM APPROACH TO EMULATE FIELD CONDITIONS UNDER VARYING SALINITY AND HYDROLOGIC CONDITIONS

Final Report

January 27, 1997-January 26, 2000

By

Mark W. Hester

Gary P. Shaffer

Jonathan M. Willis

Dennis J. DesRoches

Date Published: June 2002

Work Performed Under Contract No. DE-FG22-97BC14849

Pioneer Natural Resources

Irving, Texas

National Energy Technology Laboratory National Petroleum Technology Office U.S. DEPARTMENT OF ENERGY Tulsa, Oklahoma 


\section{DISCLAIMER}

This report was prepared as an account of work sponsored by an agency of the United States Government. Neither the United States Government nor any agency thereof, nor any of their employees, makes any warranty, expressed or implied, or assumes any legal liability or responsibility for the accuracy, completeness, or usefulness of any information, apparatus, product, or process disclosed, or represents that its use would not infringe privately owned rights. Reference herein to any specific commercial product, process, or service by trade name, trademark, manufacturer, or otherwise does not necessarily constitute or imply its endorsement, recommendation, or favoring by the United States Government or any agency thereof. The views and opinions of authors expressed herein do not necessarily state or reflect those of the United States Government.

This report has been reproduced directly from the best available copy. 
Restored Drill Cuttings for Wetland Creation:

Results of a Mesocosm Approach to Emulate Field Conditions Under Varying Salinity and Hydrologic Conditions

\author{
By \\ Mark W. Hester \\ Gary P. Shaffer \\ Jonathan M. Willis \\ Dennis J. DesRoches
}

June 2002

Work Performed Under DE-FG22-97BC14849

\author{
Prepared for \\ U.S. Department of Energy \\ Assistant Secretary for Fossil Energy \\ John K. Ford, Project Manager \\ National Petroleum Technology Office \\ P.O. Box 3628 \\ Tulsa, OK 74101
}

\author{
Prepared by \\ Pioneer Natural Resources \\ 5205 N. O'Connor Blvd. \\ Suite 1400 \\ Irving, TX 75038
}


TABLE OF CONTENTS

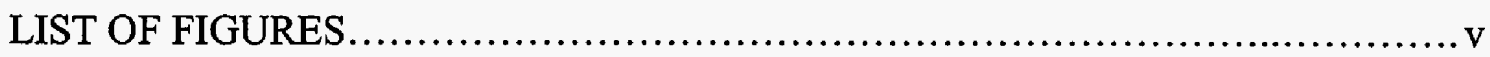

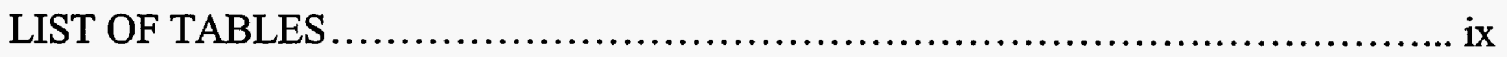

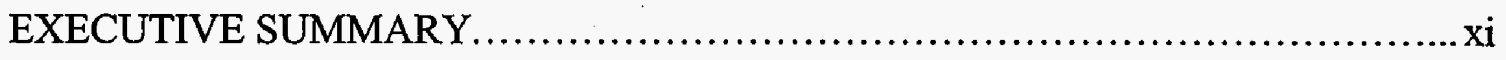

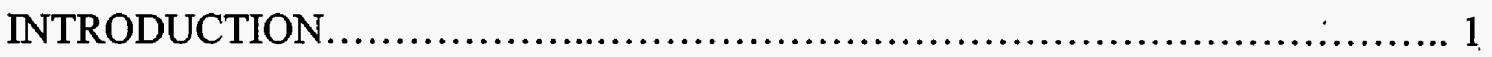

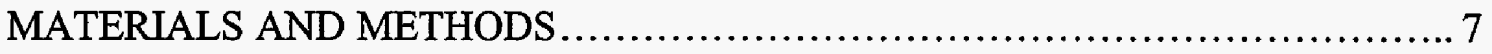

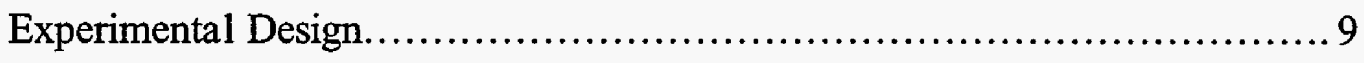

Overview............................................................. 9

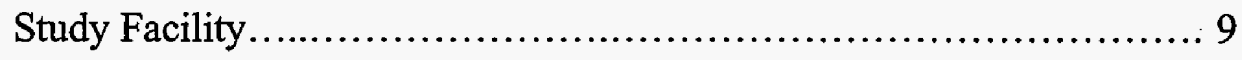

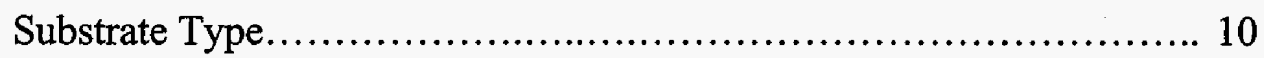

Hydrology Design.................................................. 10

Plant Treatments.................................................. 11

Salinity Levels...................................................... 12

Data Collection and Analysis............................................ 13

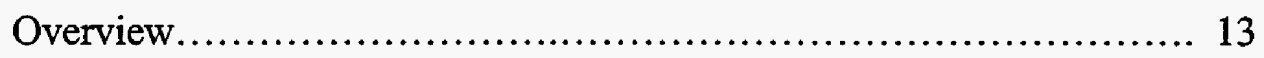

Plant Photosynthetic Response.................................... 13

Soil Reduction Potential............................................. 13

Interstitial Water Analysis........................................ 14

Biomass Measurements.............................................. 15

Stem Heights and Diameters........................................ 16

Genotype Analysis............................................. 16

Plant Tissue Analysis......................................... 16

Sediment Analysis ................................................. 17 
Statistical Analysis.............................................. 17

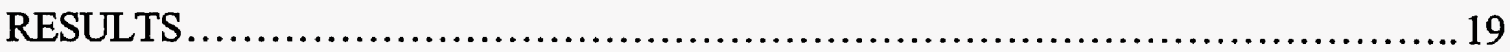

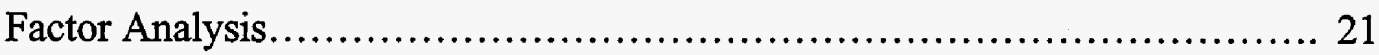

Elemental Analysis (Substrate) ......................................... 21

Elemental Analysis (Interstitial) ....................................... 21

Elemental Analysis (Vegetation) ........................................ 32

Soil Redox Potential....................................................... 40

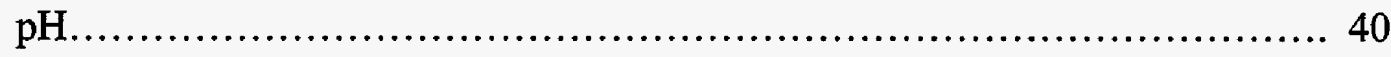

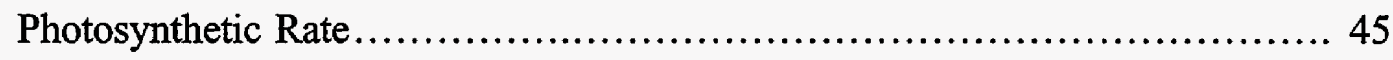

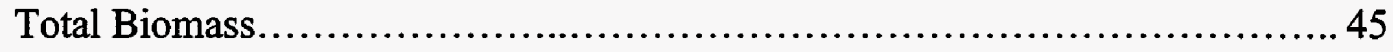

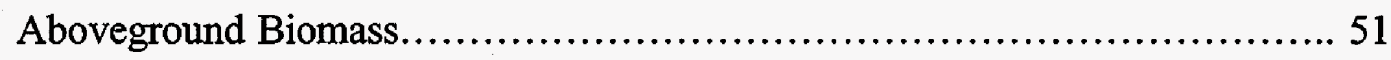

Belowground Biomass.................................................... 51

Stem Heights and Diameters............................................. 51

Genotypic Response............................................... 58

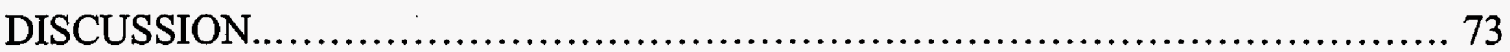

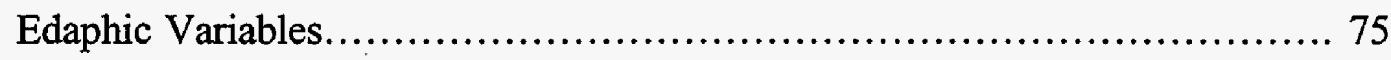

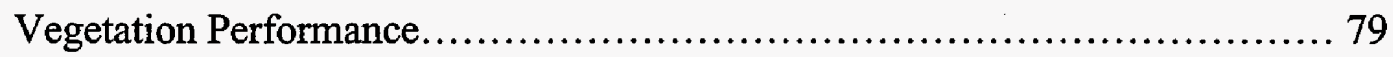

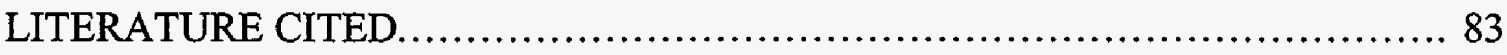

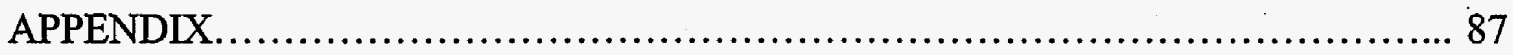




\section{List of Figures}

Figure

1. The effect of salinity level and substrate type on interstitial $\mathrm{Ca}$ concentration (mean $+/$ - standard error) averaged across hydrologic regime and plant species.

2. The effect of salinity level and hydrologic regime on substrate interstitial water $\mathrm{Ca}$ concentration (mean $+/$ - standard error) averaged across substrate type and plant species.

3. The effect of salinity level and plant species on interstitial $\mathrm{Ca}$ concentration (mean $+/$ - standard error) averaged across substrate type and hydrologic regime. Species abbreviations are as follows: $\mathrm{Sa}=S$. alterniflora, $\mathrm{Ag}=$ A. germinans, $\mathrm{Sp}=S$. patens, $\mathrm{Sc}=S$. cynosuroides.

4. The effect of salinity level, substrate type, and hydrologic regime on interstitial Fe concentration (mean $+/$ - standard error) averaged across plant species.

5. The effect of salinity level, substrate type, and hydrologic regime on interstitial $\mathrm{Mg}$ concentration (mean $+/$ - standard error) averaged across plant species

6. The effect of salinity level and substrate type on interstitial $\mathrm{Mg}$ concentration (mean $+/$ - standard error) averaged across hydrologic regime and plant species.

7. The effect of substrate type on Ba concentration (mean $+/$ - standard error) in plant tissue averaged across hydrologic regime and plant species

8. The effect of substrate type on Mn concentration (mean $+/-$ standard error) in plant tissue averaged across hydrologic regime and plant species.

9. The effect of plant species on $\mathrm{Mg}$ concentration (mean $+/$ - standard error) in plant tissue averaged across substrate type and hydrologic regime. Species abbreviations are as follows: $\mathrm{Sa}=S$. alterniflora, $\mathrm{Ag}=A$. germinans, $\mathrm{Sp}=S$. patens, $\mathrm{Sc}=S$. cynosuroides.

10. The effect of substrate type on $P$ concentration (mean $+/$ - standard error) in plant tissue averaged across hydrologic regime and plant species.

11. The effect of salinity level on soil redox (mean $+/$ - standard error) at two soil depths (1-cm and 15-cm) averaged across substrate type, hydrologic regime, and plant species.

12. The effect of hydrologic regime and salinity level on soil redox (mean $+/-$ standard error) averaged across substrate type and plant species. 
13. The effect of salinity level and substrate type on interstitial $\mathrm{pH}$ (mean +/standard error) averaged across hydrologic regime and plant species.

14. The effect of salinity level and hydrologic regime on interstitial $\mathrm{pH}$ (mean $+/$ standard error) averaged across hydrologic regime and plant species.

15. The effect of salinity level on net $\mathrm{CO}_{2}$ assimilation rate (mean $+/$ - standard error) averaged across substrate type, hydrologic regime, and plant species.

16. The effect of salinity level and substrate type on net $\mathrm{CO}_{2}$ assimilation rate (mean $+/$ - standard error) averaged across hydrologic regime and plant species.

17. The effect of substrate type, hydrologic regime, and plant species on total biomass (mean $+/$ - standard error)

18. The effect of substrate type on total biomass (mean $+/$ - standard error) averaged across hydrologic regime and plant species.

19. The effect of plant species on total biomass (mean $+/$ - standard error) averaged across substrate type and hydrologic regime. Species abbreviations are as follows: $\mathrm{Sa}=S$. alterniflora, $\mathrm{Ag}=A$. germinans, $\mathrm{Sp}=S$. patens, $\mathrm{Sc}=S$. cynosuroides.

20. Effect of substrate type, hydrologic regime, and plant species on aboveground biomass (mean $+/$ - standard error)

21. The effect of substrate type on aboveground biomass (mean $+/$ - standard error) averaged across hydrologic regime and plant species

22. The effect of plant species on aboveground biomass (mean $+/$ - standard error) averaged across substrate type and hydrologic regime. Species abbreviations are as follows: $\mathrm{Sa}=S$. alterniflora, $\mathrm{Ag}=A$. germinans, $\mathrm{Sp}=$ S.patens, $\mathrm{Sc}=S$. cynosuroides.

23. The effect of plant species on belowground biomass (mean $+/$ - standard error) averaged across substrate type and hydrologic regime. Species abbreviations are as follows: $\mathrm{Sa}=S$. alterniflora, $\mathrm{Ag}=A$. germinans, $\mathrm{Sp}=S$. patens, $\mathrm{Sc}=S$. cynosuroides.

24. The effect of substrate type on Avicennia germinans final diameter (mean $+/$ standard error) averaged across hydrologic regime.

25. The effect of substrate on Avicennia germinans final height (mean $+/$ - standard error) averaged across hydrologic regime. 
26. The effect of salinity on Spartina patens net $\mathrm{CO}_{2}$ assimilation rates, averaged across substrate type, hydrologic regime, and Spartina patens genotype

27. The effect of salinity level and substrate type on Spartina patens net $\mathrm{CO}_{2}$ assimilation (mean $+/$ - standard error) averaged across hydrologic regime and $S$. patens genotype.

28. The effect of substrate type, hydrologic regime, and Spartina patens genotype on Spartina patens aboveground biomass (mean $+/$ - standard error).

29. The effect of genotype on Spartina patens aboveground biomass (mean $+/-$ standard error) averaged across substrate type and hydrologic regime

30. The effect of genotype on Spartina patens belowground biomass (mean +/standard error) averaged across substrate type and hydrologic regime.

31. The effect of hydrologic regime on Spartina patens belowground biomass (mean $+/$ - standard error) averaged across substrate type and plant species

32. The effect of substrate type on Spartina patens belowground biomass (mean $+/$ standard error) averaged across hydrologic regime and genotype 65

33. The effect of genotype on total Spartina patens biomass (mean $+/$ - standard error) averaged across substrate type and hydrologic regime. 66

34. The effect of hydrologic regime on Spartina patens total biomass (mean +/standard error) averaged across substrate type and genotype.

35. The effect of substrate type on total Spartina patens total biomass (mean $+/-$ standard error) averaged across hydrologic regime and genotype

36. The effect of salinity level and substrate type on Spartina alterniflora net $\mathrm{CO}_{2}$ assimilation rates (mean $+/$ - standard error) averaged across hydrologic regime and genotype....

37. The effect of salinity type and genotype on Spartina alterniflora net $\mathrm{CO}_{2}$ assimilation rates (mean $+/$-standard error) averaged across substrate type and hydrologic regime 

Table

\section{List of Tables}

1. Total potentially extractable elemental concentrations in the DC-B substrate (resulting from acid digestion) prior to being subjected to any treatments in 1996 (initial) and at the end of the current study (final). Values are means $(\mu \mathrm{g} / \mathrm{g}$ soil) plus or minus standard errors in parentheses for final concentration values $(\mathrm{n}=10)$.

2. Mercury concentration in interstitial water $(\mu \mathrm{g} / \mathrm{g}$ ), pooled by substrate (across hydrology and species; $\mathrm{n}=12$ ) at the $0 \mathrm{ppt}, 9 \mathrm{ppt}$, and $36 \mathrm{ppt}$ salinity

levels.

3. Results of elemental analysis of substrate interstitial water at the end of the 0ppt salinity level. Values are mean and maximum concentrations $(\mu \mathrm{g} / \mathrm{g})$ plus or minus standard error in parentheses $(n=36)$

4. Results of elemental analysis of substrate interstitial water at the end of the 9ppt salinity level. Values are mean and maximum concentrations $(\mu \mathrm{g} / \mathrm{g})$ plus or minus standard error in parenthesis $(n=36)$.

5. Results of elemental analysis of substrate interstitial water at the end of the 36ppt salinity level. Values are mean and maximum concentrations $(\mu \mathrm{g} / \mathrm{g})$ plus or minus standard error in parenthesis $(n=36)$.

6. Results of elemental analysis of aboveground plant tissue at the end of the 0 ppt salinity level. Values are mean and maximum concentrations $(\mu \mathrm{g} / \mathrm{g}$ tissue) plus or minus standard error in parenthesis $(n=36)$

A-1. Factor Analysis of the 0-ppt salinity level substrate interstitial water elemental concentrations.

A-2. Factor Analysis of the 36-ppt salinity level substrate interstitial water elemental concentrations

A-3. Factor Analysis of totally potentially extractable DC-B sediment elemental concentrations (resulting from acid digestion)

A-4. Factor Analysis of acid digested plant elemental concentrations 



\section{Executive Summary}

Wetland loss, conservation, and restoration have become important environmental issues as the benefits of wetlands and their alarming rate of loss have become known. Louisiana, which contains $40 \%$ of the coastal wetlands in the United States, accounts for $80 \%$ of the nation's wetland loss. The need to protect and restore Louisiana's wetlands, which are an integral part of the state's and nation's productivity, is paramount.

The high rate of wetland loss in Louisiana has been largely attributed to substrate deprivation from alteration of the hydrology of the Mississippi River, canal dredging, and saltwater intrusion. Diversions of freshwater and sediment from riverine sources, and utilization of dredge material to create wetlands, have proven to be some of the most successful methods of offsetting wetland loss caused by sediment deprivation. However, some deteriorating wetlands are isolated from potential substrate sources. Therefore, a need exists to find alternative substrates and methods for wetland restoration and creation.

This study builds upon earlier research conducted by Southeastern Louisiana University concerning the efficacy of utilizing processed drill cuttings as an alternative substrate source for wetland rehabilitation (wetland creation and restoration). Previous research has indicated that processed drill cuttings exhibit a low degree of contaminant migration from the processed drill cuttings to interstitial water and a low toxicity, as tested by seven-day mysid shrimp chronic toxicity trials. Two different types of processed drill cuttings were utilized in these experiments. The first type of processed drill cuttings (hereafter referred to as DC-A) results from physical separation of the drilling fluids from the cuttings. The second type of processed drill cuttings examined (hereafter referred to as DC-B) results from further processing of DC-A by isolation and encapsulation of the cuttings in a silica matrix. Performance of plants grown on the DC-A 
substrate was comparable to both dredge spoil, a common wetland restoration substrate, and topsoil. Performance of plants grown on the DC-B substrate was greatly reduced compared to all other substrate types. This lack of plant productivity in DC-B was likely due to the high $\mathrm{pH}$ $(>10.0)$ of these drill cuttings under freshwater conditions. Although results of these initial studies were promising, concern was raised over the behavior of the processed drill cuttings under saline conditions, which was not investigated in the these earlier studies. Specifically, under saline conditions it was suggested that metals might be leached from the cuttings through cation exchange. Therefore, this mesocosm study was designed to examine the behavior of the processed drill cuttings and the productivity of common Louisiana brackish and salt marsh plants grown on them as salinities were increased from fresh water to open-ocean salinity conditions.

In this study, as was observed in the previous study, both interstitial water and plant tissue associated with the DC-A substrate exhibited low metal concentrations. Also in agreement with the previous study, plant performance in the DC-A substrate was found to be comparable to plant performance in the dredge spoil and topsoil substrates. This is extremely important because it indicates that the drill cuttings themselves may serve as an excellent substrate for wetland plant growth, but that the processing and stabilization techniques and drilling fluid formulations may require further refinement.

This study has also revealed unexpected results concerning the performance of the DC-B substrate under saline conditions. The $\mathrm{pH}$ of the DC-B substrate, although high (alkaline) under fresh conditions as in the previous studies, became substantially less alkaline when exposed to saline conditions. This decrease in $\mathrm{pH}$ corresponded with an increase in the performance of plants grown on the DC-B substrate, such that productivity became more comparable to the other substrates. The results of this study indicate that a major impediment of plant performance in the 
DC-B substrate, high pH, may be ameliorated in saline environments. Furthermore, metal concentrations in substrate interstitial water and plant tissue were found to be low, even though the drill cuttings were subjected to levels of salinity, $\mathrm{pH}$, and Eh that may allow for maximal release of many contaminants (i.e. maximum solubility) at various times during the study. Our results did indicate that substantial amounts of barite (barium sulfate used in drilling fluids) associated with both drill cuttings substrates, and theoretically encapsulated in the DC-B substrate, did dissociate and become available for plant uptake. Plant tissue concentrations of barium were elevated in the plants grown on both the DC-A and DC-B substrates, but fell within ranges reported for agricultural plants such as wheat. Soluble (available) barium levels in the interstitial water always remained at very low levels. Therefore, it appears that as barite dissociated, the available barium was taken up by the plants, which likely incorporated the barium as an insoluble (unavailable) form. The information generated by this study should resolve concerns of direct metal leaching through cation exchange into substrate interstitial water, and has further elucidated the potential use of processed drill cuttings in wetland rehabilitation. We suggest that future research focus on refinements in drilling fluid formulations and the behavior of barite (or alternative drilling fluid additives, such as hematite) under wetland conditions. 

INTRODUCTION 

The coastal wetlands of Louisiana are experiencing a high rate of wetland loss. Estimates of current loss rates are between 65 and $91 \mathrm{~km}^{2} /$ year (Barras et al. 1994; Dunbar et al. 1990). Major reasons for this loss include alteration of the Mississippi River, saltwater intrusion, and canal dredging for oil and gas extraction (Turner 1990). Modification of the Mississippi River, particularly flood protection levees, combined with natural subsidence of this area, has resulted in the loss of the allocthonous sediments needed to nourish and maintain the deltaic marshes. With no substrate input, the marshes subside. As the elevation of a marsh decreases relative to sea level, plants are placed under greater degrees of flooding stress. Eventually, the plants succumb to the stress, the marsh vegetation dies, and the stabilizing effect of the vegetation on the marsh substrate is lost. Erosion then increases and the area converts to open water.

Drill cuttings are oil field waste products that result from drilling excavations. Unprocessed drill cuttings are composed of the parent substrate (earthen materials), and have associated with them the drilling fluids or muds (which may contain additives such as organic thinners, hydroxides, barite, etc.) that are used in the drilling process (Gray and Darley 1980). The type of drilling mud used, and therefore the additives, can vary depending on where the drilling has taken place (Gray and Darley 1980). The drill cuttings investigated in this report were obtained with water-based drilling fluids, which are generally more environmentally benign than oil-based drilling fluids.

Several companies have developed methodologies that allow the drilling additives to be recycled as a cost-reduction technique. Another benefit to this recycling is that once the drilling fluids are removed, a substrate byproduct is created that may be low in toxicity and have potential as a medium for plant growth. Several studies have examined the potential of processed drill cuttings for plant propagation. These studies range in application from 
agricultural usage (Chaineau et al. 1996) to wetland restoration (Kelley and Mendelssohn 1995). Kelley and Mendelssohn (1995) examined the potential for utilizing processed drill cuttings in the restoration of Louisiana wetlands, which are degrading due to a lack of sediment input.

Large amounts of drill cuttings are produced by the oil industry (Kelley and Mendelssohn 1995). In fact, nearly two million tons (dry weight) of this material are currently produced each year (Louisiana Coastal Wetlands Restoration and Conservation Task Force 1993). Kelley and Mendelssohn (1995) suggested that, following amendment with organic material, processed drill cuttings could serve as a medium for plant growth in wetland environments. Studies have also been performed at Southeastern Louisiana University concerning the applicability of processed drill cuttings for wetland creation (DesRoches 1998; Shaffer et al. 1998; Shaffer et al. 1996). In these studies two processed drill cutting types were assessed in terms of vegetation performance and contaminant release in a mesocosm setting. The first processed drill cutting type (hereafter referred to in this study as DC-A) results from centrifugal separation of the cuttings from the drilling mud, while the second (DC-B) results from further processing that encapsulates the cuttings and any remaining drilling fluids within a silica matrix (proprietary information, SWACO, New Orleans).

The studies conducted at Southeastern Louisiana University concerning the safety and suitability of processed drill cuttings for use in wetland restoration have been encouraging (DesRoches 1998; Shaffer et al. 1998; Shaffer et al. 1996). Results from these previous studies indicated that the two types of processed drill cuttings exhibited low toxicity in saline (23-ppt) conditions as tested by mysid shrimp seven-day chronic toxicity trials (DesRoches 1998; Shaffer et al. 1998; Shaffer et al. 1996). These studies also indicated a low probability of heavy metal release to substrate interstitial water (pore water) under freshwater conditions. Plant 
establishment and productivity under freshwater conditions was shown to be comparable among DC-A (drill cuttings centrifugally separated from drilling fluids), dredge spoil, and control substrates (i.e. topsoil). The drill cuttings that underwent further processing to encapsulate the cuttings and remaining drilling fluids (i.e. DC-B) showed low levels of toxicity, but only supported very limited growth of wetland vegetation. The poor response of vegetation grown on DC-B has been attributed to both the high $\mathrm{pH}$ of the interstitial waters of this substrate (mean $\mathrm{pH}=11.1$ ) and the coarse texture of the soil (DesRoches 1998). Nonetheless, the successful colonization of DC-A and the high productivity of vegetation in this substrate indicated that drill cuttings have the capacity to support the growth of wetland vegetation, at least under freshwater conditions.

The studies discussed above demonstrated the potential of processed drill cuttings as a substrate for the restoration of wetlands. However, we decided that investigations on the behavior of processed drill cuttings under various salinity regimes needed to be conducted before truly educated decisions could be made concerning their use in wetland restoration. Most of the wetlands that would potentially benefit from this technique are located in coastal environments and would be exposed to some degree of salinity. Therefore, we conducted the mesocosm study presented in this report.

In this most recent study we examined plant performance and potential metal and ion release from processed drill cuttings under fresh, brackish, saline, and open-ocean salinity regimes. This study addressed concerns that under saline conditions ion exchange may occur that would potentially release metals and other ions from the processed drill cuttings into the interstitial water. This study also reports the response of dominant salt marsh plant species, not previously investigated, when grown on processed drill cuttings. 
Specifically, this study addressed the following questions:

1. Will increased salinity cause heavy metals to migrate from the processed drill cuttings into interstitial water and/or plant biomass?

2. What are the effects of substrate type, hydrologic regime, and salinity on the growth responses of Spartina patens (Ait.) Muhl. (a brackish marsh grass), Spartina alterniflora Loisel. and Spartina cynosuroides (L.) Roth. (dominant salt marsh grasses), and Avicennia germinans (L.) L. (a salt marsh tree)?

3. Do S. alterniflora and $S$. patens exhibit significant intraspecific variation in growth responses to substrate type, hydrologic regime, and salinity regime? 
Materials and Methods 



\section{Experimental Design}

\section{Overview}

The experimental design for this study consisted of four sequential increases in salinity across all treatments of a $4 \times 3 \times 6$ factorial design of four substrates, three hydrologies, and six plant types with two true replicates. The four salinity levels were $0 \mathrm{ppt}, 9 \mathrm{ppt}, 18 \mathrm{ppt}$, and 36 ppt. Each of these salinity levels was maintained for at least a one-month time interval prior to measurements. The four substrates were topsoil (control), products of two different drill cuttings processing techniques referred to hereafter as DC-A and DC-B, and a dredge spoil treatment, which consisted of a 40-cm cap of dredge spoil placed on top of DC-A. The three hydrologic treatments were mesic (continually moist), tidal (daily flooding and draining of water relative to sediment surface), and permanently flooded (always flooded to a depth of $20 \mathrm{~cm}$ ). The tidal treatment was designed to emulate the diurnal tidal range of the northern Gulf Coast of Mexico by ranging from $20 \mathrm{~cm}$ above the soil surface to drainage $10 \mathrm{~cm}$ below the soil surface. Plant species used include Spartina alterniflora (oyster grass), Spartina patens (wiregrass), Spartina cynosuroides (big hogcane), and Avicennia germinans (black mangrove).

\section{Study Facility}

Two years prior to this study, a wetland simulation mesocosm facility was constructed to conduct preliminary investigations of processed drill cuttings as a potential substrate source for wetland restoration under freshwater conditions. This wetland simulation mesocosm facility and its substrates, located at the Southeastern Louisiana University horticultural complex, were used and modified as necessary to perform this experiment. A schematic of the mesocosm design is provided in appendix A-5 for better visualization. 


\section{Substrate Type}

Each treatment mesocosm (200-liter, polyethylene vessel) was filled to approximately $3 / 4$ volume with one of the four test substrates by hand in a cross-classified manner at the time of the original (1996-1998) experiment. As previously mentioned, the same substrates were used for this experiment. This was justified because during the freshwater experiment all substrates were treated in the same fashion and were assigned to the same hydrologic regime used in the present study. The drill cutting materials used in the experiment were generated in Grand Bay, Louisiana (a tidally influenced, intermediate marsh area). All drill cuttings were separated from the drilling fluids, which resulted in the DC-A substrate (processing accomplished by Cameron Corp.). Some of this material was subjected to further processing, resulting in the DC-B substrate (processing accomplished by SWACO Corp.). The further processing of DC-B is proprietary information that is stated to isolate and stabilize the cuttings within a silica matrix. Drill cuttings substrates (DC-A and DC-B) and dredge spoil were transported to the SLU mesocosm facility courtesy of Greenhill Petroleum Company. Topsoil was acquired from a local supplier. All substrates were exposed to the same hydrologic regimes employed in this study during the previous two years of this research. Therefore, substantial time had elapsed to allow these substrates to respond to long-term exposure in simulated wetland environments.

\section{Hydrology Design}

The 200-liter mesocosm treatment vessels (144 total) were networked to four, 3,000-liter reservoirs with each substrate type assigned to a different reservoir. The substrate-specific plumbing design prevents any cross contamination of water from different substrate sources. An overflow drainpipe (3/4-inch diameter PVC) was installed $20 \mathrm{~cm}$ above the soil surface. A controlled-flow drainpipe was also installed, which extended $20 \mathrm{~cm}$ above the soil surface and 
was perforated to a depth of $10 \mathrm{~cm}$ below soil surface. These drainpipes were used to maintain hydrologies as stated below. All overflow drainpipes were left open for the duration of the experiment. Controlled-flow drainpipes were closed for all permanently flooded barrels, except for a two-day period at the inception of each salinity level when they were opened to allow salinities to equilibrate. Controlled-flow pipes were left open for the duration of the experiment for the tidal and mesic hydrologies. Tidal drainlines were connected to substrate-specific electronic valves that could be set by timer to drain for certain intervals, thus creating a tidal effect. All drainpipes were connected to substrate-specific drainlines (1-inch PVC) that emptied into sumps containing Little Giant Big John Submersible sump pumps (Model \#8CMB) that returned water to the substrate-specific reservoirs.

\section{Plant Treatments}

Transplants of S. cynosuroides (big hogcane) were collected from the Bayou Lacombe area, a local brackish marsh. Avicennia germinans (black mangrove) plants were ordered from a horticultural supplier. Three genotypes each of S. patens (wiregrass) and S. alterniflora (oystergrass) were selected from a collection of genotypes that are maintained by Dr. Mark Hester's laboratory at the SLU horticultural complex. These genotypes represented a range of salt tolerance based on his previous research (Hester et al. 1996, Hester et al. 1998). Juncus roemerianus Scheele. (black needle rush) was also collected from the Bayou Lacombe area and was initially included in the study, but the plants persistently showed low survival in all substrates despite several attempts to establish them in the mesocosm. Discussion with other researchers confirmed that this species is highly sensitive to having its roots and rhizomes separated into smaller transplant units. Juncus romerianus can be established in larger sods, but since the soil brought in with a sod would confound direct measurement of substrate-specific 
plant performance, this treatment was omitted and these barrels were treated as a second mudflat (unvegetated). Test plants were transferred into treatment vessels during the period of April 23 to May 5, 1998. Individual plants were rinsed to remove parent soil and then randomly allocated to the appropriate treatment vessels. Plants were maintained under mesic conditions until June 17, 1998, at which time hydrologic treatments were initiated.

\section{Salinity Levels}

Salinity was sequentially increased from $0 \mathrm{ppt}$, to $9 \mathrm{ppt}$, to $18 \mathrm{ppt}$, and then to $36 \mathrm{ppt}$ for all treatment vessels over a one-year period using a commercial aquarium salt (Coralife scientific grade sea salt). The durations of the salinity treatments were four months for the $0 \mathrm{ppt}$ and $9 \mathrm{ppt}$ salinity levels, and two months for the $18 \mathrm{ppt}$ and $36 \mathrm{ppt}$ salinity levels. The increases from 9 ppt to $18 \mathrm{ppt}$ and $18 \mathrm{ppt}$ to $36 \mathrm{ppt}$ were accomplished over a two-week period to allow plants time for acclimation. All treatment vessels were subjected to a 48-hour period with mesic soil conditions and continual water circulation after addition of salt. This ensured that all treatment vessels experienced the same salinity regardless of hydrology. Hydrologies were restored the following day. Salinity levels of each treatment were monitored monthly with both a refractometer and a salinity meter (YSI Model \# 30 salinity/conductivity meter) and adjusted accordingly. Salinity ranges were maintained at $+/-2$ ppt for the 9 -ppt treatment, $+/-2$ ppt for the 18-ppt treatment, and +/- 1 ppt for the 36-ppt treatment. 


\section{Data Collection and Analysis}

\section{Overview}

Data collections were performed at the end of each salinity treatment (Oct. 2-18, 1998 for 0 ppt, Feb. 24-March 3, 1999 for 9 ppt, April 14-28, 1999 for 18 ppt, and July 9-22, 1999 for 36 ppt). Measurements taken consisted of plant photosynthetic response, interstitial water samples ( $\mathrm{pH}$ and elemental analysis), and $\mathrm{Eh}$ at $2 \mathrm{~cm}$ and $15 \mathrm{~cm}$ below the soil surface. Interstitial water samples were filtered and preserved for elemental analysis. Heights and diameters of $A$. germinans were recorded at the conclusion of the experiment. Biomass harvest was performed at the end of the $36 \mathrm{ppt}$ treatment data collection. A subsample of this biomass was used for analysis of metals in plant tissue. A more detailed description of the data collection and analysis methods follows.

\section{Plant Photosynthetic Response}

Plant photosynthetic response was determined using a LICOR® 6400 Photosynthesis System with a built-in light source and $\mathrm{CO}_{2}$ controller. This system provides instantaneous measurements of photosynthetic rate as net $\mathrm{CO}_{2}$ assimilation under selected levels of light and $\mathrm{CO}_{2}$. Measurements were performed on two representative leaves selected from each test plant and then averaged. Reference settings for the photosynthesis system were light levels of 1500 $\mu \mathrm{mol}$ per $\mathrm{m}^{2}$ per second (at or near light-saturated conditions for selected species; see Dai and Wiegert 1997) and $\mathrm{CO}_{2}$ levels of $370 \mu \mathrm{mol}$ per $\mathrm{mol} \mathrm{CO}_{2}$ per $\mathrm{m}^{2}$.

\section{Soil Reduction Potential}

Soil reduction potential (Eh) was monitored in all experimental vessels using a Hanna model HI $9025 \mathrm{pH} / \mathrm{mV}$ meter and brightened platinum redox electrodes. Probes were constructed and calibrated as per Faulkner et al. (1989) and were calibrated and brightened prior 
to each measurement period. A redox probe was placed two centimeters below the soil surface in each vessel, allowed to equilibrate overnight, and redox measurements were taken the following day. A redox probe was then placed $15 \mathrm{~cm}$ below the soil surface and allowed to equilibrate overnight. Readings were recorded the following day.

\section{Interstitial Water Analysis}

Interstitial water $\mathrm{pH}$ was monitored with a Hanna model Hi $9025 \mathrm{pH} / \mathrm{mV}$ meter which was calibrated prior to each measurement period with $\mathrm{pH} 7$ buffer. Measurements were taken by placing the $\mathrm{pH}$ probe into the interstitial well (slotted 3/4 inch PVC pipe extending $10 \mathrm{~cm}$ below soil surface) of each treatment vessel, thus getting a $\mathrm{pH}$ of interstitial water at $10 \mathrm{~cm}$ below the soil surface.

Interstitial water samples for elemental analysis were collected by drawing approximately $20 \mathrm{ml}$ of fluid with a syringe from interstitial water wells. Each sample was then passed through a $2 \mu \mathrm{m}$ syringe filter into an acid-washed scintillation vial. Samples were preserved by adding two drops of concentrated, reagent-grade nitric acid to each sample and then freezing. Prior to analysis the samples were thawed and replicates of higher order interactions were pooled. Samples were then transported to the Louisiana State University Wetland Biogeochemistry Laboratory for analyses. Elemental analysis of samples was performed with a Jarrel-Ash inductively coupled argon plasma mass-optical emission (ICP-OES ATOM COMP SERIES 800) spectrophotometer, except for $\mathrm{Ba}$ and $\mathrm{Hg}$, which were subjected to Cold Vapor Atomic Absorption (CVAA) with a Perkin-Elmer Model 5000 Atomic Absorption Spectrophotometer. Samples were analyzed for the following elements: macrocations (P, K, $\mathrm{Na}, \mathrm{Ca}, \mathrm{Mg}$ ), microcations ( $\mathrm{Fe}, \mathrm{Mn}, \mathrm{Cu}, \mathrm{Zn}, \mathrm{Al}$ ), and heavy metals ( $\mathrm{Cd}, \mathrm{Cr}, \mathrm{Pb}, \mathrm{As}, \mathrm{Ba}, \mathrm{Hg}$ ). It should be noted that the DC-A treatment experienced a large leak during the 18-ppt treatment; therefore, 
interstitial samples were not collected for this treatment. Furthermore, many of the 9-ppt samples were lost due to vial breakage during the thawing period for refiltration. Therefore, these data are presented for qualitative purposes and were not included in the repeated measures analysis of interstitial elements. Because analysis of $\mathrm{Hg}$ requires large volumes of sample (i.e. $\sim 100 \mathrm{ml}$ ), the remainder of the samples after analysis for other elements were pooled by substrate to achieve this volume. Therefore, no replication was possible and these data are presented for qualitative assessment only.

\section{Biomass Measurements}

Plant biomass was harvested at the end of the 36-ppt experimental period. Biomass was separated into aboveground alive, aboveground dead, and belowground partitions and placed into paper bags at harvest. All biomass was dried in a plant-drying oven at $60^{\circ} \mathrm{C}$ for a minimum of three days or until constant weight was achieved. Ten empty bags were taken from the same batch of paper bags used for plant biomass collection and were subjected to the same drying procedure as the biomass bags. The average dry bag weight was then subtracted from the biomass plus bag weight to determine the biomass weight. 


\section{Stem Heights and Diameters}

At the conclusion of the experiment heights of $A$. germinans plants were measured with a meter stick and diameters were measured with digital calipers. All A. germinans appeared similar in height and weight at the inception of the experiment; therefore, the final heights and diameters were deemed appropriate for analysis as dependent variables.

\section{Genotype Analysis}

All treatment vessels that were designated as either S. patens or S. alterniflora were planted with three clones (genotypes) of the appropriate species. Clones were placed equidistant from each other and from vessel design factors that might affect performance (e.g. water inlet, drain valve, etc.). These plants were then subjected to the same measurements as the other plant species. Because of the profuse growth and production of runners by S. alterniflora, discerning genotypes became unreliable towards the conclusion of the experiment. The 36-ppt net $\mathrm{CO}_{2}$ assimilation rates and final biomass partitioning were therefore excluded from the $S$. alterniflora genotypic analyses.

\section{Plant Tissue Analysis}

Subsequent to being weighed, a subsample of dried biomass (approximately $1 \mathrm{~g}$ of stem and leaf ) was obtained from all vegetated test vessels in the mesic and flooded hydrology treatments. Aboveground tissue was ground in a stainless steel Wiley Mill and acid digested as described below. One $\mathrm{g}$ of dry aboveground tissue was placed in $5 \mathrm{ml}$ of concentrated, reagentgrade nitric acid and allowed to partially digest overnight in a fume hood. The samples were then placed in a block heater and heated to $130^{\circ} \mathrm{C}$ for 3 hours. After the samples were removed from the block heater and cooled, they were brought up to $70-\mathrm{ml}$ total volume with distilleddeionized water. Samples were mixed by covering the digestion vials with parafilm and 
inverting 10 times. Samples were allowed to settle and $10 \mathrm{ml}$ of the supernatant from each sample was collected and placed in an acid-washed scintillation vial. The 10-ml samples were then transported to the Louisiana State University Wetland Biochemistry Institute to undergo elemental analysis with a Jarrel-Ash inductively coupled argon plasma mass-optical emission spectrophotometer (ICP-OES ATOM COMP SERIES 800) or Cold Vapor Atomic Absorption (CVAA). Target elements were the same as those chosen for interstitial water analysis (Al, As, $\mathrm{Ba}, \mathrm{Ca}, \mathrm{Cd}, \mathrm{Cr}, \mathrm{Cu}, \mathrm{Fe}, \mathrm{K}, \mathrm{Mg}, \mathrm{Mn}, \mathrm{Na}, \mathrm{Ni}, \mathrm{P}, \mathrm{Pb}$, and $\mathrm{Zn}$ ).

\section{Sediment Analysis}

One $\mathrm{g}$ of substrate was collected from 10 randomly chosen DC-B barrels and dried for digestion and subsequent elemental analysis. Sample analysis proceeded in an identical fashion to the plant tissue analysis stated above.

\section{Statistical Analysis}

All factor analyses were performed using the principle components analysis procedures of SYSTAT version 8.0 (SPSS Inc. 1998). Factor analyses employed a Varimax rotation and minimum eigenvalue of one. All ANOVAs were performed using the general linear model procedures of SYSTAT version 8.0 (SPSS Inc. 1998). Repeated measure ANOVAs, with salinity treated as the repeat factor (Girden 1992), were used to analyze all dependent variables that were measured at each salinity level (soil redox potential, interstitial $\mathrm{pH}$, interstitial elemental concentration, and photosynthetic response). Univariate ANOVAs were employed to test for differences within a time period when a significant interaction with time was detected (Day et al. 1999). As previously mentioned, plants that died were not replaced at the start of each salinity level. In order to prevent confounding of the repeated measures analysis of photosynthetic rates, dead plant photosynthetic rates were entered as 0 for the first salinity level 
in which they were dead and thereafter as missing data for all subsequent salinity levels. This maintained independence among the repeat factors in the repeated measures analysis. Genotypic photosynthetic rates were analyzed as strip-plot (i.e. split-split plot) ANOVAs (Neter et al. 1990). Genotypic final biomass weights were analyzed as split-plot ANOVAs (Neter et al. 1990). Final biomass weights and plant tissue metal concentrations were analyzed using univariate ANOVAs. Final DC-B substrate elemental concentrations were compared with an expected value obtained from previous studies (under non-saline conditions) on this substrate using one sample t-tests. All data were tested for meeting the criteria of parametric analysis. Interstitial element concentration, $\mathrm{pH}$, and redox values for the 0 -ppt treatment were subjected to factor analysis to determine if any variables were behaving in similar fashion. Factor analysis was also performed on the 36-ppt data set for interstitial element concentration, $\mathrm{pH}$, and redox values. Plant tissue elemental concentrations were subjected to a factor analysis to determine similar behavior in elemental concentration. Repeated measures ANOVAs were adjusted for departures from sphericity using the Hunyh-Feldt technique, which compensates for these deviations (Girden 1992). Although total, aboveground, and belowground biomass for species data exhibited mild departures from normality, it was determined acceptable because the ANOVA technique is considered robust with regard to these departures (Neter et al. 1990). 


\section{Results}





\section{Factor Analysis}

Factor analysis indicated that $\mathrm{Pb}, \mathrm{Ni}, \mathrm{As}$, and $\mathrm{Cr}$ behaved in a similar fashion in 0 -ppt interstitial water, 36-ppt interstitial water, final DC-B substrate, and final plant tissue concentrations. Factor scores were not employed for ANOVA calculations because we felt that the identity of all metals should be maintained. However, in all but one case $\mathrm{Pb}, \mathrm{Ni}, \mathrm{As}$, and $\mathrm{Cr}$ behaved in a similar fashion. The only exception was in regard to salinity, where Cr exhibited no significant increase, and $\mathrm{Pb}, \mathrm{Ni}$, and $\mathrm{As}$ all increased, although only slightly, as salinity increased. Factor scores are presented in appendices A-1, A-2, A-3, and A-4.

\section{Elemental Analysis (Substrate)}

Acid-digested substrate concentrations of $\mathrm{Ba}, \mathrm{Zn}, \mathrm{Cr}, \mathrm{Fe}, \mathrm{Mn}, \mathrm{Mg}, \mathrm{Al}, \mathrm{P}$, and $\mathrm{K}$ were significantly lower in the DC-B substrate at the end of the study compared with substrate metal concentrations at the end of year one (Table 1). This indicates migration of metals occurred, to some extent, during the three-year time period between samples. No significant difference was detected with regard to $\mathrm{DC}-\mathrm{B}$ substrate $\mathrm{Ni}, \mathrm{Cu}, \mathrm{Cd}, \mathrm{As}$, and $\mathrm{Pb}$ concentrations, whereas the concentrations of $\mathrm{Ca}$ and $\mathrm{Mg}$ actually increased over time (Table 1).

\section{Elemental Analysis (Interstitial)}

Mercury concentration at each salinity level is presented for qualitative assessment in Table 2. The results of substrate interstitial water analysis on all four test substrates (topsoil, dredge spoil, DC-A, and DC-B) at the end of the 0-ppt and 36-ppt salinity level exposures are presented in Tables 3 and 4 respectively. Because of lost sample data from the 9-ppt salinity level (vial breakage upon freezing) these values were not included in the analysis, but the data is

presented in Table 5 for qualitative evaluation. There was a significant trend toward increases in the concentration of $\mathrm{Ba}, \mathrm{Na}, \mathrm{Pb}, \mathrm{Ni}, \mathrm{As}, \mathrm{Fe}, \mathrm{Ca}, \mathrm{Mg}$, and $\mathrm{P}$ in the 36-ppt salinity level compared 
Table 1. Total potentially extractable (acid-digestion) elemental concentrations in the DCB substrate prior to being subjected to any treatments in 1996 (initial) and at the end of the current study (final). Values are means ( $\mu \mathrm{g} / \mathrm{g}$ soil) plus or minus standard errors in parentheses for final concentration values $(n=10)$.

\begin{tabular}{|c|c|c|c|c|}
\hline Element & $\frac{\text { DC-B (initial) }}{\text { Mean }}$ & $\frac{\text { DC-B (final) }}{\text { Mean }}$ & $\underline{t \text { value }}$ & $\underline{P \text { value }}$ \\
\hline $\mathrm{Ba}$ & 1310.47 & 779.7 & -66944.8 & $<0.001$ \\
\hline $\mathrm{Cu}$ & 58.070 & $\begin{array}{l}57.567 \\
(3.531)\end{array}$ & -0.143 & 0.890 \\
\hline $\mathrm{Zn}$ & 61.860 & $\begin{array}{l}54.082 \\
(1.386)\end{array}$ & -5.480 & $<0.001$ \\
\hline $\mathrm{Cd}$ & 2.490 & $\begin{array}{l}1.939 \\
(0.251)\end{array}$ & -2.199 & 0.055 \\
\hline $\mathrm{Pb}$ & 0.000 & $\begin{array}{l}1.063 \\
(1.063)\end{array}$ & 1.000 & 0.346 \\
\hline $\mathrm{Cr}$ & 32.690 & $\begin{array}{l}15.442 \\
(0.836)\end{array}$ & -20.622 & $<0.001$ \\
\hline $\mathrm{Ni}$ & 26.060 & $\begin{array}{l}26.061 \\
(0.606)\end{array}$ & 0.002 & 0.998 \\
\hline As & 32.180 & $\begin{array}{l}36.756 \\
(7.555)\end{array}$ & 0.606 & 0.560 \\
\hline $\mathrm{Fe}$ & 244418.4 & $\begin{array}{l}23241.96 \\
(29.984)\end{array}$ & -388.069 & $<0.001$ \\
\hline $\mathrm{Mn}$ & 177.660 & $\begin{array}{l}127.58 \\
(2.797)\end{array}$ & -17.904 & $<0.001$ \\
\hline $\mathrm{Ca}$ & 78576.98 & $\begin{array}{l}89382.6 \\
(2606.5)\end{array}$ & 4.146 & 0.003 \\
\hline $\mathrm{Mg}$ & 17507.53 & $\begin{array}{l}19569.8 \\
(586.3)\end{array}$ & 3.517 & 0.007 \\
\hline $\mathrm{P}$ & 692.44 & $\begin{array}{l}838.63 \\
(32.449)\end{array}$ & -1446.572 & $<0.001$ \\
\hline Al & 68546.59 & $\begin{array}{l}34730.5 \\
(766.239)\end{array}$ & -44.133 & $<0.001$ \\
\hline $\mathrm{K}$ & 1462.36 & $\begin{array}{l}1078.33 \\
(34.16)\end{array}$ & -11.242 & $<0.001$ \\
\hline
\end{tabular}


Table 2. Mercury concentration in interstitial water $(\mu \mathrm{g} / \mathrm{g})$ pooled by substrate (across hydrology and species; $\mathrm{n}=12$ ) at the $0 \mathrm{ppt}, 9 \mathrm{ppt}$, and $36 \mathrm{ppt}$ salinity levels.

\begin{tabular}{lllll} 
Salinity & \multicolumn{5}{c}{ Substrate } \\
& Topsoil & Dredge & DC-A & DC-B \\
& 0.140 & 1.140 & 1.210 & 0.030 \\
$0 \mathrm{ppt}$ & 0.570 & 0.620 & 5.610 \\
$9 \mathrm{ppt}$ & 1.390 & 0.570 & & \\
$36 \mathrm{ppt}$ & 0.650 & 1.940 & 1.720 & 0.460
\end{tabular}


Table 3. Results of elemental analysis of substrate interstitial water at the end of the 0-ppt salinity level. Values are mean and maximum concentrations $(\mu \mathrm{g} / \mathrm{g})$ plus or minus standard error in parentheses $(\mathrm{n}=36)$.

Element

Substrate

$\begin{array}{llll}\text { Topsoil } & \text { Dredge } & \text { DC-A } & \text { DC-B } \\ \text { Mean Max. } & \text { Mean Max. } & \text { Mean Max. } & \text { Mean Max. }\end{array}$

\begin{tabular}{|c|c|c|c|c|c|}
\hline $\mathrm{Ba}$ & $\begin{array}{l}0.041 \\
(0.013)\end{array}$ & 0.202 & $\begin{array}{ll}0.069 & 0.166 \\
(0.009)\end{array}$ & $\begin{array}{l}0.115 \quad 0.251 \\
(0.016)\end{array}$ & $\begin{array}{l}0.100 \quad 0.238 \\
(0.012)\end{array}$ \\
\hline $\mathrm{Cu}$ & $\begin{array}{l}0.016 \\
(0.005)\end{array}$ & 0.062 & $\begin{array}{l}0.030 \quad 0.101 \\
(0.008)\end{array}$ & $\begin{array}{l}0.0190 .074 \\
(0.006)\end{array}$ & $\begin{array}{l}0.011 \quad 0.062 \\
(0.005)\end{array}$ \\
\hline $\mathrm{Zn}$ & $\begin{array}{l}0.171 \\
(0.059)\end{array}$ & 0.949 & $\begin{array}{l}0.104 \quad 0.351 \\
(0.021)\end{array}$ & $\begin{array}{l}0.160 \quad 0.026 \\
(0.381)\end{array}$ & $\begin{array}{l}0.123 \quad 0.635 \\
(0.032)\end{array}$ \\
\hline $\mathrm{Cd}$ & $\begin{array}{l}0.000 \\
(0.000)\end{array}$ & 0.000 & $\begin{array}{l}0.006 \quad 0.062 \\
(0.062)\end{array}$ & $\begin{array}{l}0.0060 .003 \\
(0.048)\end{array}$ & $\begin{array}{l}0.0040 .033 \\
(0.002)\end{array}$ \\
\hline $\mathrm{Pb}$ & $\begin{array}{l}0.015 \\
(0.005)\end{array}$ & 0.050 & $\begin{array}{l}0.0370 .148 \\
(0.011)\end{array}$ & $\begin{array}{l}0.0100 .056 \\
(0.004)\end{array}$ & $\begin{array}{l}0.006 \quad 0.066 \\
(0.004)\end{array}$ \\
\hline $\mathrm{Cr}$ & $\begin{array}{l}0.000 \\
(0.000)\end{array}$ & 0.000 & $\begin{array}{l}0.003 \quad 0.030 \\
(0.002)\end{array}$ & $\begin{array}{l}0.0010 .012 \\
(0.001)\end{array}$ & $\begin{array}{l}0.000 \quad 0.000 \\
(0.000)\end{array}$ \\
\hline $\mathrm{Ni}$ & $\begin{array}{l}0.000 \\
(0.000)\end{array}$ & 0.000 & $\begin{array}{l}0.006 \quad 0.060 \\
(0.004)\end{array}$ & $\begin{array}{l}0.000 \quad 0.000 \\
(0.000)\end{array}$ & $\begin{array}{l}0.000 \quad 0.000 \\
(0.000)\end{array}$ \\
\hline As & $\begin{array}{l}0.004 \\
(0.004)\end{array}$ & 0.076 & $\begin{array}{l}0.0230 .130 \\
(0.010)\end{array}$ & $\begin{array}{l}0.000 \quad 0.000 \\
(0.000)\end{array}$ & $\begin{array}{l}0.000 \quad 0.000 \\
(0.000)\end{array}$ \\
\hline $\mathrm{Fe}$ & $\begin{array}{l}1.453 \\
(0.429)\end{array}$ & 6.090 & $\begin{array}{l}0.873 \quad 3.807 \\
(0.204)\end{array}$ & $\begin{array}{l}1.9000 .657 \\
(10.35)\end{array}$ & $\begin{array}{l}0.304 \quad 2.374 \\
(0.135)\end{array}$ \\
\hline $\mathrm{Mn}$ & $\begin{array}{l}0.271 \\
(0.092)\end{array}$ & 1.489 & $\begin{array}{l}0.0640 .333 \\
(0.023)\end{array}$ & $\begin{array}{l}0.130 \quad 0.881 \\
(0.054)\end{array}$ & $\begin{array}{l}0.014 \quad 0.147 \\
(0.009)\end{array}$ \\
\hline $\mathrm{Ca}$ & $\begin{array}{l}15.912 \\
(2.217)\end{array}$ & 33.49 & $\begin{array}{l}52.72448 .9 \\
(25.21)\end{array}$ & $\begin{array}{l}22.30 \quad 62.22 \\
(3.478)\end{array}$ & $\begin{array}{l}16.6079 .63 \\
(4.792)\end{array}$ \\
\hline $\mathrm{Mg}$ & $\begin{array}{l}5.164 \\
(0.627)\end{array}$ & 9.190 & $\begin{array}{ll}31.48 & 193.7 \\
(13.46)\end{array}$ & $\begin{array}{l}12.7984 .76 \\
(4.325)\end{array}$ & $\begin{array}{l}4.00850 .17 \\
(2.860)\end{array}$ \\
\hline$P$ & $\begin{array}{l}4.645 \\
(1.628)\end{array}$ & 29.37 & $\begin{array}{l}1.6753 .910 \\
(0.214)\end{array}$ & $\begin{array}{l}1.7734 .000 \\
(0.268)\end{array}$ & $\begin{array}{ll}0.311 & 1.270 \\
(0.085)\end{array}$ \\
\hline $\mathrm{Al}$ & $\begin{array}{l}1.004 \\
(0.236)\end{array}$ & 3.680 & $\begin{array}{l}1.005 \quad 3.040 \\
(0.165)\end{array}$ & $\begin{array}{l}1.1534 .480 \\
(0.304)\end{array}$ & $\begin{array}{l}8.03420 .99 \\
(1.228)\end{array}$ \\
\hline K & $\begin{array}{l}5.127 \\
(1.197)\end{array}$ & 15.31 & $\begin{array}{l}16.27448 .33 \\
(2.698)\end{array}$ & $\begin{array}{l}13.9241 .47 \\
(1.744)\end{array}$ & $\begin{array}{l}22.7950 .65 \\
(2.777)\end{array}$ \\
\hline $\mathrm{Na}$ & $\begin{array}{l}138.2 \\
(10.82)\end{array}$ & 269.8 & $\begin{array}{l}274.1796 .9 \\
(42.72)\end{array}$ & $\begin{array}{l}276.0699 .3 \\
(30.33)\end{array}$ & $\begin{array}{ll}274.0 & 508.7 \\
(27.08) & \end{array}$ \\
\hline
\end{tabular}


Table 4. Results of elemental analysis of substrate interstitial water at the end of the 9-ppt salinity level. Values are mean and maximum concentrations $(\mu \mathrm{g} / \mathrm{g})$ plus or minus standard error in parenthesis $(n=36)$.

Element

Substrate

\begin{tabular}{|c|c|c|c|c|c|}
\hline & Topso & & Dredge & DC-A & DC-B \\
\hline & Mean & Max. & Mean Max. & Mean Max. & Mean Max. \\
\hline $\mathrm{Ba}$ & $\begin{array}{l}0.020 \\
(0.004)\end{array}$ & 0.024 & $\begin{array}{l}0.046 \quad 0.134 \\
(0.004)\end{array}$ & $\begin{array}{l}0.0740 .195 \\
(0.014)\end{array}$ & $\begin{array}{l}0.0550 .131 \\
(0.009)\end{array}$ \\
\hline $\mathrm{Cu}$ & $\begin{array}{l}0.020 \\
(0.020)\end{array}$ & 0.059 & $\begin{array}{l}0.0350 .135 \\
(0.010)\end{array}$ & $\begin{array}{l}0.000 \quad 0.000 \\
(0.000)\end{array}$ & $\begin{array}{l}0.0350 .082 \\
(0.007)\end{array}$ \\
\hline $\mathrm{Zn}$ & $\begin{array}{l}0.092 \\
(0.022)\end{array}$ & 0.134 & $\begin{array}{l}0.81512 .78 \\
(0.748)\end{array}$ & $\begin{array}{l}0.2202 .186 \\
(0.179)\end{array}$ & $\begin{array}{l}0.0620 .146 \\
(0.010)\end{array}$ \\
\hline $\mathrm{Cd}$ & $\begin{array}{l}0.007 \\
(0.007)\end{array}$ & 0.020 & $\begin{array}{ll}0.626 & 10.54 \\
(0.626) & \end{array}$ & $\begin{array}{l}0.0020 .023 \\
(0.002)\end{array}$ & $\begin{array}{l}0.000 \quad 0.000 \\
(0.000)\end{array}$ \\
\hline $\mathrm{Pb}$ & $\begin{array}{l}0.040 \\
(0.021)\end{array}$ & 0.070 & $\begin{array}{l}18.10307 .0 \\
(18.05)\end{array}$ & $\begin{array}{ll}0.000 & 0.000 \\
0.000 & \end{array}$ & $\begin{array}{l}0.016 \quad 0.059 \\
(0.006)\end{array}$ \\
\hline $\mathrm{Cr}$ & $\begin{array}{l}0.004 \\
(0.004)\end{array}$ & 0.011 & $\begin{array}{l}13.490 .809 \\
(0.793)\end{array}$ & $\begin{array}{l}0.0020 .018 \\
(0.002)\end{array}$ & $\begin{array}{l}0.0050 .016 \\
(0.002)\end{array}$ \\
\hline $\mathrm{Ni}$ & $\begin{array}{l}0.000 \\
(0.000)\end{array}$ & 0.000 & $\begin{array}{l}0.0220 .080 \\
(0.007)\end{array}$ & $\begin{array}{l}0.003 \quad 0.037 \\
(0.003)\end{array}$ & $\begin{array}{l}0.003 \quad 0.042 \\
(0.003)\end{array}$ \\
\hline As & $\begin{array}{l}0.000 \\
(0.000)\end{array}$ & 0.000 & $\begin{array}{l}0.089 \quad 0.706 \\
(0.040)\end{array}$ & $\begin{array}{l}0.005 \quad 0.063 \\
(0.005)\end{array}$ & $\begin{array}{l}0.000 \quad 0.000 \\
(0.000)\end{array}$ \\
\hline $\mathrm{Fe}$ & $\begin{array}{l}8.392 \\
(7.192)\end{array}$ & 22.781 & $\begin{array}{l}1.7764 .898 \\
(0.385)\end{array}$ & $\begin{array}{l}1.2053 .744 \\
(0.257)\end{array}$ & $\begin{array}{l}0.7121 .354 \\
(0.119)\end{array}$ \\
\hline Mn & $\begin{array}{l}6.999 \\
(3.712)\end{array}$ & 13.52 & $\begin{array}{l}3.002 \quad 36.67 \\
(2.144)\end{array}$ & 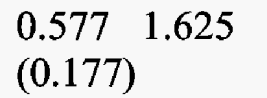 & $\begin{array}{l}0.003 \quad 0.027 \\
(0.002)\end{array}$ \\
\hline $\mathrm{Ca}$ & $\begin{array}{l}171.3 \\
(55.25)\end{array}$ & 281.26 & $\begin{array}{l}254.2748 .2 \\
(45.52)\end{array}$ & $\begin{array}{l}118.9196 .5 \\
(13.70)\end{array}$ & $\begin{array}{l}126.0 \quad 294.2 \\
(22.51)\end{array}$ \\
\hline $\mathrm{Mg}$ & $\begin{array}{l}92.21 \\
(9.079)\end{array}$ & 107.30 & $\begin{array}{l}138.4229 .6 \\
(14.38)\end{array}$ & $\begin{array}{l}76.46138 .2 \\
(8.148)\end{array}$ & $\begin{array}{l}34.93105 .3 \\
(10.12)\end{array}$ \\
\hline $\mathbf{P}$ & $\begin{array}{l}0.610 \\
(0.295)\end{array}$ & 1.200 & $\begin{array}{l}0.548 \quad 1.450 \\
(0.074)\end{array}$ & $\begin{array}{l}0.406 \quad 0.820 \\
(0.061)\end{array}$ & $\begin{array}{l}0.2540 .570 \\
(0.037)\end{array}$ \\
\hline Al & $\begin{array}{l}1.543 \\
(1.543)\end{array}$ & 0.459 & $\begin{array}{l}1.8998 .290 \\
(0.425)\end{array}$ & $\begin{array}{l}0.908 \quad 1.450 \\
(0.096)\end{array}$ & $\begin{array}{l}1.4752 .740 \\
(0.212)\end{array}$ \\
\hline K & $\begin{array}{l}72.583 \\
(32.39\end{array}$ & 136.80 & $\begin{array}{l}75.66160 .3 \\
(9.292)\end{array}$ & $\begin{array}{l}54.98 \quad 86.99 \\
(4.472)\end{array}$ & $\begin{array}{l}74.97 \quad 117.8 \\
(5.346)\end{array}$ \\
\hline $\mathrm{Na}$ & $\begin{array}{l}800.27 \\
(139.8)\end{array}$ & 1075.0 & $\begin{array}{l}883.21041 \\
(34.38)\end{array}$ & $\begin{array}{l}746.1 \quad 1010.0 \\
(39.18)\end{array}$ & $\begin{array}{l}709.6 \quad 943.5 \\
(34.84)\end{array}$ \\
\hline
\end{tabular}


Table 5. Results of elemental analysis of substrate interstitial water at the end of the 36-ppt salinity level. Values are mean and maximum concentrations $(\mu \mathrm{g} / \mathrm{g})$ plus or minus standard error in parenthesis $(n=36)$.

Element

Substrate

\begin{tabular}{|c|c|c|c|}
\hline Tor & Dredge & DC-A & DC-B \\
\hline
\end{tabular}

\begin{tabular}{|c|c|c|c|c|}
\hline $\begin{array}{l}1.003 \quad 1 \\
(0.081)\end{array}$ & 1.730 & $\begin{array}{l}1.1324 .860 \\
(0.276)\end{array}$ & $\begin{array}{l}0.9312 .500 \\
(0.126)\end{array}$ & $\begin{array}{l}1.3463 .290 \\
(3.290)\end{array}$ \\
\hline $\begin{array}{l}0.1830 \\
(1.137)\end{array}$ & 0.070 & $\begin{array}{l}0.827 \quad 13.745 \\
(0.760)\end{array}$ & $\begin{array}{ll}0.281 & 1.784 \\
(0.123) & \end{array}$ & $\begin{array}{l}0.108 \quad 0.595 \\
(0.040)\end{array}$ \\
\hline $\begin{array}{l}0.0620 \\
(0.019)\end{array}$ & 0.246 & $\begin{array}{l}0.474 \quad 7.780 \\
(0.430)\end{array}$ & $\begin{array}{l}0.1100 .576 \\
(0.034)\end{array}$ & $\begin{array}{l}0.0200 .198 \\
(0.012)\end{array}$ \\
\hline $\begin{array}{l}0.025 \quad 0 \\
(0.017)\end{array}$ & 0.301 & $\begin{array}{l}0.017 \quad 0.268 \\
(0.015)\end{array}$ & $\begin{array}{l}0.0150 .084 \\
(0.005)\end{array}$ & $\begin{array}{l}0.000 \quad 0.002 \\
(0.000)\end{array}$ \\
\hline $\begin{array}{l}0.1150 \\
(0.054)\end{array}$ & 0.855 & $\begin{array}{l}0.090 \quad 0.249 \\
(0.022)\end{array}$ & $\begin{array}{l}0.264 \quad 2.307 \\
(0.135)\end{array}$ & $\begin{array}{l}0.140 \quad 0.510 \\
(0.038)\end{array}$ \\
\hline $\begin{array}{l}0.006 \quad 0 \\
(0.004)\end{array}$ & 0.071 & $\begin{array}{l}0.0010 .018 \\
(0.001)\end{array}$ & $\begin{array}{l}0.0130 .134 \\
(0.008)\end{array}$ & $\begin{array}{l}0.0010 .025 \\
(0.001)\end{array}$ \\
\hline $\begin{array}{l}0.000 \quad 0 \\
(0.000)\end{array}$ & 0.000 & $\begin{array}{l}0.010 \quad 0.046 \\
(0.003)\end{array}$ & $\begin{array}{l}0.056 \quad 0.360 \\
(0.021)\end{array}$ & $\begin{array}{l}0.030 \quad 0.043 \\
(0.020)\end{array}$ \\
\hline $\begin{array}{l}0.062 \quad 0 \\
(0.021)\end{array}$ & 0.302 & $\begin{array}{l}0.050 \quad 0.190 \\
(0.016)\end{array}$ & $\begin{array}{l}0.172 \quad 1.500 \\
(0.083)\end{array}$ & $\begin{array}{l}0.0230 .236 \\
(0.015)\end{array}$ \\
\hline $\begin{array}{l}19.87 \\
(6.040)\end{array}$ & 77.82 & $\begin{array}{l}7.838 \quad 30.89 \\
(2.508)\end{array}$ & $\begin{array}{l}16.8966 .80 \\
(4.888)\end{array}$ & $\begin{array}{l}0.2970 .850 \\
(0.053)\end{array}$ \\
\hline $\begin{array}{l}0.064 \quad 0 \\
(0.027)\end{array}$ & 0.330 & $\begin{array}{l}6.22818 .97 \\
(1.478)\end{array}$ & $\begin{array}{ll}3.647 & 12.54 \\
(0.888)\end{array}$ & $\begin{array}{l}0.0640 .330 \\
(0.027)\end{array}$ \\
\hline $\begin{array}{l}331.9 \quad 8 \\
(64.20)\end{array}$ & 829.7 & $\begin{array}{l}405.9 \quad 1678 \\
(103.6)\end{array}$ & $\begin{array}{l}690.4 \quad 1837 \\
(112.7)\end{array}$ & $\begin{array}{l}668.21466 \\
(117.5)\end{array}$ \\
\hline $\begin{array}{ll}190.2 & 1 \\
(74.38) & \end{array}$ & 1102 & $\begin{array}{l}169.9848 .0 \\
(74.31)\end{array}$ & $\begin{array}{l}295.11136 \\
(75.81)\end{array}$ & $\begin{array}{l}0.000 \quad 0.000 \\
(0.000)\end{array}$ \\
\hline $\begin{array}{l}1.6108 \\
(0.680)\end{array}$ & 8.960 & $\begin{array}{ll}0.201 & 1.660 \\
(0.126) & \end{array}$ & $\begin{array}{l}0.348 \quad 1.990 \\
(0.157)\end{array}$ & $\begin{array}{l}0.0330 .190 \\
(0.013)\end{array}$ \\
\hline $\begin{array}{l}22.21 \quad 3 \\
(22.21)\end{array}$ & 347.0 & $\begin{array}{l}0.2362 .450 \\
(0.156)\end{array}$ & $\begin{array}{l}1.4847 .510 \\
(0.452)\end{array}$ & $\begin{array}{l}0.078 \quad 0.660 \\
(0.046)\end{array}$ \\
\hline $\begin{array}{l}53.40 \quad 5 \\
(34.93)\end{array}$ & 546.1 & $\begin{array}{l}79.46 \quad 695.1 \\
(50.35)\end{array}$ & $\begin{array}{l}116.51408 \\
(78.67)\end{array}$ & $\begin{array}{l}53.40 \quad 546.1 \\
(34.93)\end{array}$ \\
\hline $\begin{array}{ll}9658 & 1 \\
(979.3) & \end{array}$ & 18536 & $\begin{array}{l}274.1796 .9 \\
(42.72)\end{array}$ & $\begin{array}{l}981620316 \\
(969.0)\end{array}$ & $\begin{array}{l}849613566 \\
(712.6)\end{array}$ \\
\hline
\end{tabular}


with the 0-ppt salinity level (Tables 3 and 4; all $\mathrm{P}<0.05$ ). This trend was the most pronounced in DC-A and topsoil, and the least pronounced in DC-B. In fact, a significant interaction of salinity by substrate was present for both $\mathrm{Mg}$ and $\mathrm{Ni}$, because although all other substrates showed an increase in these elements, their concentrations in DC-B were below detection throughout the study.

A significant interaction between salinity and substrate existed for $\mathrm{Ca}$ concentrations (Fig. $1 ; \mathrm{F}=7.504, \mathrm{P}<0.001$ ). This can be explained by the large increase of $\mathrm{Ca}$ concentration in the DC-A and DC-B substrates in the 36-ppt salinity treatment. A significant interaction was also detected between salinity and hydrology at the 0-ppt salinity level, in which Ca concentrations were highest under mesic conditions, whereas at the 36-ppt salinity level, Ca concentrations were highest under tidal conditions (Fig. 2; $\mathrm{F}=14.336, \mathrm{P}<0.001$ ). A significant species and salinity interaction was detected because $S$. cynosuroides had the highest interstitial Ca levels at the 0-ppt salinity level, whereas other species (especially $S$. alterniflora) displayed increased interstitial water $\mathrm{Ca}$ concentrations at the 36-ppt salinity level (Fig. $3 \mathrm{~F}=6.325, \mathrm{P}<$ 0.001). In general, the main effect of salinity level on interstitial water Ca concentrations was consistent across all interactions, with $\mathrm{Ca}$ concentration being greater at the 36-ppt salinity level than at the 0-ppt salinity level.

A significant three-way interaction between salinity, substrate, and hydrology was detected for $\mathrm{Fe}$ concentrations (Fig. 4; $\mathrm{F}=2.679, \mathrm{P}=0.025$ ). This was likely due to the increase in the $\mathrm{Fe}$ concentrations of the topsoil substrate under all hydrologies, whereas dredge spoil and DC-A Fe concentrations increased only under flooded and tidal conditions, and DC-B Fe concentrations did not change. This interaction limits the interpretation of the main effect of 


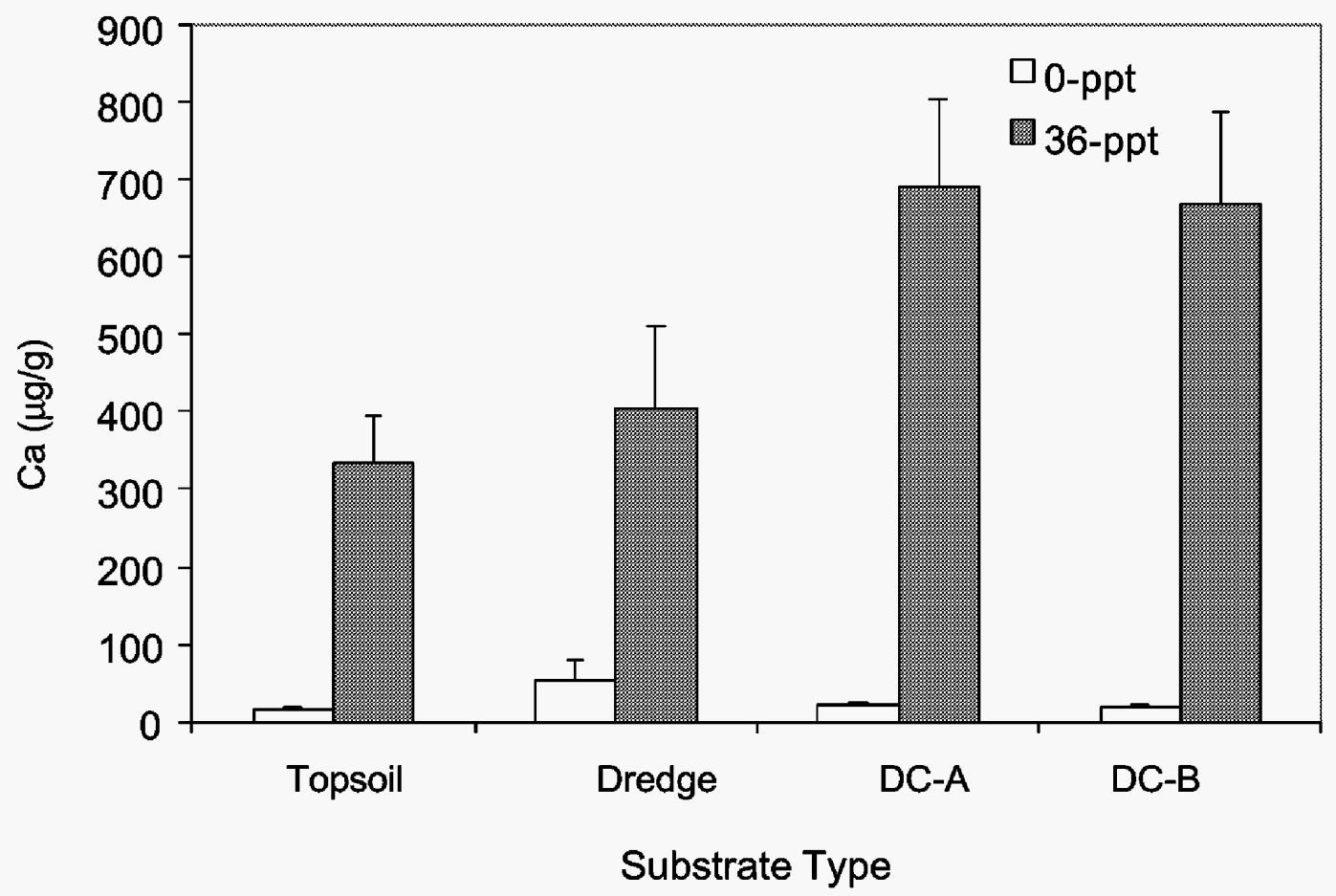

Fig. 1. The effect of salinity level and substrate type on interstitial Ca concentration (mean $+/$ - standard error) averaged across hydrologic regime and plant species. 


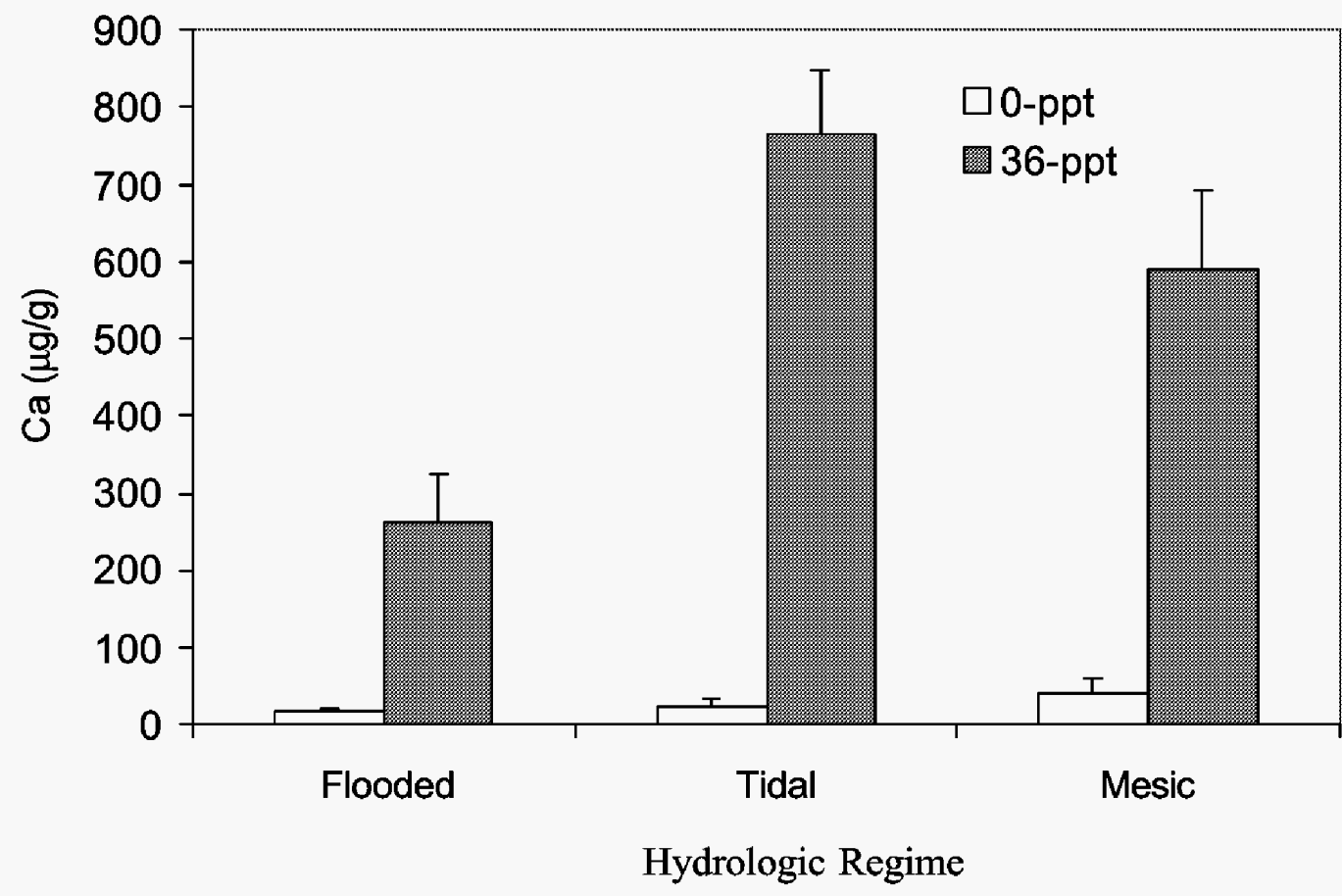

Fig. 2. The effect of salinity level and hydrologic regime on substrate interstitial water $\mathrm{Ca}$ concentration (mean $+/$ - standard error) averaged across substrate type and plant species. 


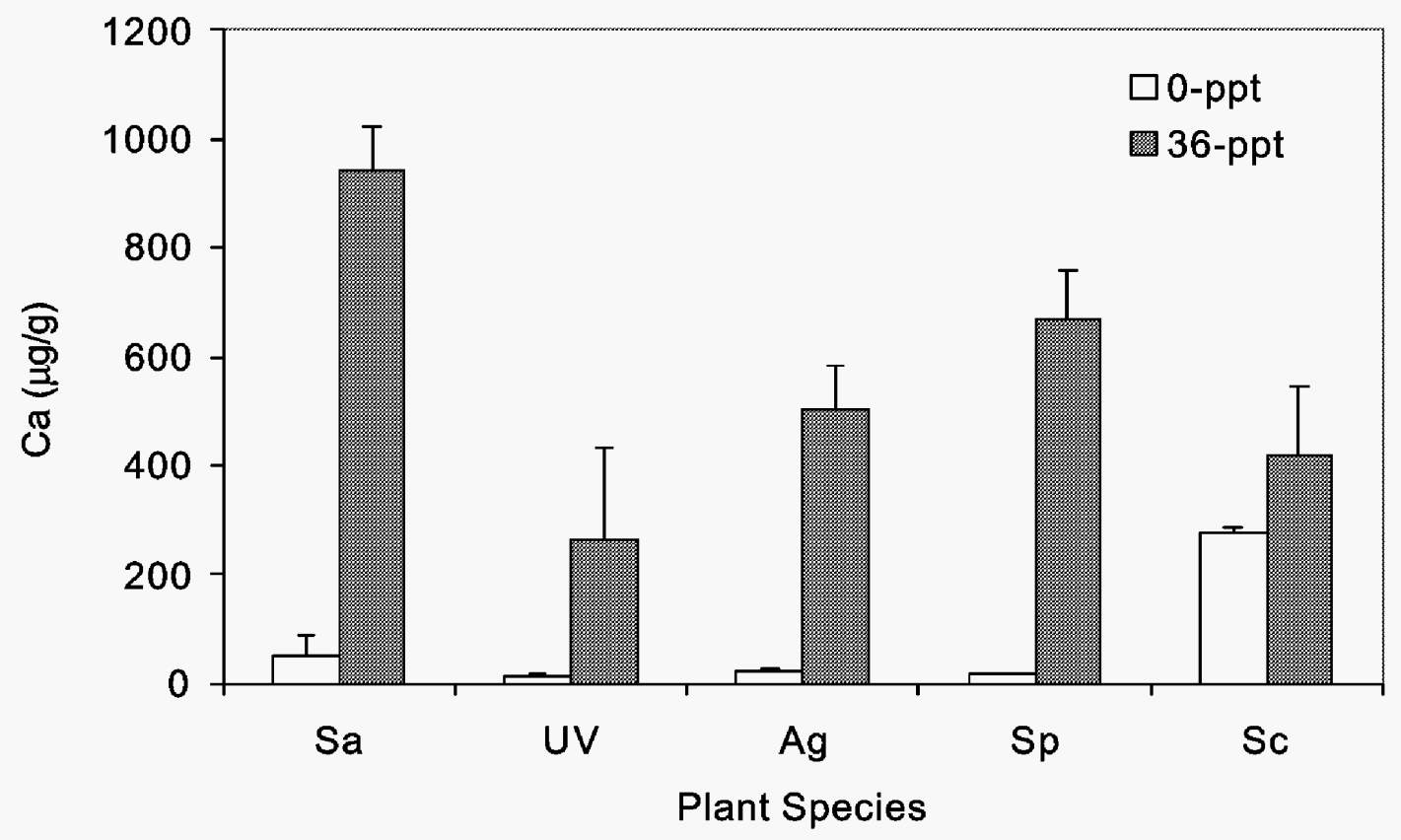

Fig. 3. The effect of salinity level and plant species on interstitial Ca concentration (mean $+/-$ standard error) averaged across substrate type and hydrologic regime. Species abbreviations are as follows: $\mathrm{Sa}=S$. alterniflora, $\mathrm{Ag}=A$. germinans, $\mathrm{Sp}=S$. patens, $\mathrm{Sc}=$ S. cynosuroides. 

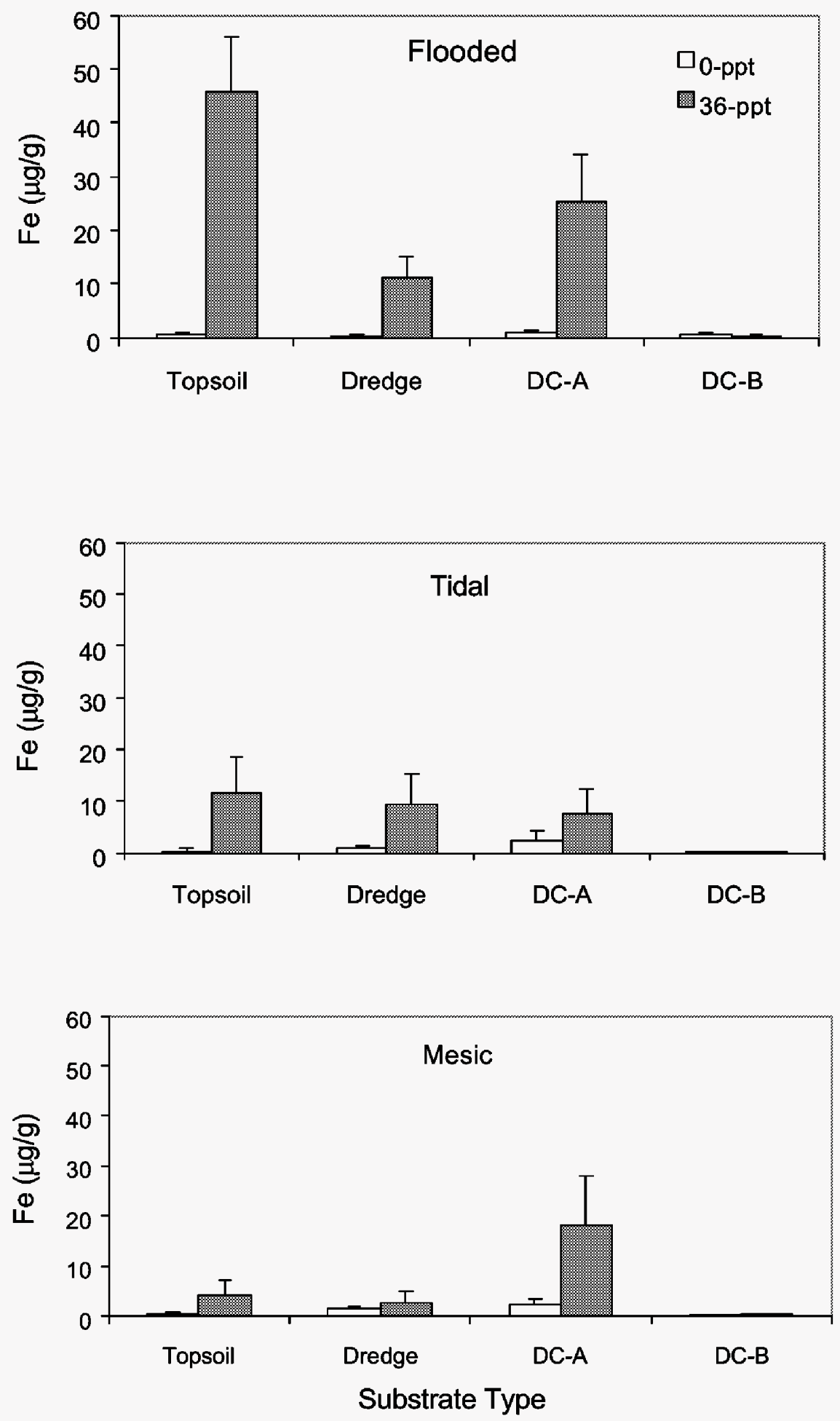

Fig. 4. The effect of salinity level, substrate type, and hydrologic regime on interstitial Fe concentration (mean $+/$ - standard error) averaged across plant species. 
salinity, but the interactions between salinity and substrate $(\mathrm{F}=5.425, \mathrm{P}=0.003)$, and salinity and hydrology $(\mathrm{F}=7.407, \mathrm{P}=0.002)$, are consistent with the explanation of the three-way interaction. A significant three-way interaction between salinity, substrate, and hydrology was also detected for $\mathrm{Mg}$ concentrations (Fig. $5 ; \mathrm{F}=2.330, \mathrm{P}=0.046$ ). This can best be explained by the high concentration of $\mathrm{Mg}$ in dredge spoil under the flooded, 36-ppt salinity level. This explanation is consistent with a significant salinity by hydrology interaction $(\mathrm{F}=11.406, \mathrm{P}<$ 0.001). A significant interaction also occurred between salinity and substrate (Fig. 6; $F=7.338$, $\mathrm{P}<0.001)$. This interaction appears to be due to the large increase in $\mathrm{Mg}$ concentration in all substrates except DC-B under increasing salinity levels.

\section{Elemental Analysis (Vegetation)}

Results of elemental analysis of acid-digested plant material are presented in Table 6. No significant effects of substrate, hydrology, species, or the interactions thereof were detected in plant tissue concentrations of $\mathrm{Cu}, \mathrm{Zn}, \mathrm{Cd}, \mathrm{Pb}, \mathrm{Cr}, \mathrm{Ni}, \mathrm{As}, \mathrm{Ca}, \mathrm{Al}, \mathrm{K}$, or $\mathrm{Na}$. Plants grown in the DC-A and DC-B substrates had higher concentrations of Ba than those grown in topsoil or dredge spoil (Fig. 7; Contrast $\mathrm{F}=6.318, \mathrm{P}=0.020$ ). Plants grown in the DC-B substrate had significantly lower Mn levels than plants grown on any other substrates (Fig. 8; Contrast F= 7.351, $\mathrm{P}=0.014)$. Avicennia germinans had significantly higher $\mathrm{Mg}$ concentrations than all other species regardless of substrate (Fig. 9; Contrast $\mathrm{F}=8.774, \mathrm{P}=0.008$ ). Plants grown on topsoil had a greater concentration of $\mathrm{P}$ than those grown on other substrates (Fig. 10; Contrast $\mathrm{F}=12.601$, $\mathrm{P}=0.002)$. 

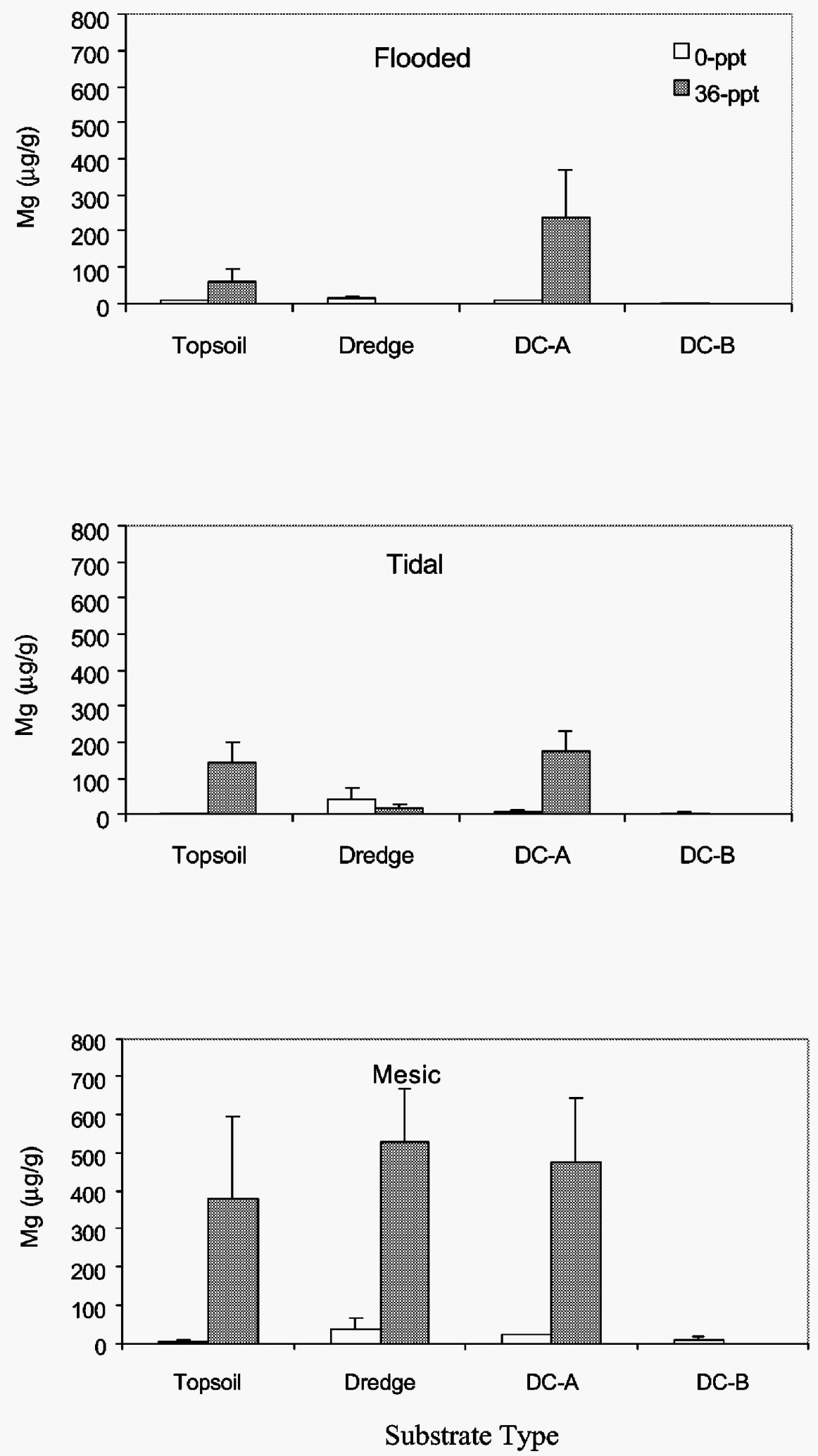

Fig. 5. The effect of salinity level, substrate type, and hydrologic regime on interstitial $\mathrm{Mg}$ concentration (mean $+/$ - standard error) averaged across plant species. 


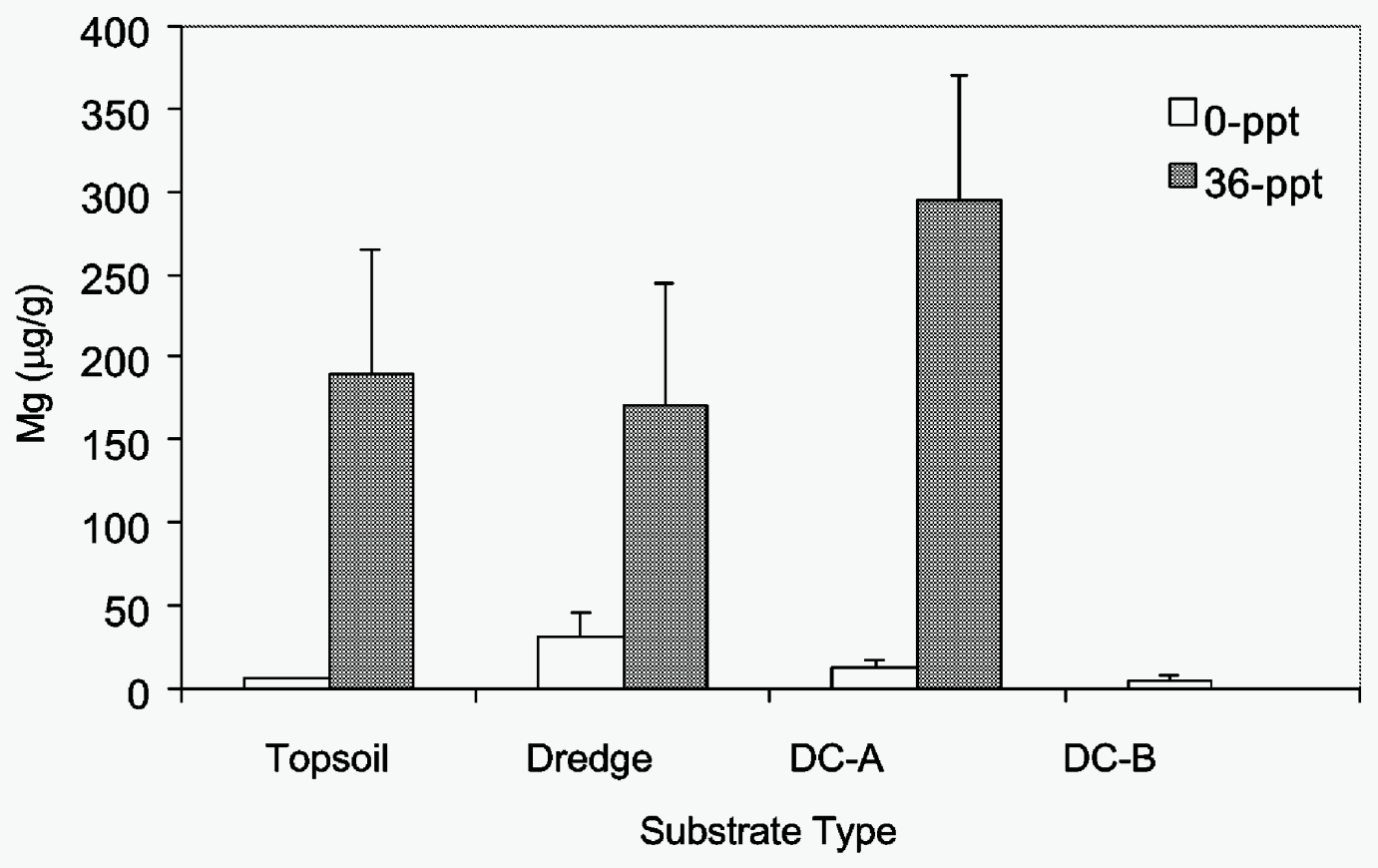

Fig. 6. The effect of salinity level and substrate type on interstitial $\mathrm{Mg}$ concentration (mean $+/-$ standard error) averaged across hydrologic regime and plant species. 
Table 6. Results of elemental analysis of aboveground plant tissue at the end of the 0-ppt salinity level. Values are mean and maximum concentrations $(\mu \mathrm{g} / \mathrm{g})$, plus or minus standard error in parentheses $(n=36)$.

Element

Substrate

\begin{tabular}{|c|c|}
\hline \multicolumn{2}{|c|}{ Topsoil } \\
\hline Mean & Max. \\
\hline $\begin{array}{l}6.030 \\
(1.656)\end{array}$ & 15.60 \\
\hline $\begin{array}{l}1.780 \\
(1.780)\end{array}$ & 12.46 \\
\hline $\begin{array}{l}32.98 \\
(13.41)\end{array}$ & 111.8 \\
\hline
\end{tabular}

Dredge

DC-A

DC-B

Mean Max.

Mean Max.

Mean Max.

$\mathrm{Ba}$

6.72825 .66

$22.15 \quad 45.08$

20.2566 .99

$\mathrm{Cu}$

(2.724)

(6.917)

(7.803)

2.3808 .820

$\begin{array}{ll}2.310 & 6.370\end{array}$

(1.267)

(1.142)

$5.504 \quad 27.30$

33.5497 .790

$20.24 \quad 39.48$

(10.60)

(4.169)

$0.219 \quad 1.750$

$\begin{array}{lll}0.220 & 1.540\end{array}$

(0.220)

(0.219)

$0.000 \quad 0.000$

$(0.000)$

$\begin{array}{lll}0.250 & 0.910\end{array}$

(3.485)

29.62863 .70

(6.039)

$0.411 \quad 1.750$

(0.280)

$0.814 \quad 3.570$

(0.536)

$0.429 \quad 1.470$

(0.162)

(0.298)

$\begin{array}{lll}\mathrm{Ni} & 1.470 & 10.29\end{array}$

(1.470)

(0.216)

$1.250 \quad 4.830$

(0.813)

(0.270)

$0.971 \quad 4.830$

(0.660)

$0.560 \quad 1.890$

$1.689 \quad 6.020$

(0.862)

$3.280 \quad 10.57$

$(0.281)$

$3.089 \quad 15.260$

(1.645)

(1.896)

$202.5 \quad 513.3$

$\begin{array}{lll}186.0 & 377.4\end{array}$

(39.04)

$223.0 \quad 635.9$

(78.25)

5026.410170 .

(1027.8)

1957.64137 .0

(427.6)

$925.7 \quad 1416.8$

(128.9)

$86.4 \quad 156.8$

(20.76)

5611.47994 .0

(821.0)

20094. 41692

(3197.0)

$1.146 \quad 4.690$

(0.751)

$1.645 \quad 7.770$

(1.100)

$124.8 \quad 259.1$

(26.53)

$62.97 \quad 199.6$

(21.55)

6361.713508

(1327.6)

1457.32398 .2

(284.6)

$613.6 \quad 1086.4$

(100.0)

$\begin{array}{lll}131.6 & 435.4\end{array}$

(60.91)

4665.19758 .0

(1140.9)

2285041692.

(4099.2) 


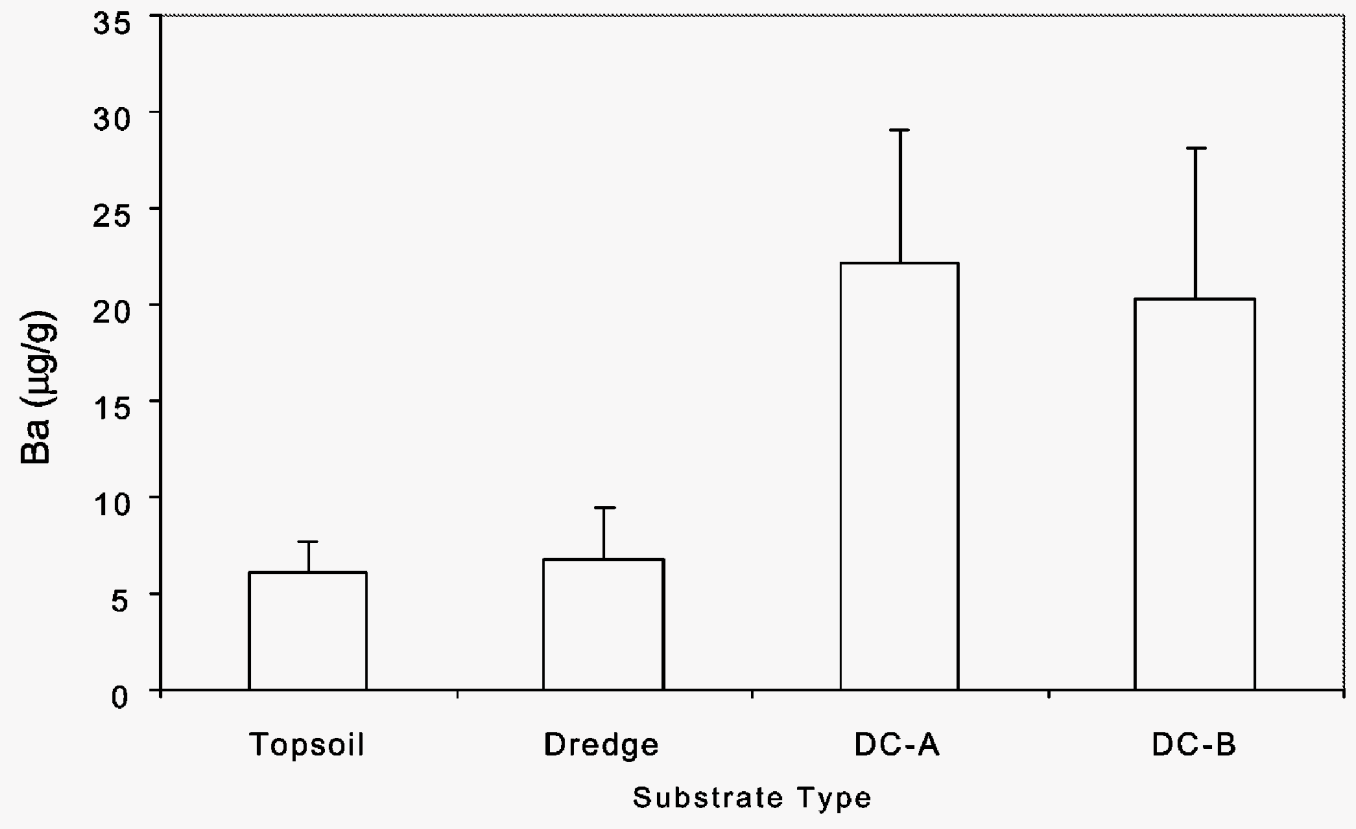

Fig. 7. The effect of substrate type on Ba concentration (mean $+/$ - standard error) in plant tissue averaged across hydrologic regime and plant species. 


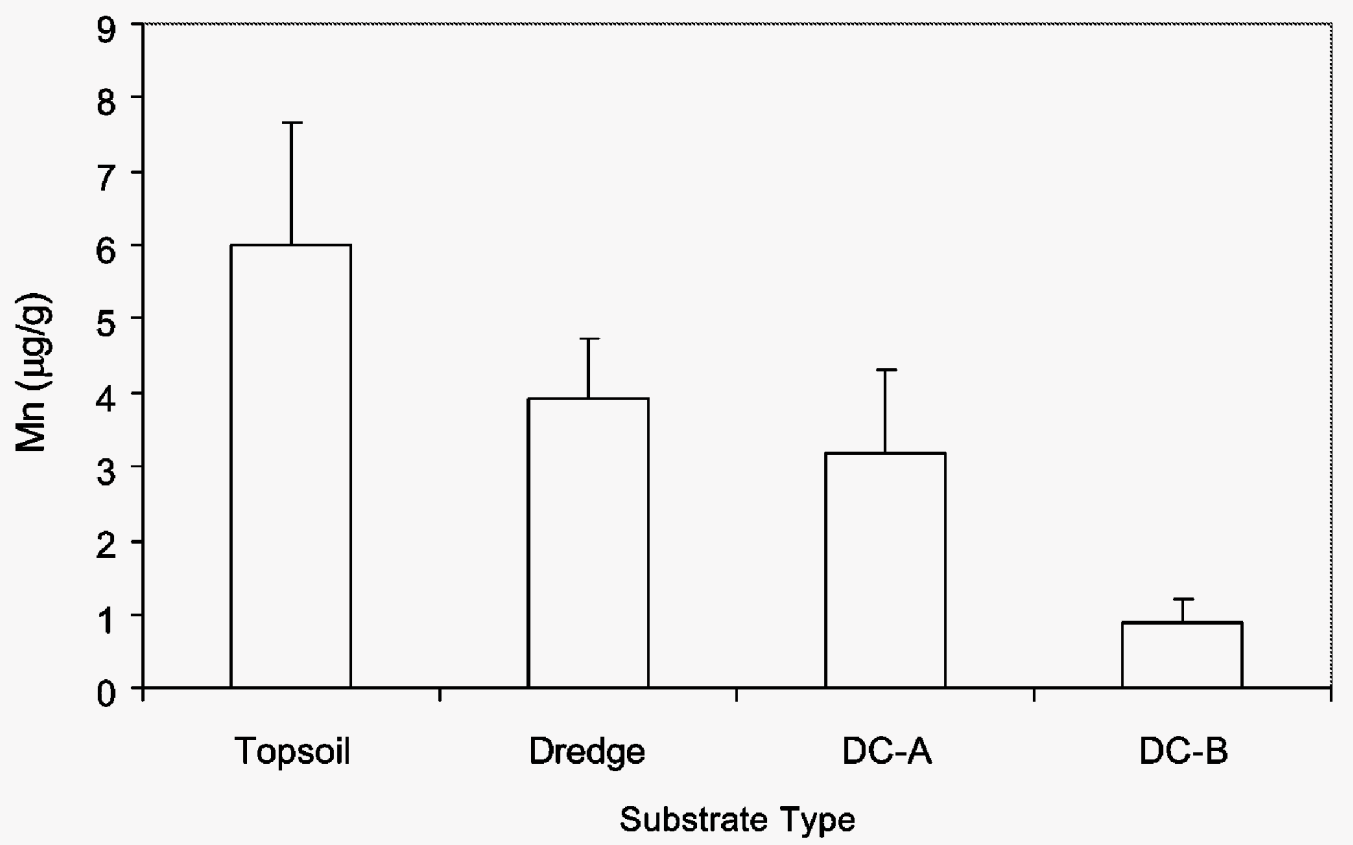

Fig. 8. The effect of substrate type on Mn concentration (mean $+/$ - standard error) in plant tissue averaged across hydrologic regime and plant species. 


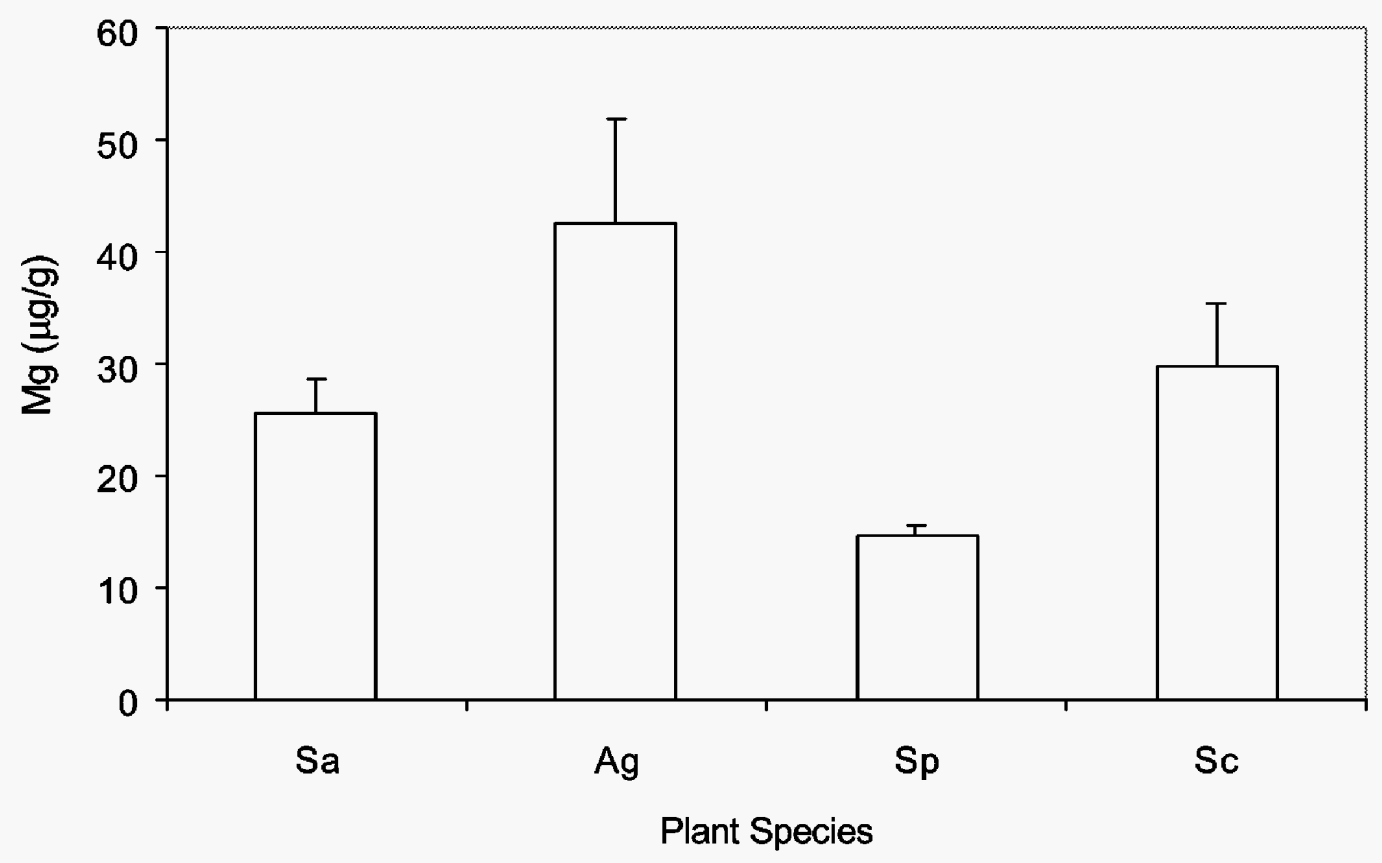

Fig. 9. The effect of plant species on $\mathrm{Mg}$ concentration (mean $+/-$ standard error) in plant tissue averaged across substrate type and hydrologic regime. Species abbreviations are as follows: $\mathrm{Sa}=S$. alterniflora, $\mathrm{Ag}=A$. germinans, $\mathrm{Sp}=S$. patens, $\mathrm{Sc}=S$.

cynosuroides. 


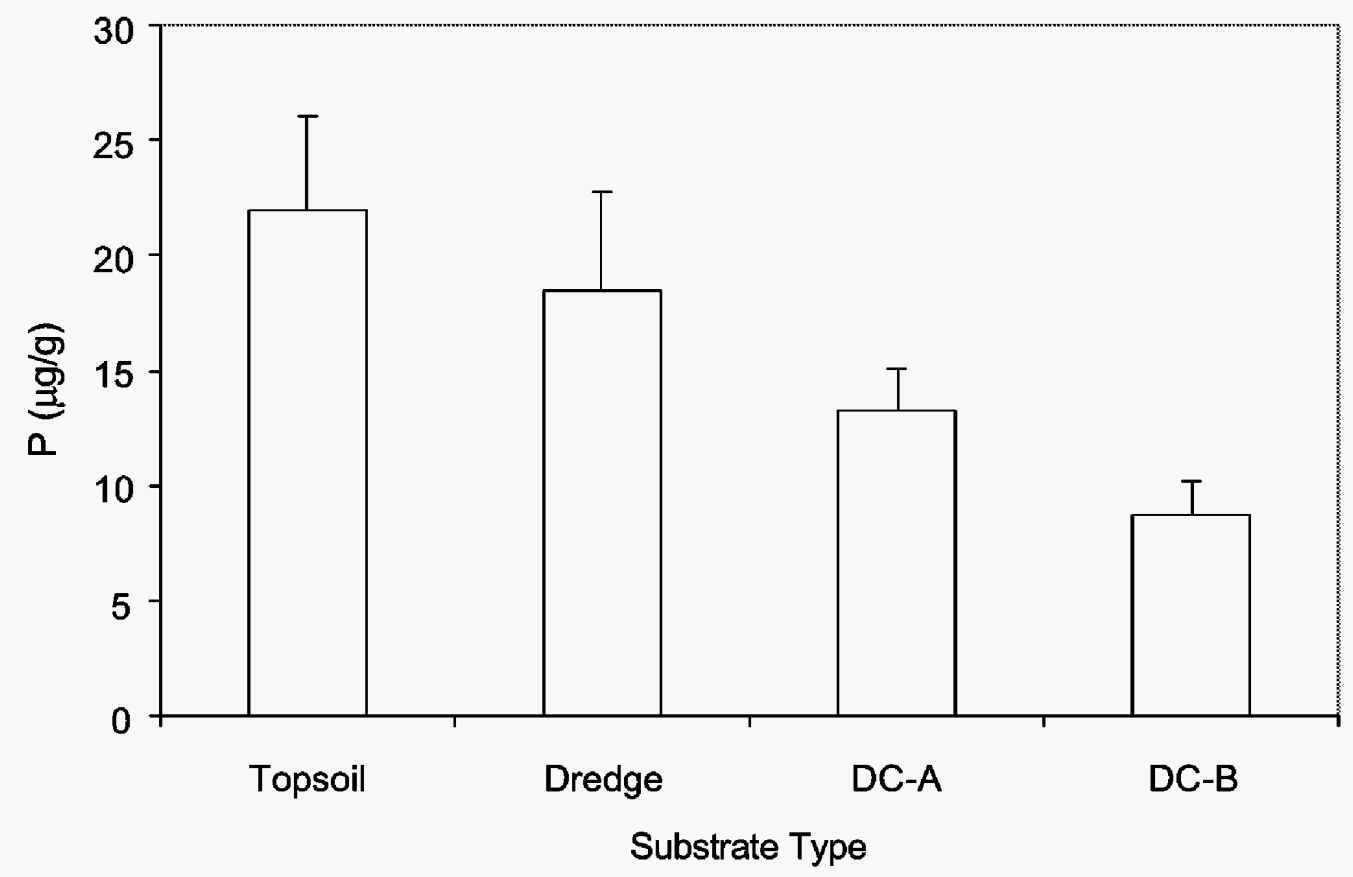

Fig. 10. The effect of substrate type on $P$ concentration (mean $+/$ - standard error) in plant tissue averaged across hydrologic regime and plant species. 


\section{Soil Redox Potential}

Soil redox potential at $1 \mathrm{~cm}$ depth displayed a highly significant decrease with increasing salinity levels (Fig. 11; $\mathrm{F}=108.741, \mathrm{P}<0.001$ ). Soil redox potential at the $15 \mathrm{~cm}$ depth also became more reduced as salinity level increased, although this trend was not as pronounced (Fig. $11 ; \mathrm{F}=177.368, \mathrm{P}<0.001$ ). A marginally significant salinity level by hydrologic regime interaction was detected, probably because at the 18-ppt salinity level the mesic hydrology did not display the usual increase in redox potential relative to the flooded hydrology. (Fig. 12; F= $2.276, \mathrm{P}=0.038$ ). Although the mean soil redox for each treatment was greater than $-100 \mathrm{mV}$, values in the range of sulfide formation and methanogenisis (less than $-100 \mathrm{mV}$ ) were detected for each substrate type for all soil depths and salinity levels measured. This is important to note because most metals are maximally soluble and have the greatest potential for bioaccumulation at redox potentials less than $-100 \mathrm{mV}$ (see discussion).

\section{pH}

There was a significant effect of salinity level and substrate type on $\mathrm{pH}$ (Fig. 13; $\mathrm{F}=\mathrm{P}<$ 0.001). As the prior studies indicated, the $\mathrm{pH}$ of $\mathrm{DC}-\mathrm{B}$ was highly elevated compared to the other substrates under freshwater conditions. However, the $\mathrm{pH}$ of DC-B was significantly lower under all saline treatments than under freshwater conditions (Fig. 13; Contrast $\mathrm{F}=59.882, \mathrm{P}<$ 0.001). Under non-saline conditions, the flooded hydrologic regime displayed the highest $\mathrm{pH}$, but this effect disappeared as salinity increased (Fig. 14; $\mathrm{F}=3.936, \mathrm{P}=0.001$ ). 


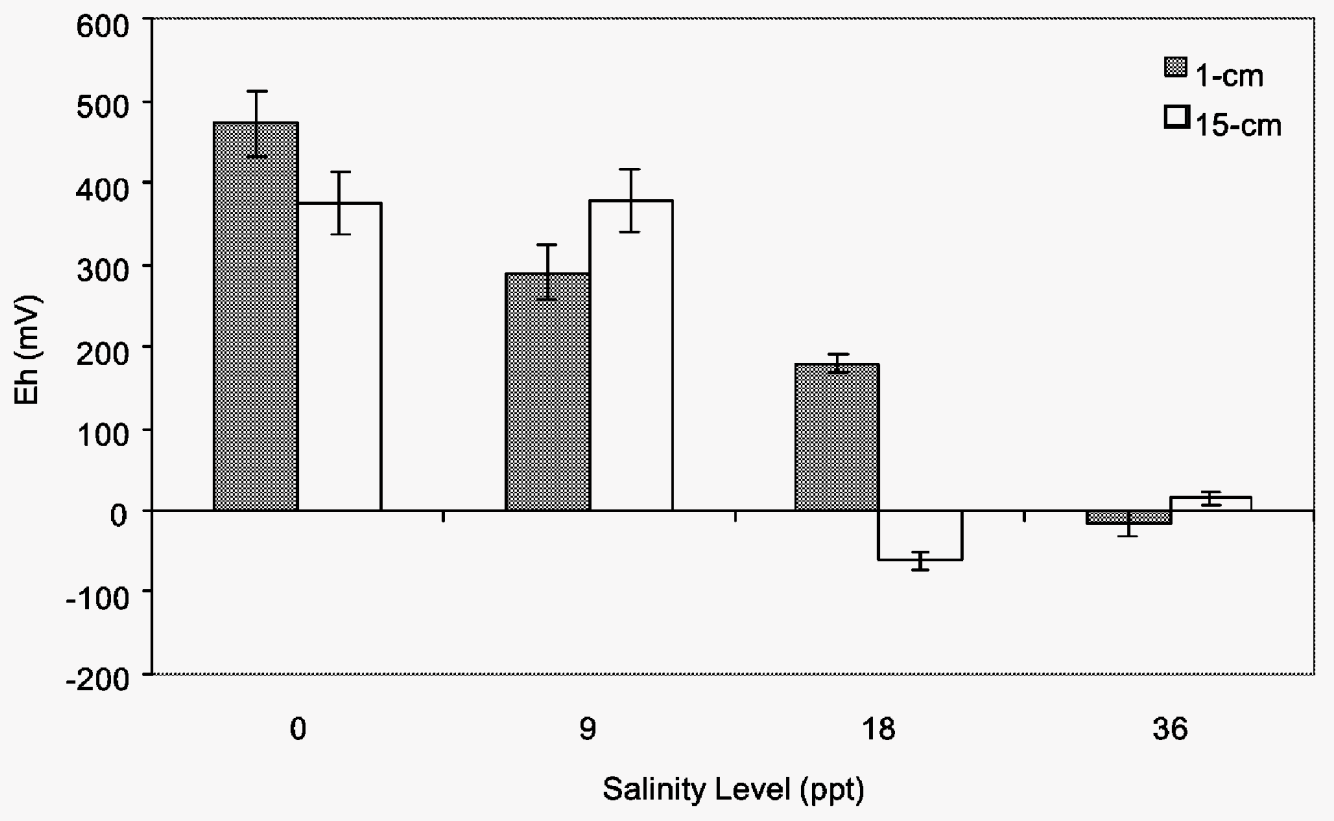

Fig. 11. The effect of salinity level on soil redox potential (mean $+/-$ standard error) at two soil depths (1-m and 15-cm) averaged across substrate type, hydrologic regime, and plant species. 

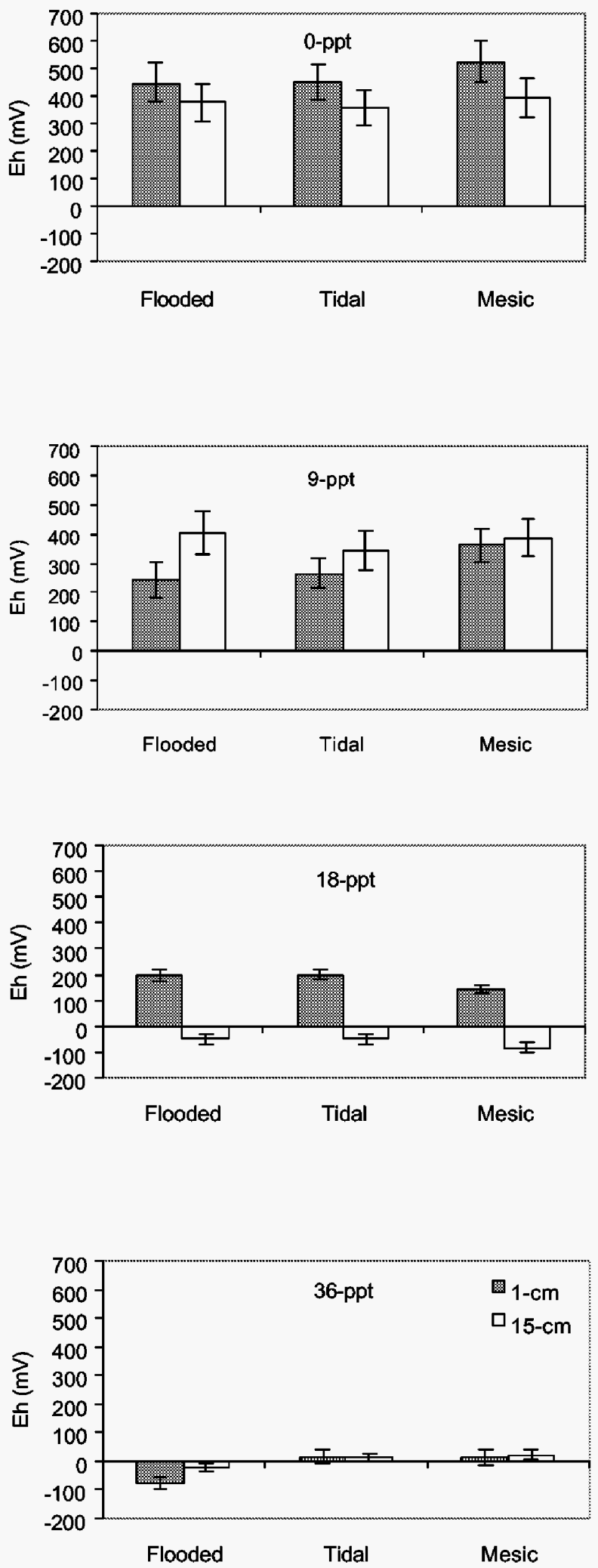

Fig. 12. The effect of hydrologic regime and salinity level on soil redox (mean $+/$ - standard error) averaged across substrate type and plant species. 


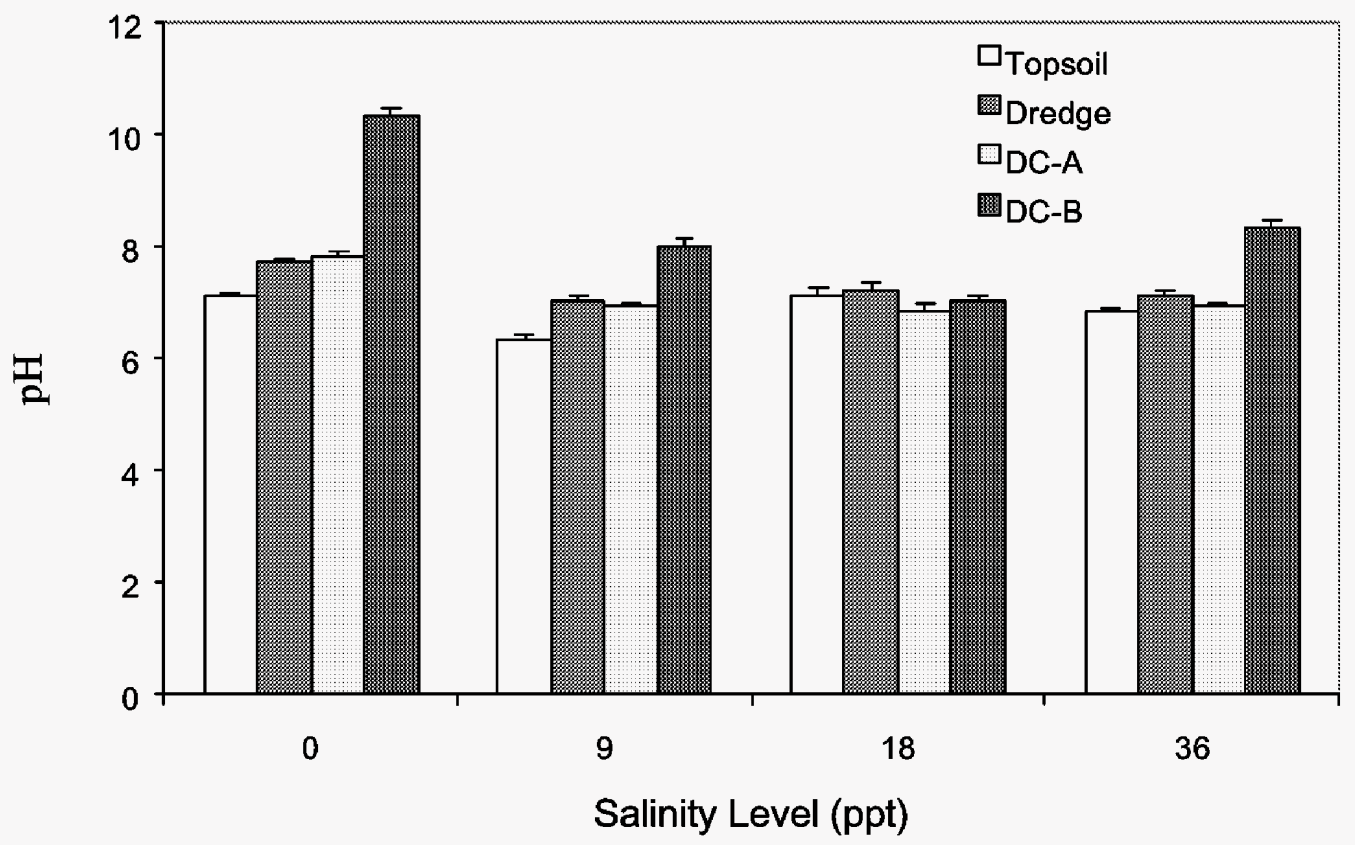

Fig. 13. The effect of salinity level and substrate type on interstitial $\mathrm{pH}$ (mean $+/$ - standard error) averaged across hydrologic regime and plant species. 


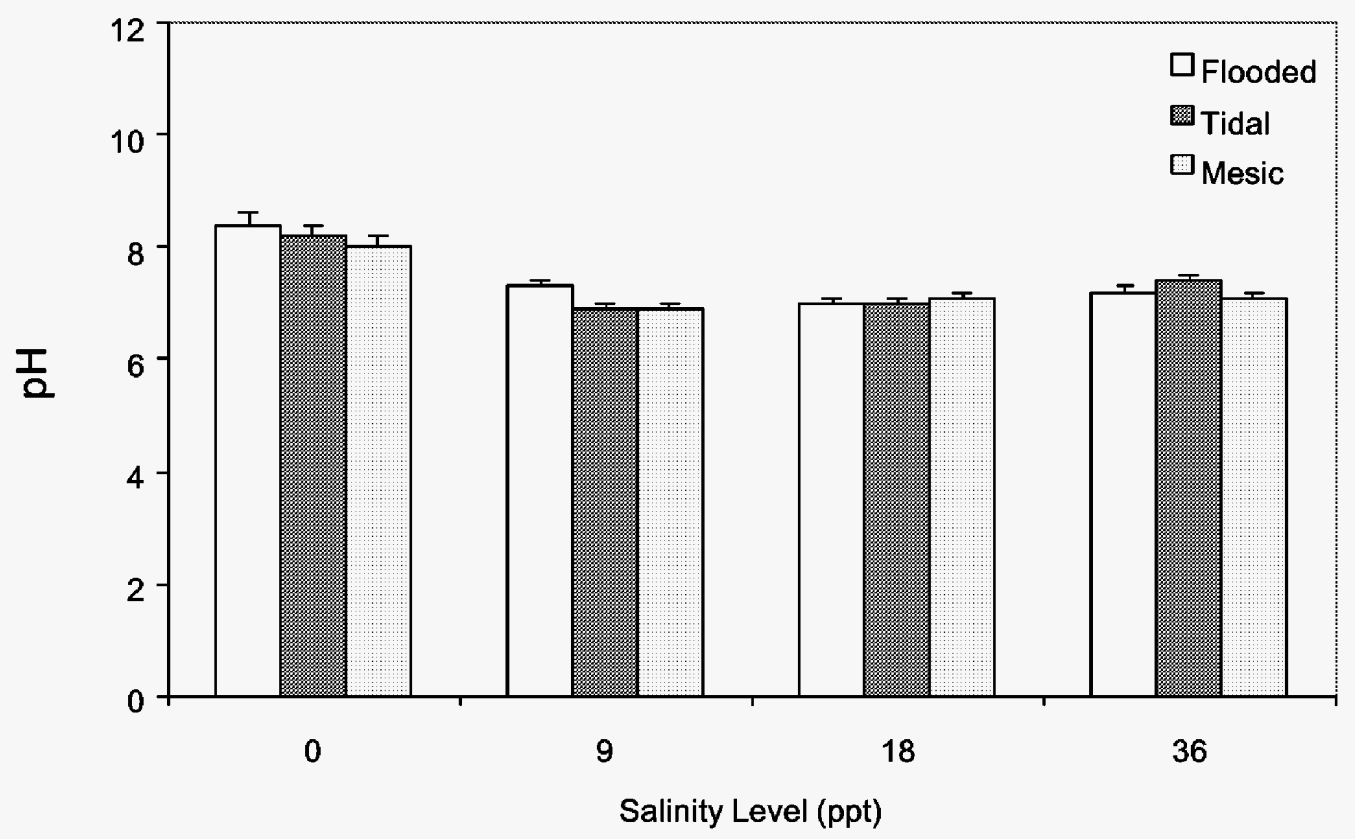

Fig. 14. The effect of salinity level and hydrologic regime on interstitial $\mathrm{pH}$ (mean +/standard error) averaged across hydrologic regime and plant species. 


\section{Photosynthetic Response}

There was a significant effect of salinity level on net $\mathrm{CO}_{2}$ assimilation rate (Fig. 15; $\mathrm{F}=$ 14.434, $\mathrm{P}<0.001$ ). Analysis within salinity levels showed that at the 0 -ppt salinity level, plants had significantly reduced net $\mathrm{CO}_{2}$ assimilation rates when grown in DC-B compared to the other substrates (Fig. 16; Contrast $\mathrm{F}=9.206, \mathrm{P}=0.003$ ). This was probably due to the elevated $\mathrm{pH}$ that DC-B exhibits under freshwater conditions. No significant differences were detected among substrate types at any other salinity level. It is important to note that no significant differences were detected in net $\mathrm{CO}_{2}$ assimilation rates due to substrate type, hydrologic regime, or their interaction under saline conditions. This indicates that plants were performing comparably over time regardless of substrate type and hydrologic regime as long as the $\mathrm{pH}$ was less alkaline than under non-saline conditions. There was no significant effect of hydrologic regime on plant photosynthesis. Overall, net $\mathrm{CO}_{2}$ assimilation rates were greatest in the 9-ppt salinity level.

\section{Total Biomass}

Substrate type, hydrologic regime, and plant species all had marginally significant effects on total plant biomass (Fig. $17 ; \mathrm{F}=1.768, \mathrm{P}=0.05$ ). This was likely driven by the apparent high performance of $S$. cynosuroides under all hydrologies in DC-B, and the high performance of $S$. patens in DC-B under mesic conditions. This limits the interpretation of the main effect of substrate type, but it appears that DC-B total biomass was significantly reduced compared to all other substrates (Fig. 18; Contrast $\mathrm{F}=8.397, \mathrm{P}=0.006$ ). No significant differences were detected among hydrologies in total biomass production. A significant effect of species was discerned (Fig. 19; $\mathrm{F}=7.860, \mathrm{P}=0.001$ ). This was likely driven by the reduced biomass of $A$. germinans compared to the other plant species and probably simply reflects the difference between herbaceous versus woody growth forms. 



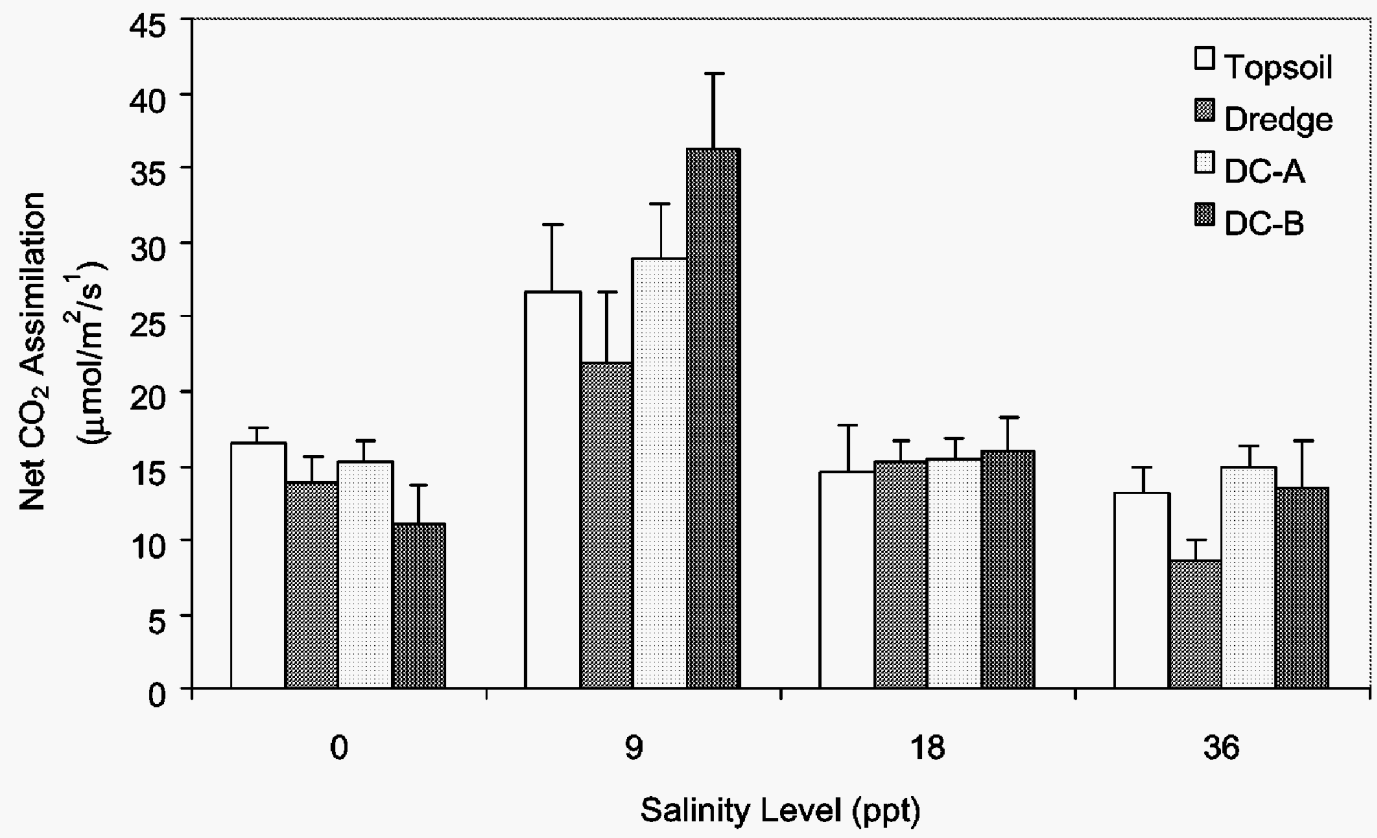

Fig. 16. The effect of salinity level and substrate type on net $\mathrm{CO}_{2}$ assimilation rate (mean $+/-$ standard error) averaged across hydrologic regime, and plant species. 

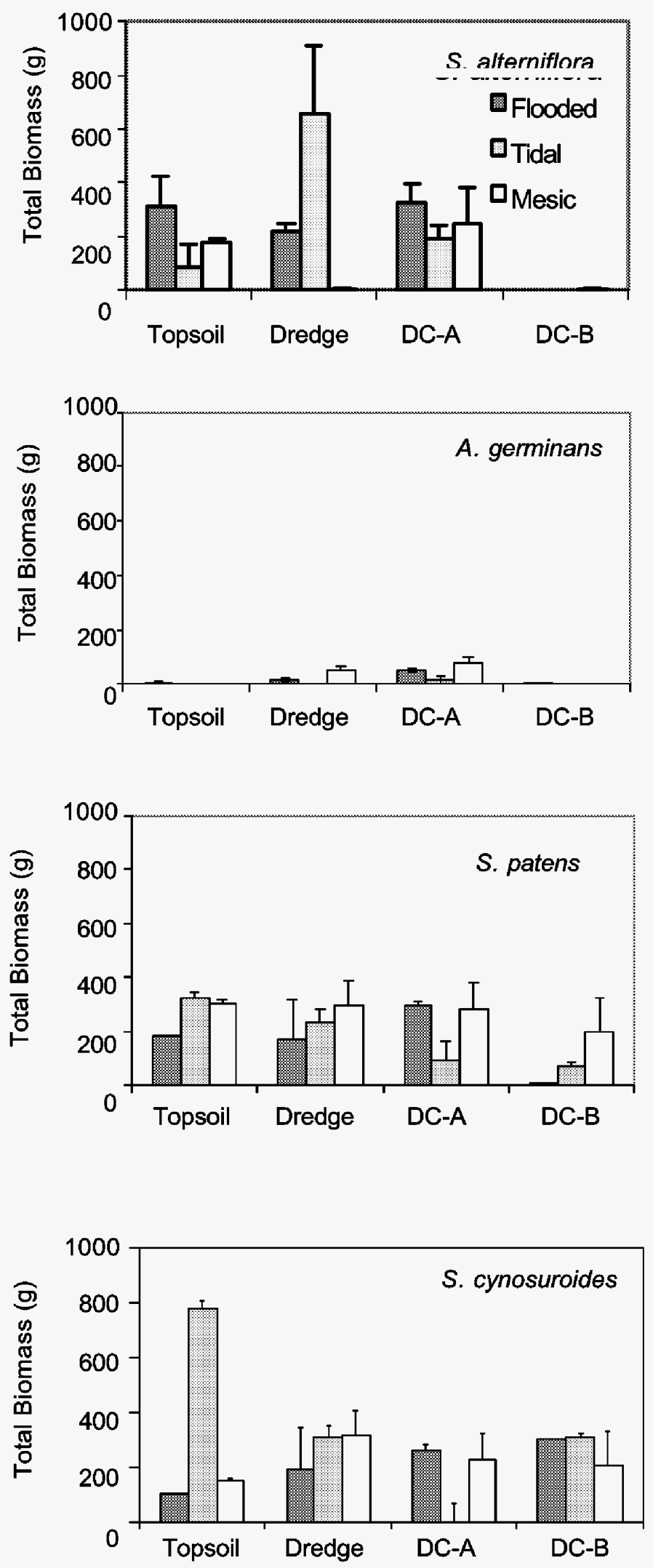

Fig. 17. The effect of substrate type, hydrologic regime, and plant species on total biomass (mean $+/$ - standard error). 


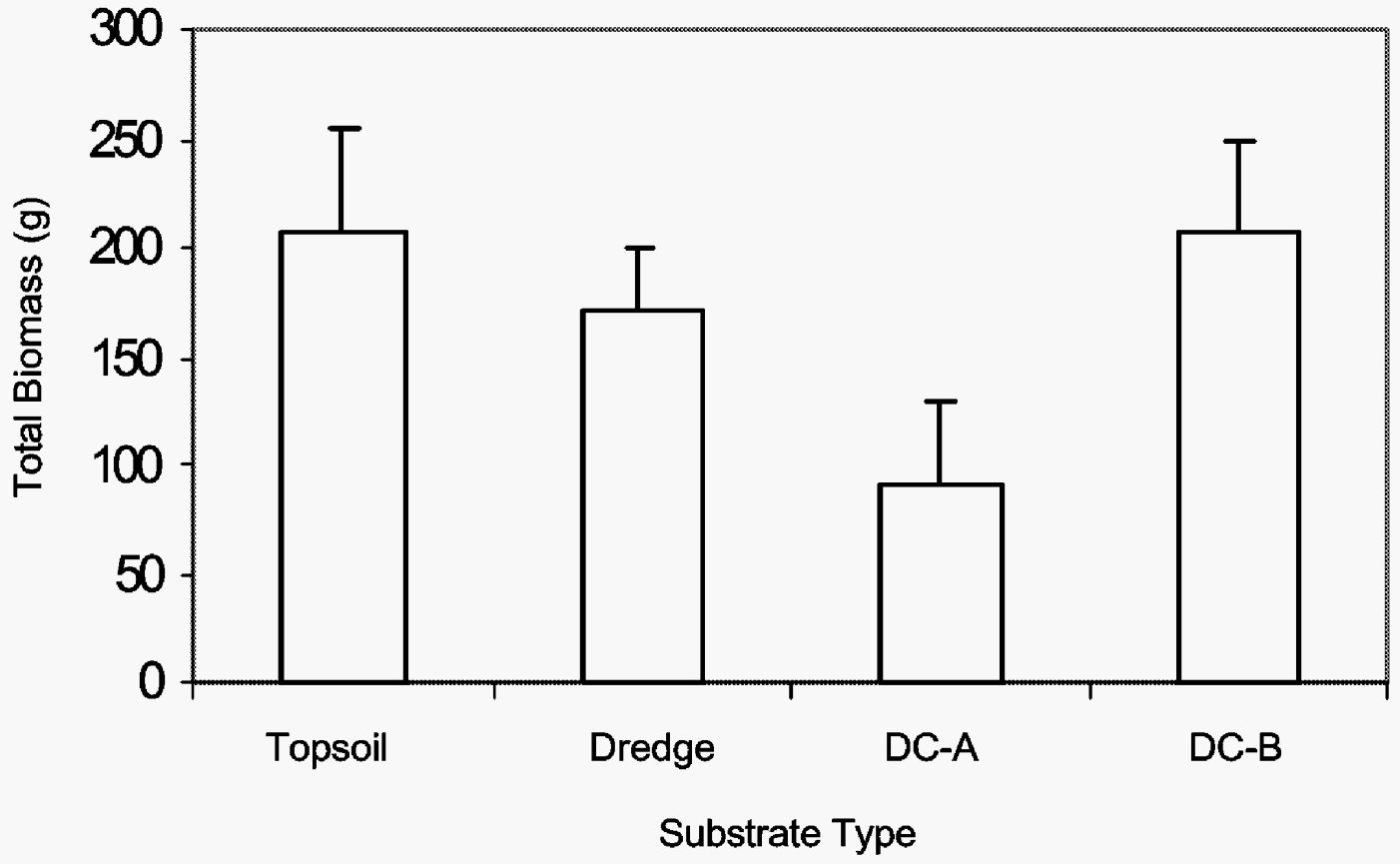

Fig. 18. The effect of substrate type on total biomass (mean $+/-$ standard error) averaged across hydrologic regime and plant species. 


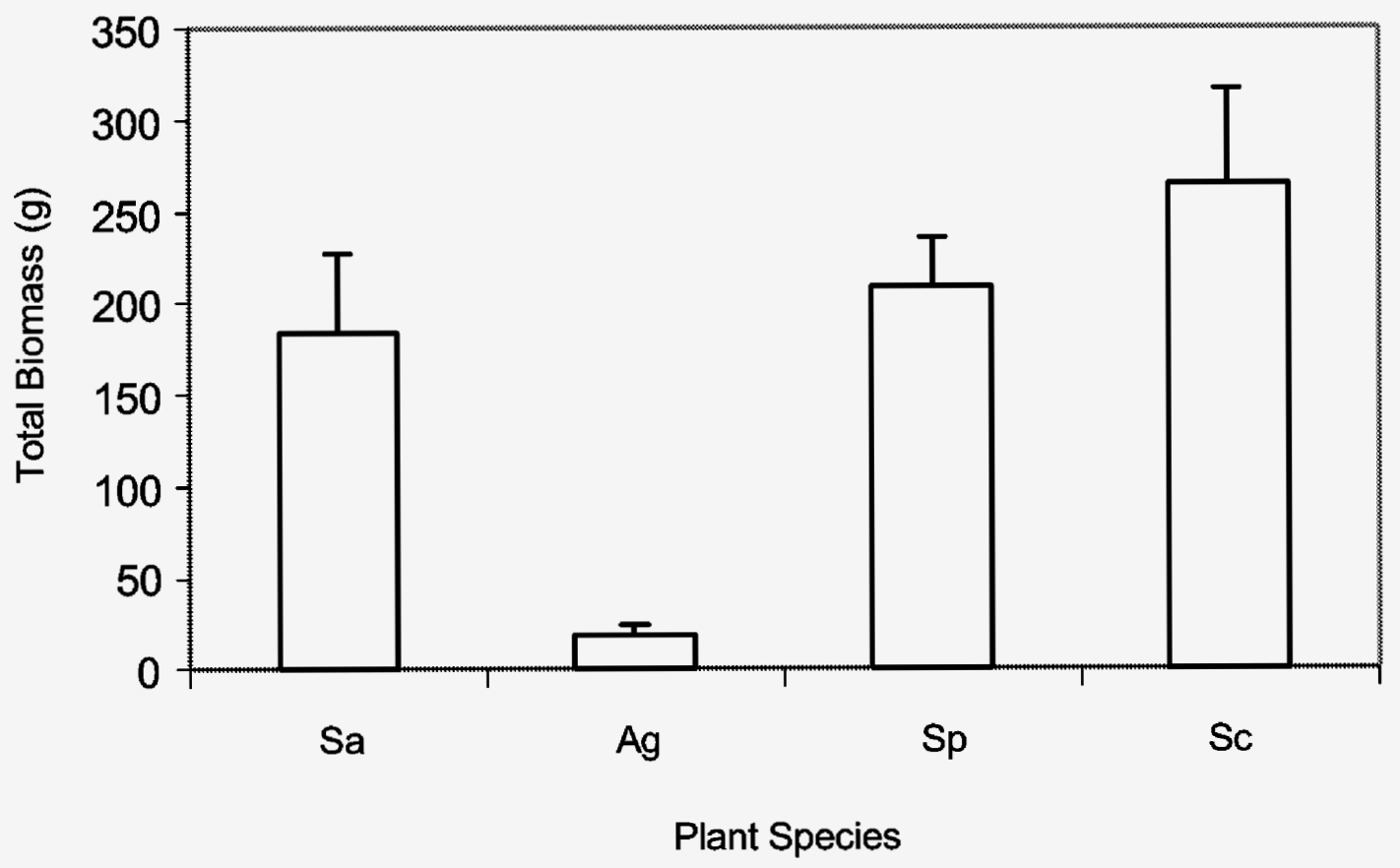

Fig. 19. The effect of plant species on total biomass (mean $+/$ - standard error) averaged across substrate type and hydrologic regime. Species abbreviations are as follows: $\mathrm{Sa}=S$. alterniflora, $\mathrm{Ag}=$ A. germinans, $\mathrm{Sp}=S$. patens, $\mathrm{Sc}=S$. cynosuroides . 


\begin{abstract}
Aboveground Biomass
A significant three-way interaction was noted between substrate, hydrology, and species on aboveground biomass (Fig. 20; $F=2.901, P=0.002$ ). This may have been due to the reduced biomass of $S$. patens in DC-B under flooded conditions, the reduced biomass of S. alterniflora in all DC-B treatments, and also the poor performance of $S$. alterniflora when grown in the dredge spoil substrate under mesic conditions. Plants in DC-B had significantly reduced aboveground biomass compared to plants in other substrates (Fig. 21 ; Contrast $F=54.945, P<0.001$ ). A significant species effect was also detected $(\mathrm{F}=41.549, \mathrm{P}<0.001)$. As stated above, this is likely due to the performance of $A$. germinans (woody species) compared to the herbaceous species and the fact that $S$. cynosuroides had significantly lower aboveground biomass than other Spartina species (Fig. 22; Contrast $\mathrm{F}=6.816, \mathrm{P}<0.012$ ).
\end{abstract}

\title{
Belowground Biomass
}

A significant difference in belowground biomass was detected among species $(F=4.995$, $\mathrm{P}=0.005$ ). Again, this is believed to be due to the reduced biomass of $A$. germinans compared to the other species (Fig. 23; Contrast $F=8.887, P=0.005$ ). No other main effects or interactions were found to be significant.

\section{Stem Heights and Diameters}

Substrate type was found to significantly affect both $A$. germinans stem diameter and height (Fig. 24; $\mathrm{F}=9.573, \mathrm{P}<0.002$ : Fig. 25; $\mathrm{F}=5.172, \mathrm{P}<0.012$ respectively). Bonferroni adjusted pair-wise comparisons indicated that DC-A and dredge spoil resulted in greater stem height and diameter than DC-B and topsoil. No significant effect of hydrologic regime was detected. 

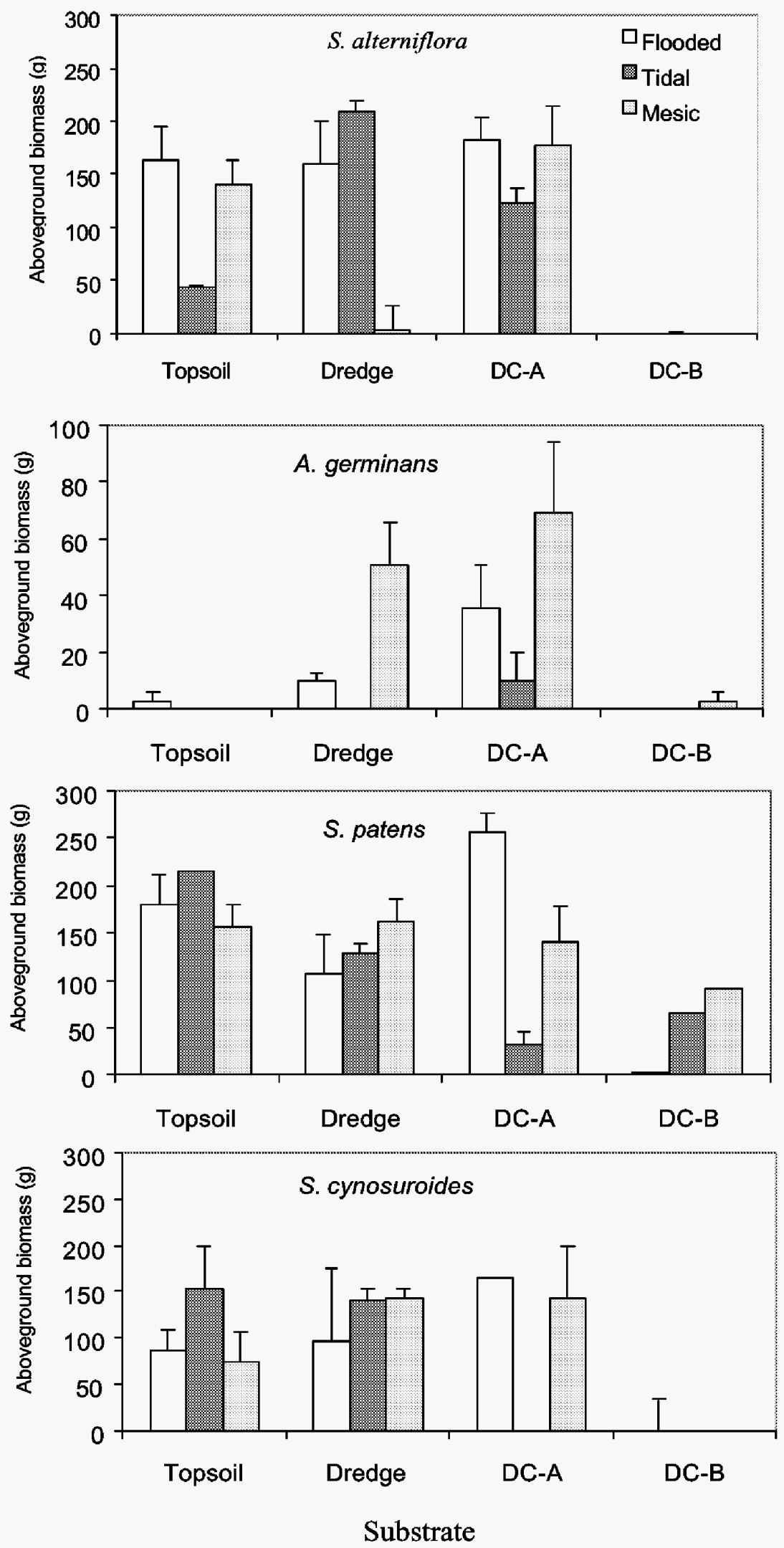

Fig. 20. The effect of substrate type, hydrologic regime, and plant species on aboveground biomass (mean $+/$ - standard error). 


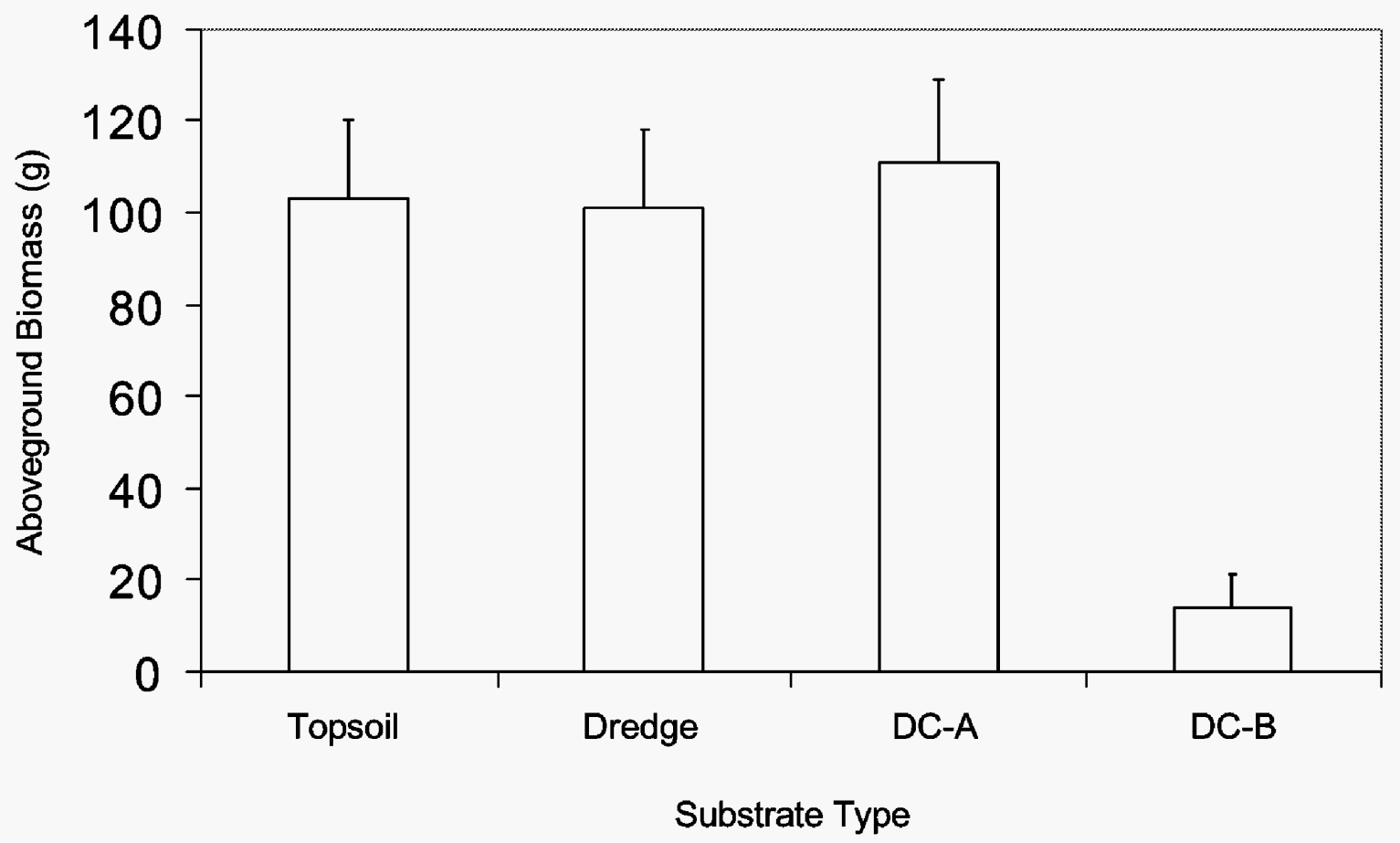

Fig. 21. The effect of substrate type on aboveground biomass (mean $+/$ - standard error) averaged across hydrologic regime and plant species. 


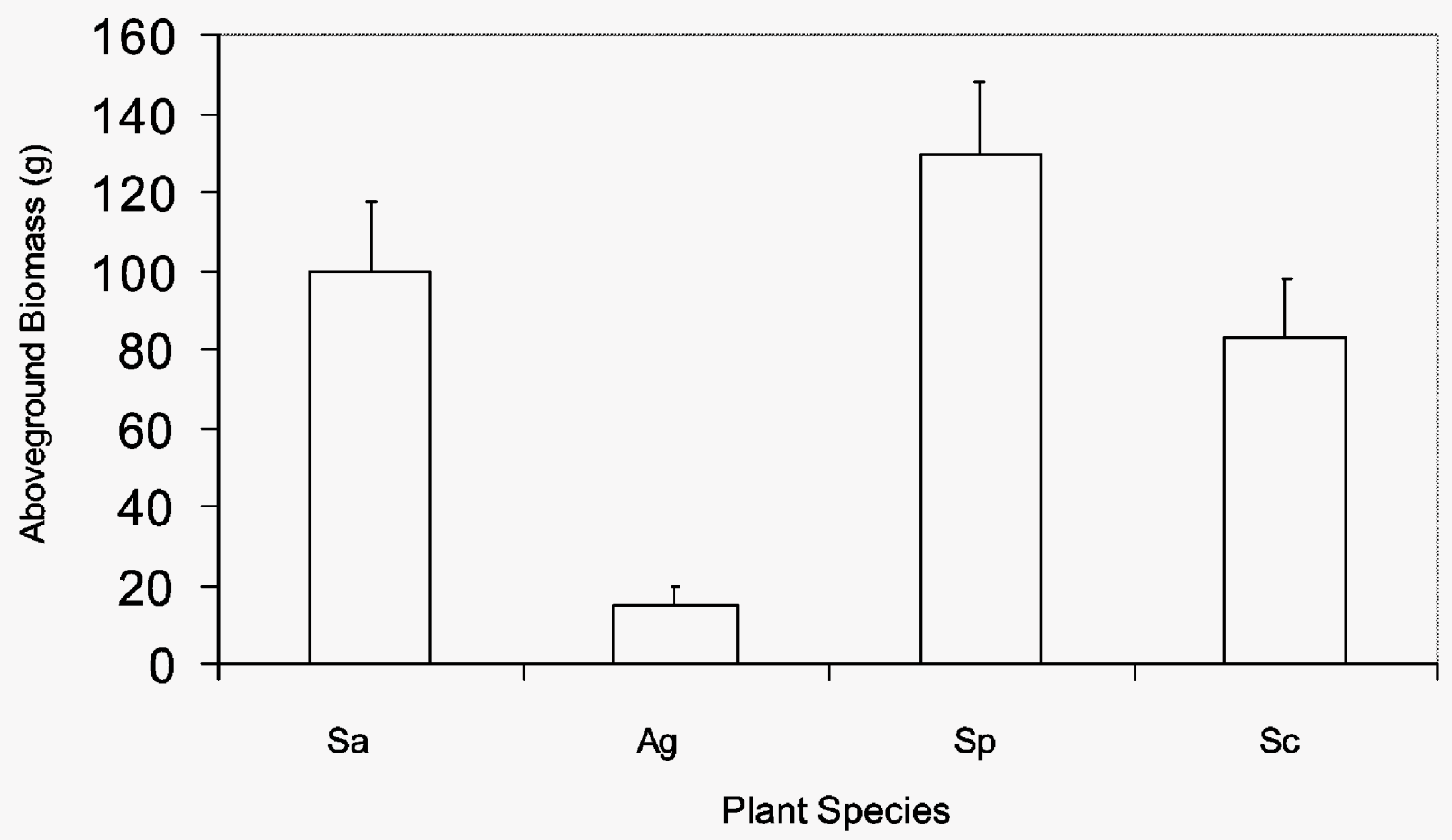

Fig. 22. The effect of plant species on aboveground biomass (mean $+/-$ standard error) averaged across substrate type and hydrologic regime. Species abbreviations are as follows: $\mathrm{Sa}=S$. alterniflora, $\mathrm{Ag}=A$. germinans, $\mathrm{Sp}=S$. patens, $\mathrm{Sc}=S$. cynosuroides. 


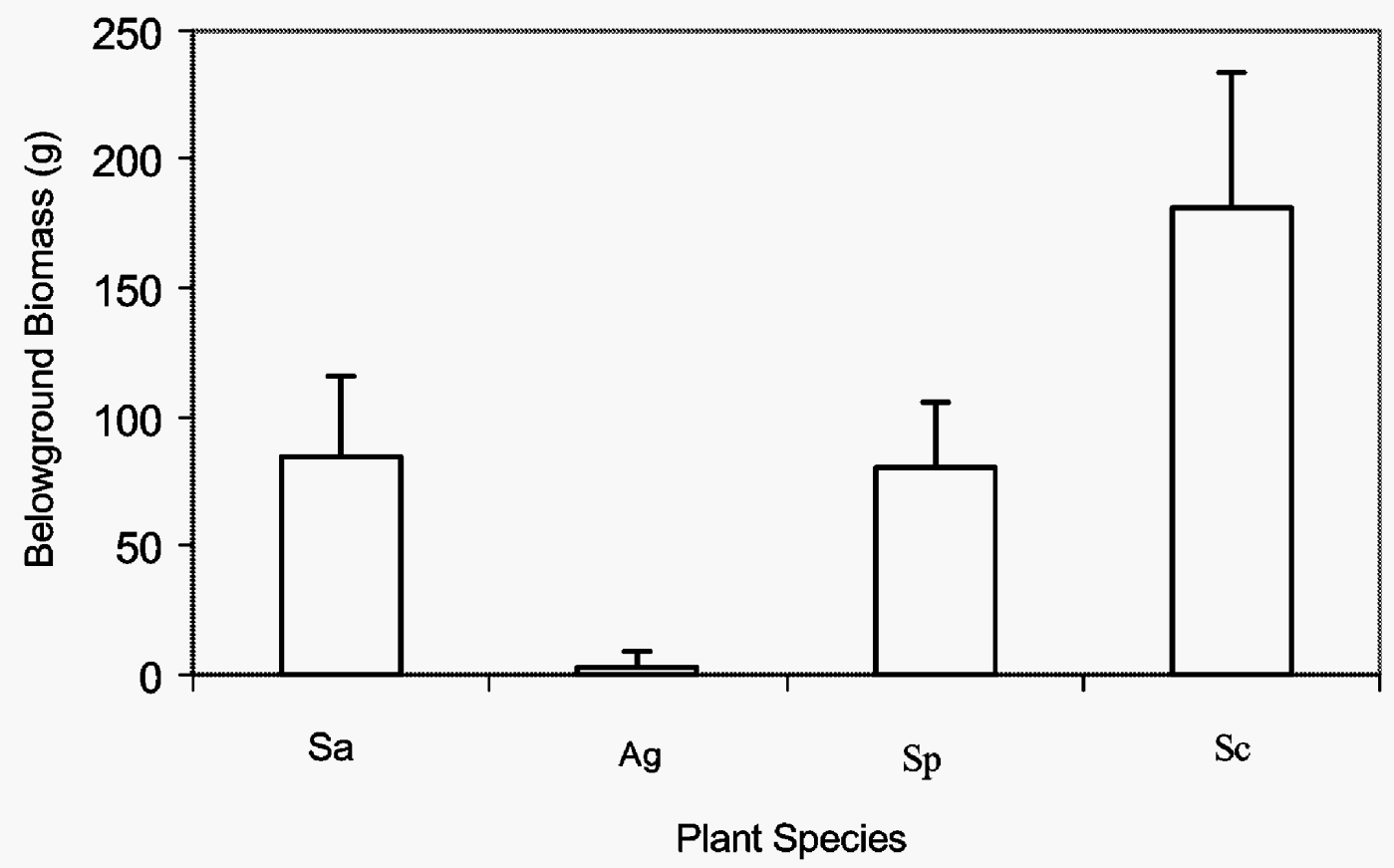

Fig. 23. The effect of plant species on belowground biomass (mean $+/$ - standard error) averaged across substrate type and hydrologic regime. Species abbreviations are as follows: $\mathrm{Sa}=S$. alterniflora, $\mathrm{Ag}=A$. germinans, $\mathrm{Sp}=S$. patens, $\mathrm{Sc}=S$. cynosuroides. 


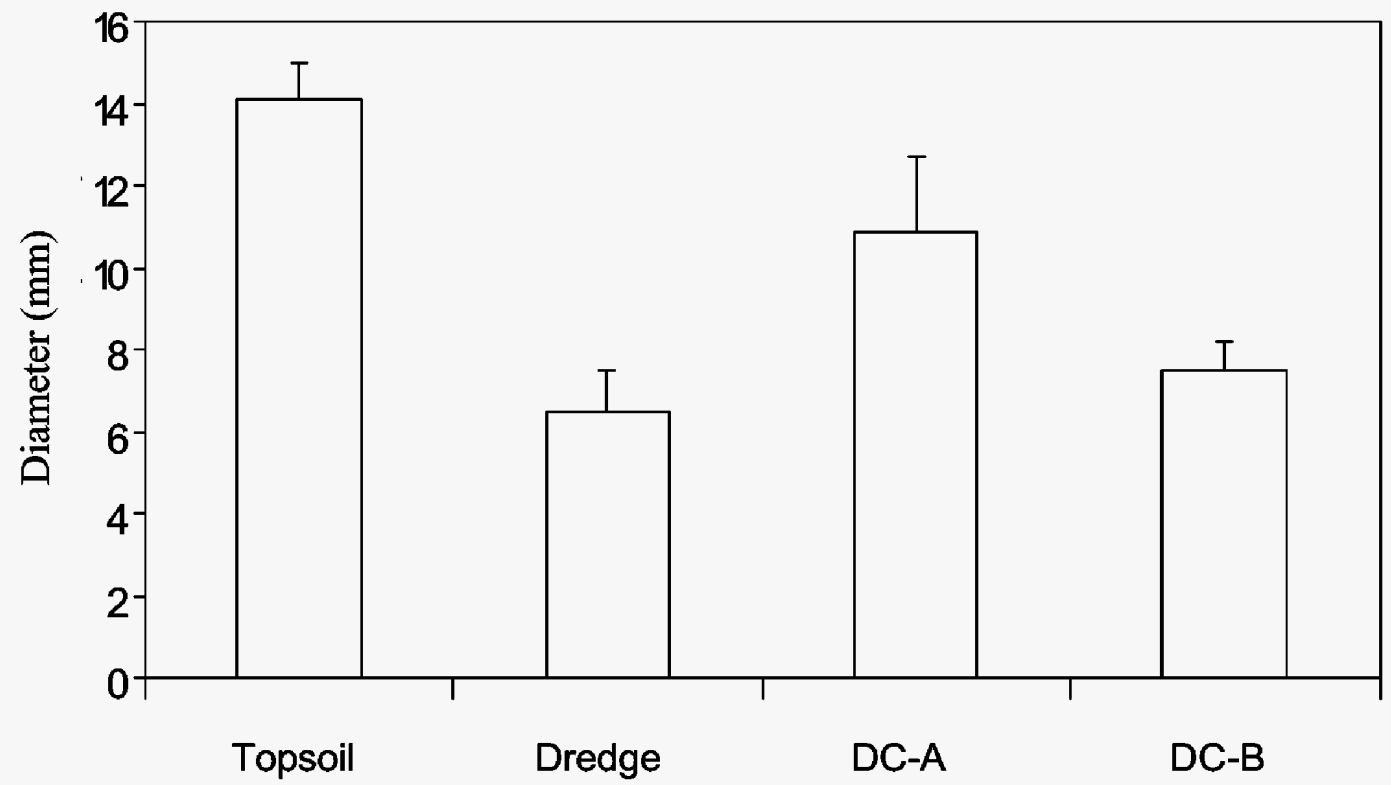

Substrate Type

Fig. 24. The effect of substrate type on Avicennia germinans final diameter (mean +/- standard error) averaged across hydrologic regime. 


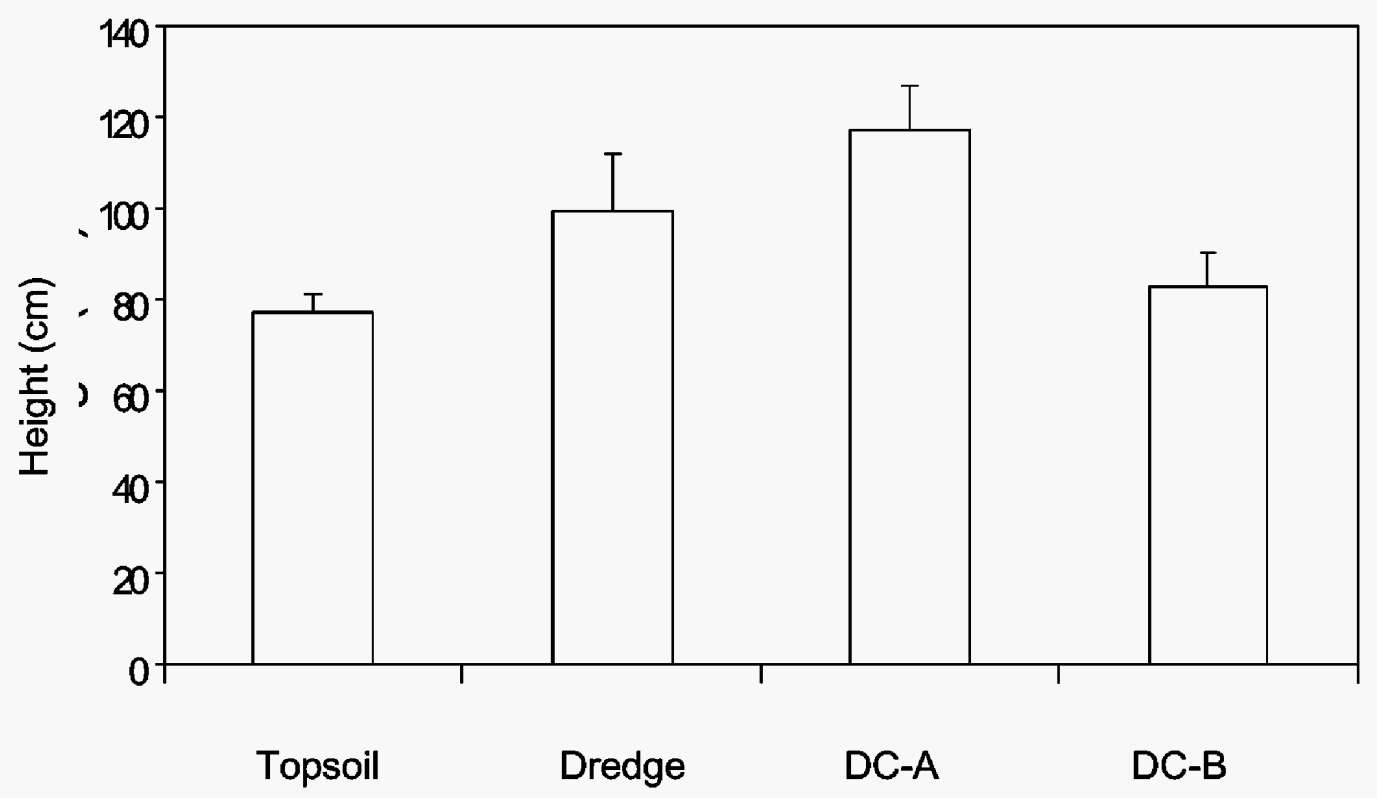

Substrate Type

Fig. 25. The effect of substrate on Avicennia germinans final height (mean $+/$ - standard error) averaged across hydrologic regime. 


\section{Genotypic Response}

Spartina patens genotypes in the 9-ppt treatments had higher net $\mathrm{CO}_{2}$ assimilation rates

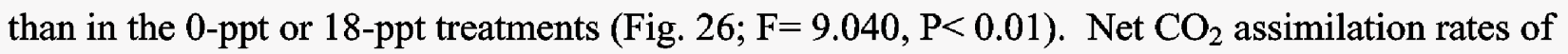
S. patens under the 0-ppt salinity level were reduced in the DC-B substrate, however under all saline treatments $S$. patens net $\mathrm{CO}_{2}$ assimilation rates were comparable across substrates ( Fig. $27 ; \mathrm{F}=2.937, \mathrm{P}<0.028$ ). No other significant differences in photosynthetic response were discerned among $S$. patens genotypes.

A significant interactive effect of substrate, genotype, and hydrology on S. patens aboveground biomass was detected (Fig. 28; $\mathrm{F}=2.181, \mathrm{P}=0.029$ ). This is best explained by the low biomass of genotype 26, compared with genotypes 8 and 9 under flooded conditions in DCB. Although the presence of this three-way interaction somewhat limits the interpretation of the main effect, it should be noted that biomass production by genotype 9 appears to be significantly reduced from genotypes 8 and 26 (Fig. 29; Contrast $\mathrm{F}=7.309, \mathrm{P}=0.01$ ).

Genotype 26 had significantly greater production of belowground biomass than genotypes 8 and 9 (Fig. 30; Contrast $\mathrm{F}=10.508, \mathrm{P}=0.002$ ). Overall $S$. patens produced less belowground biomass under flooded conditions than under mesic or tidal conditions (Fig. 31; Contrast $\mathrm{F}=11.066, \mathrm{P}=0.001$ ). As was observed with photosynthesis $S$. patens belowground biomass was lowest in the DC-B substrate (Fig. 32; Contrast $F=6.942, P=0.011$ ). No significant interactions on belowground biomass were discerned.

Genotype 26 had significantly greater total biomass production than genotype 8 , which in turn had significantly higher biomass production than genotype 9 (Fig. 33; Contrast $\mathrm{F}=5.568, \mathrm{P}=$ 0.006). Mesic conditions resulted in significantly higher total biomass than observed under flooded conditions (Fig. 34; 11.123, $\mathrm{P}=0.001$ ). As in the belowground biomass analysis, $S$. 


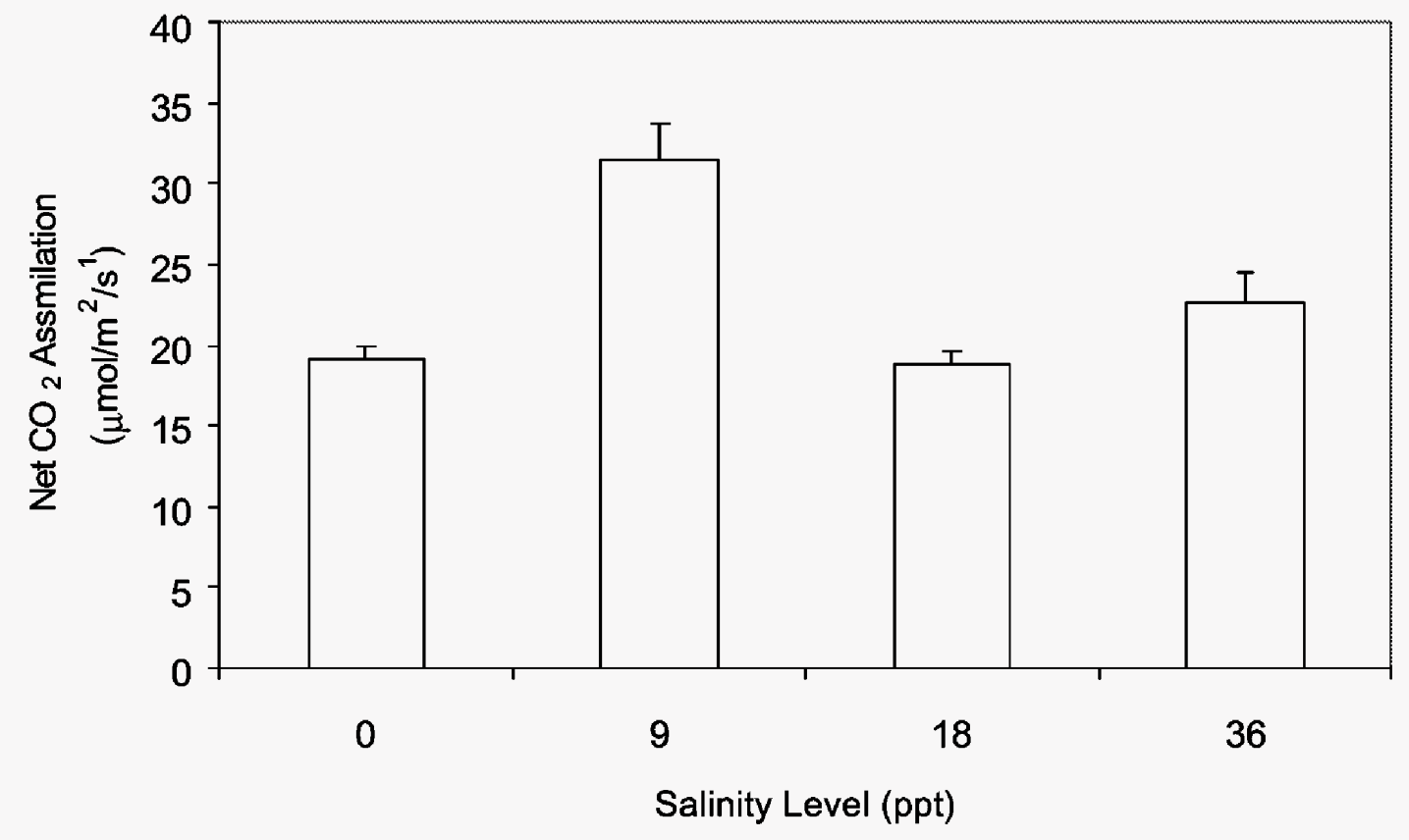

Fig. 26. The effect of salinity on Spartina patens net $\mathrm{CO}_{2}$ assimilation rates (mean $+/$ - standard error) averaged across substrate type, hydrologic regime, Spartina patens genotype. 


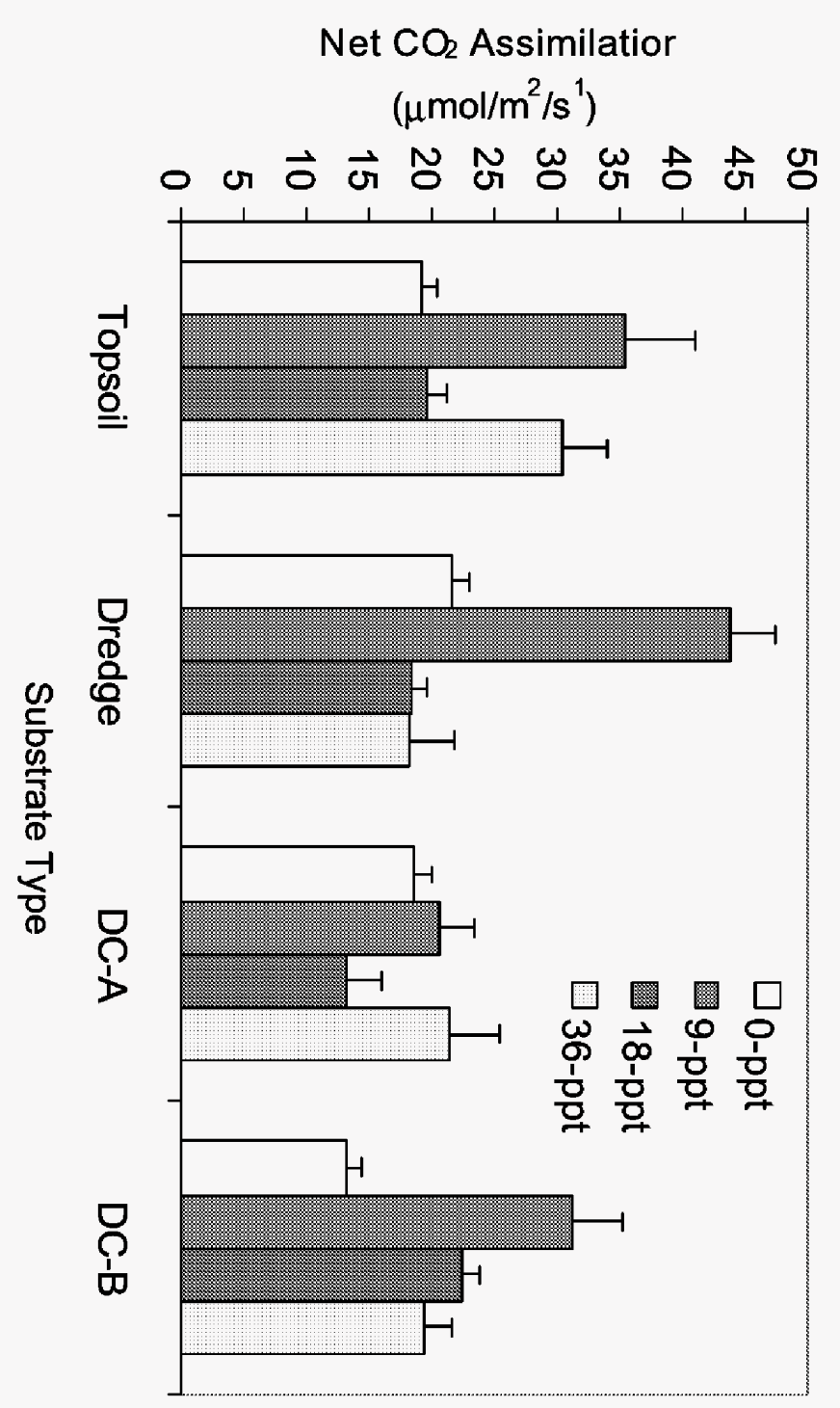



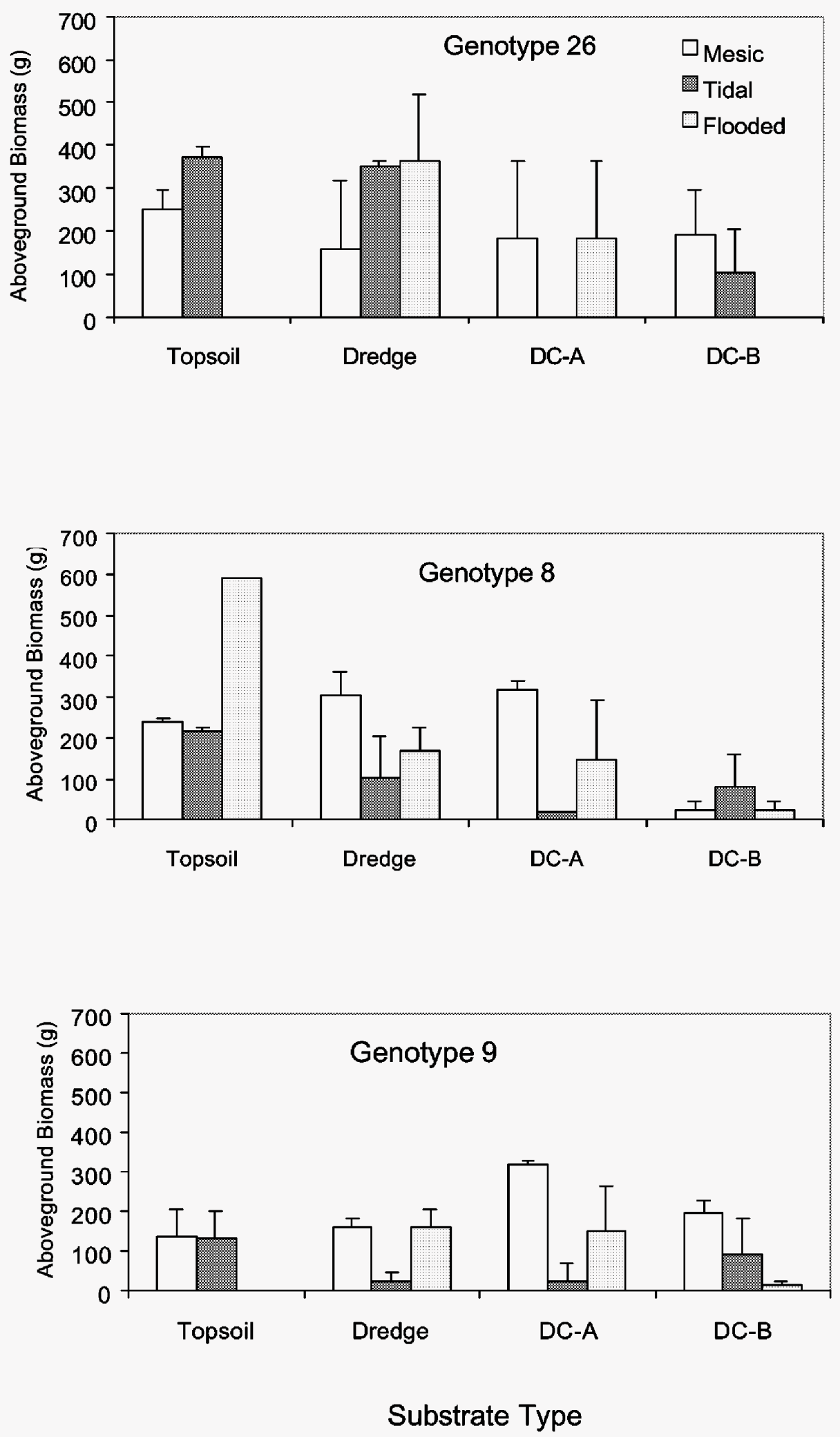

Fig. 28. The effect of substrate type, hydrologic regime, and Spartina patens genotype on Spartina patens aboveground biomass (mean $+/$ - standard error). 


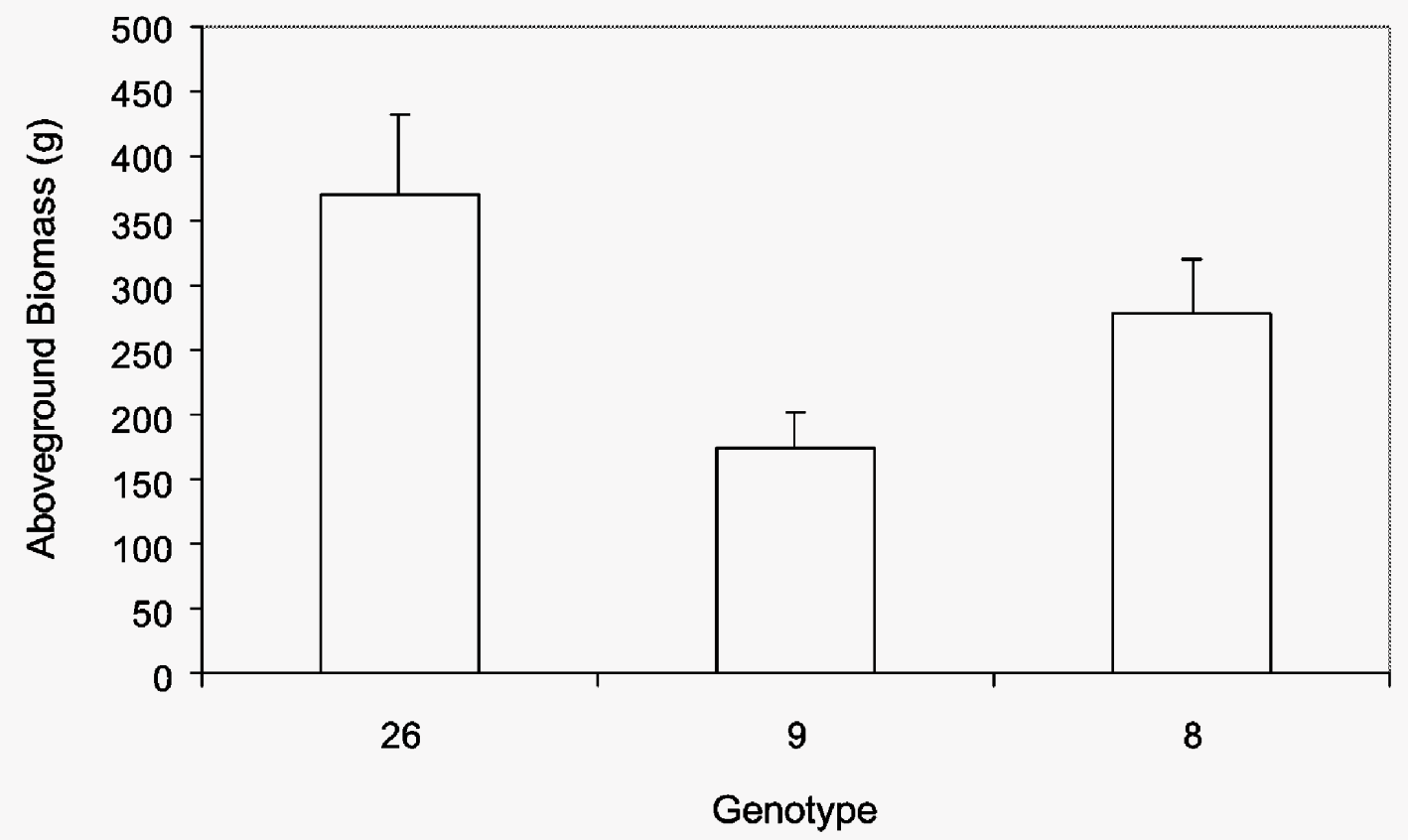

Fig. 29. The effect of Spartina patens genotype on Spartina patens aboveground biomass (mean $+/$ - standard error) averaged across substrate type and hydrologic regime. 


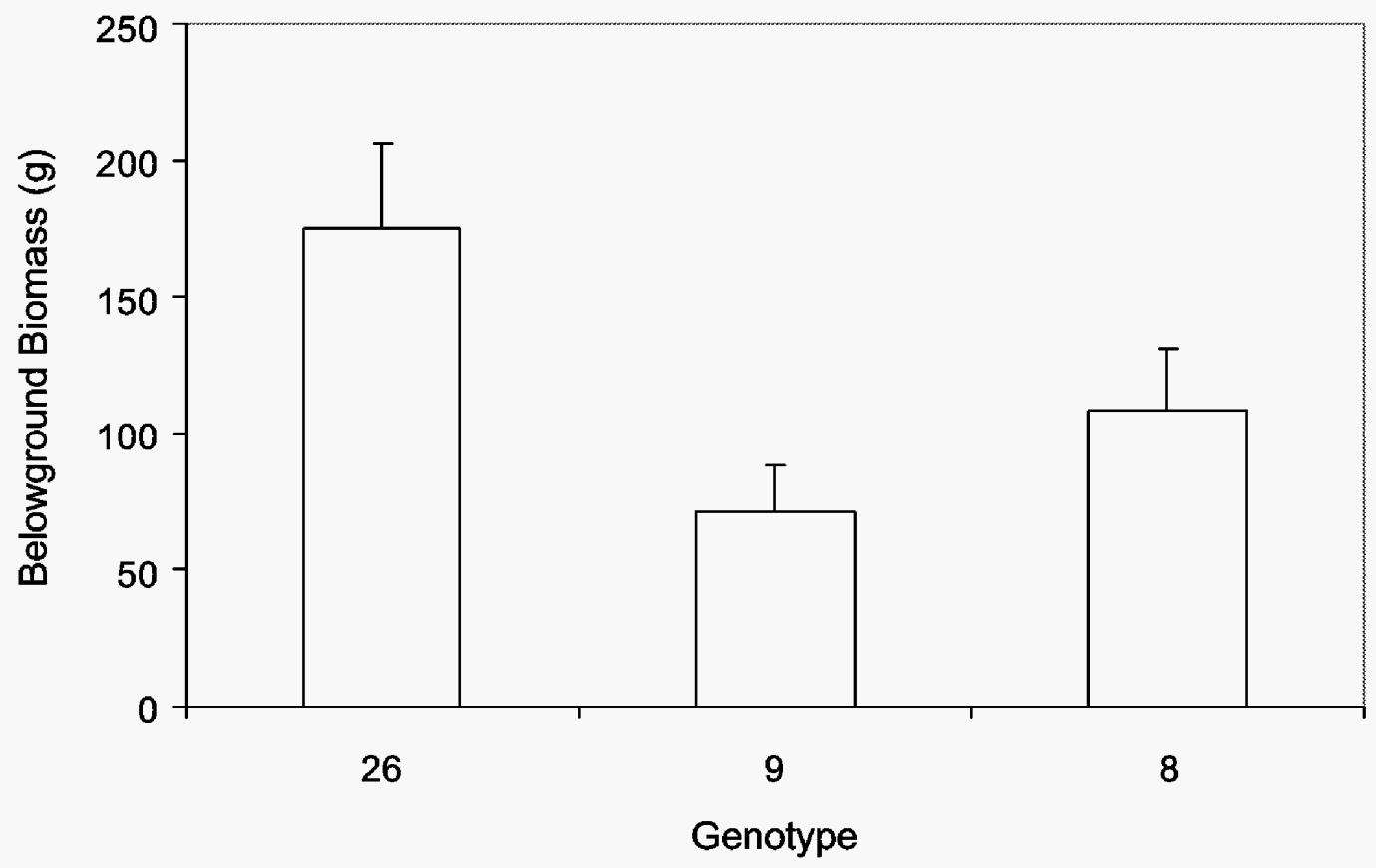

Fig. 30. The effect of Spartina patens genotype on Spartina patens belowground biomass (mean $+/$ - standard error) averaged across substrate type and hydrologic regime. 


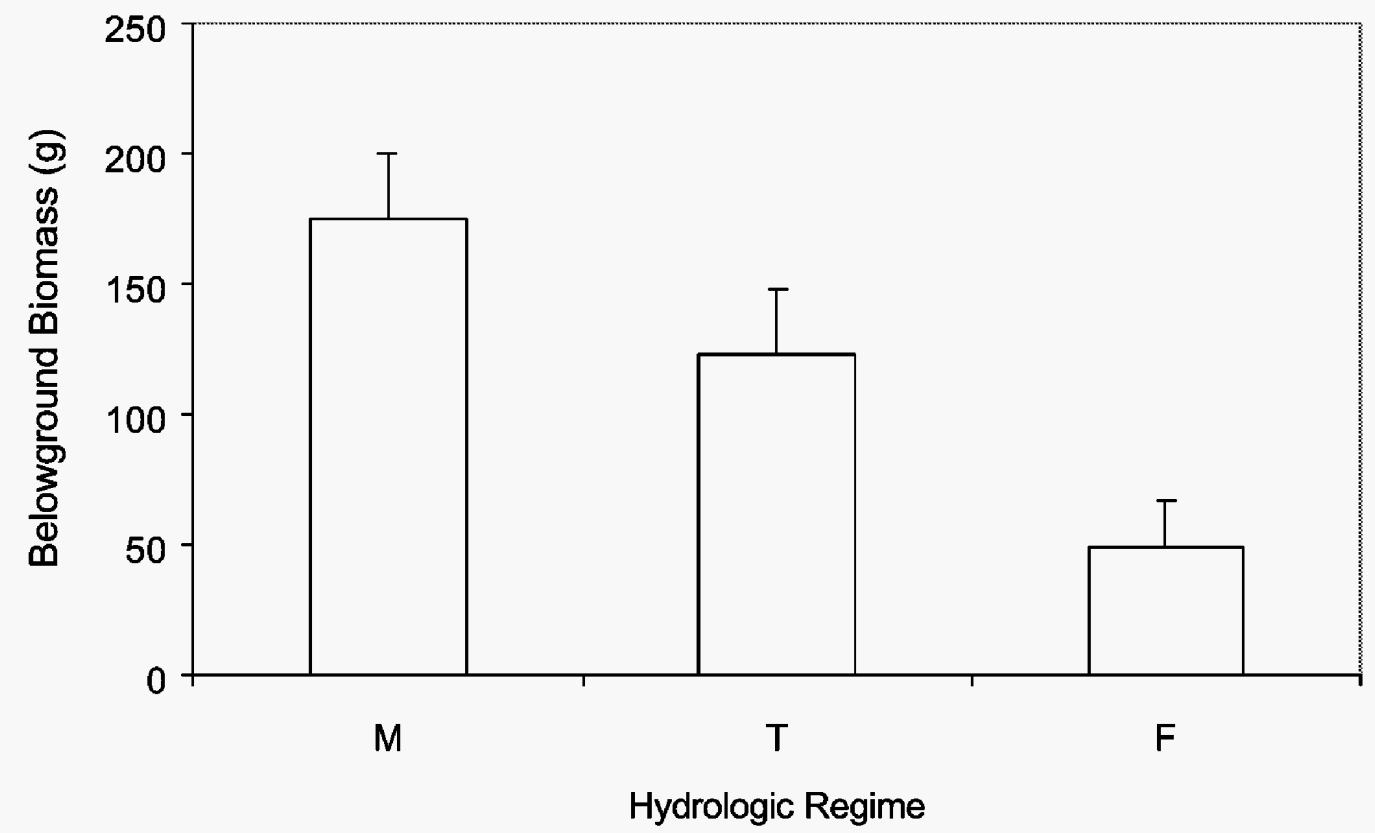

Fig. 31. The effect of hydrologic regime on Spartina patens belowground biomass (mean $+/$ - standard error) averaged across substrate type and Spartina patens genotype. 


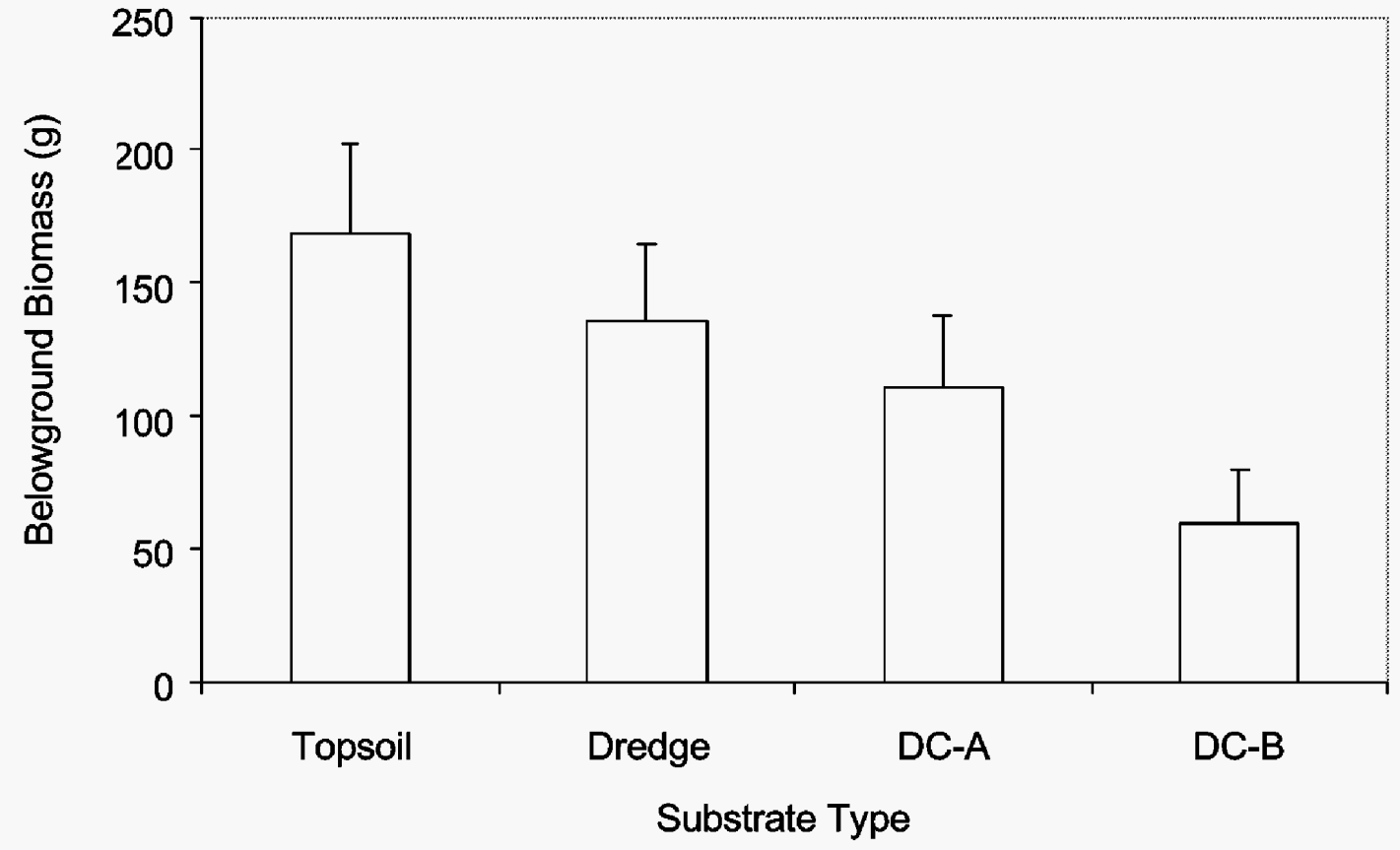

Fig. 32. The effect of substrate type on Spartina patens belowground biomass (mean $+/$ standard error) averaged across hydrologic regime and Spartina patens genotype. 


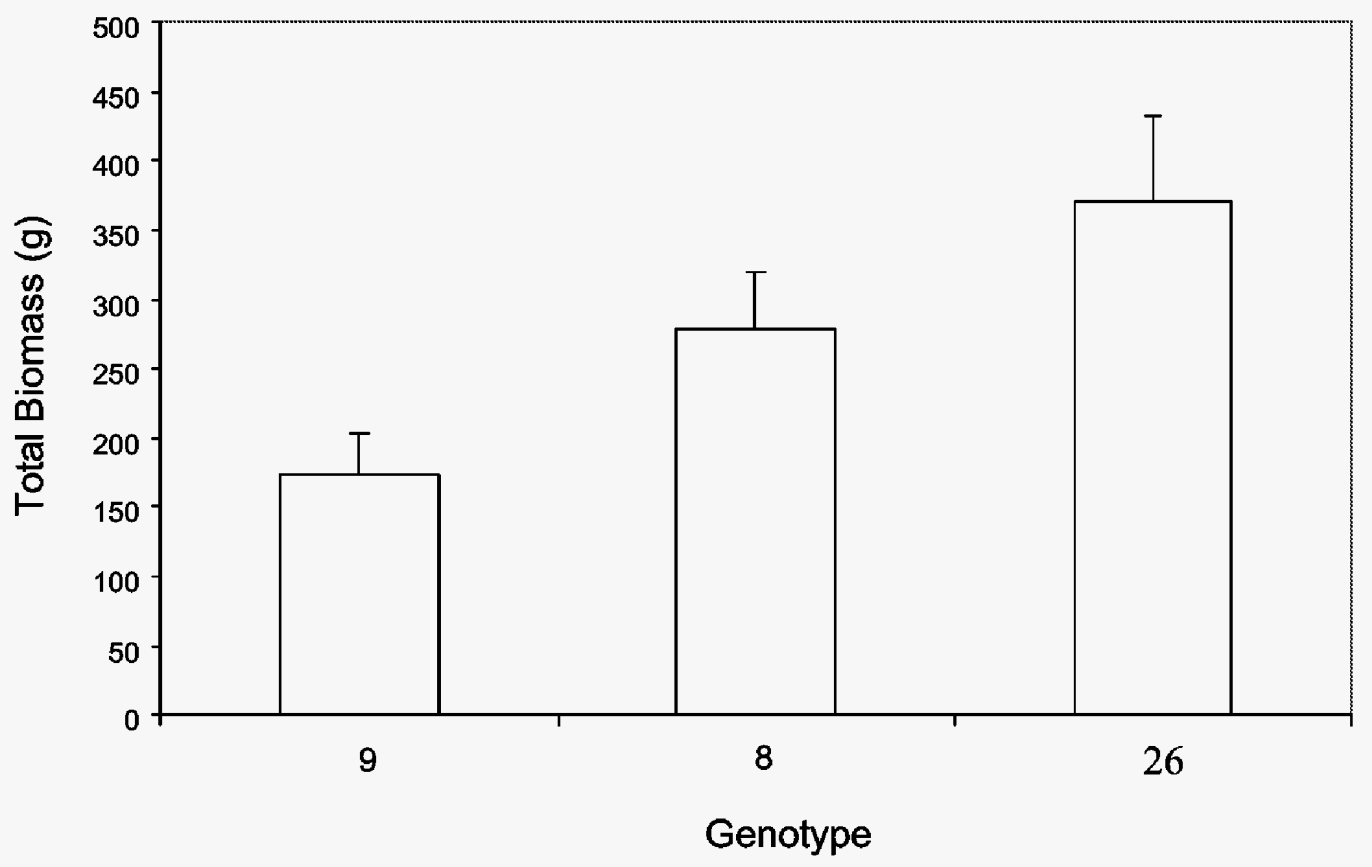

Fig. 33. The effect of Spartina patens genotype on total Spartina patens biomass (mean $+/$ - standard error) averaged across substrate type and hydrologic regime. 


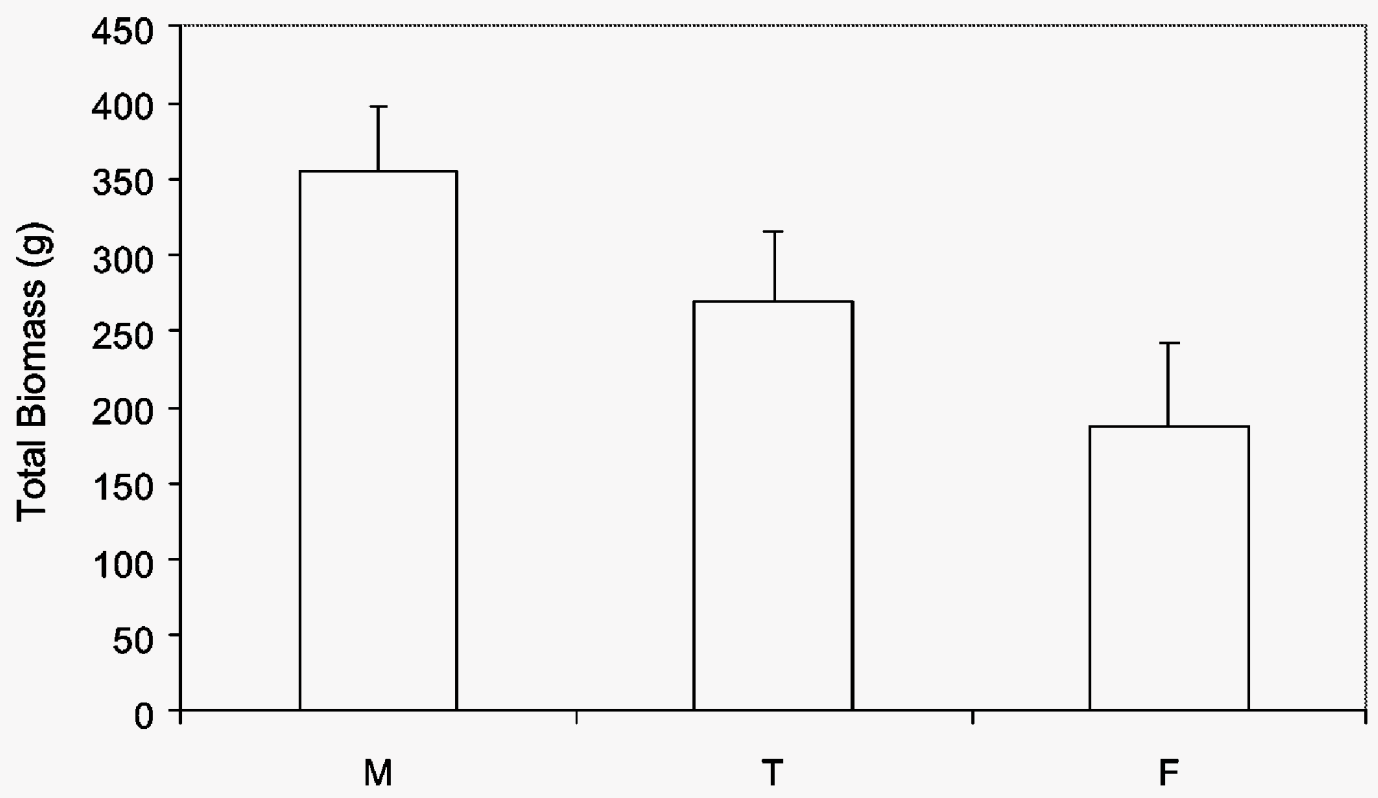

Hydrologic Regime

Fig. 34. The effect of hydrologic regime on Spartina patens total biomass (mean $+/$ - standard error) averaged across substrate type and Spartina patens genotype. 
patens total biomass was lowest in the DC-B substrate compared to all other substrates (Fig. 35;

Contrast $\mathrm{F}=10.185, \mathrm{P}=0.002$ ). No significant interactions on total biomass were detected.

Similar to the responses observed in $S$. patens, the 9-ppt salinity level resulted in significantly higher net $\mathrm{CO}_{2}$ assimilation rates in $S$. alterniflora than in the other salinity levels (Fig. 36; $\mathrm{F}=4.828, \mathrm{P}=0.025$ ). All genotypes of $S$. alterniflora showed depressed net $\mathrm{CO}_{2}$ assimilation under fresh water conditions in the DC-B substrate, but exhibited net $\mathrm{CO}_{2}$ assimilation rates comparable with, or superior to, other substrates under the 9-ppt and 36-ppt salinity level (Fig. 37; F=2.826, $\mathrm{P}=0.025$ ). 


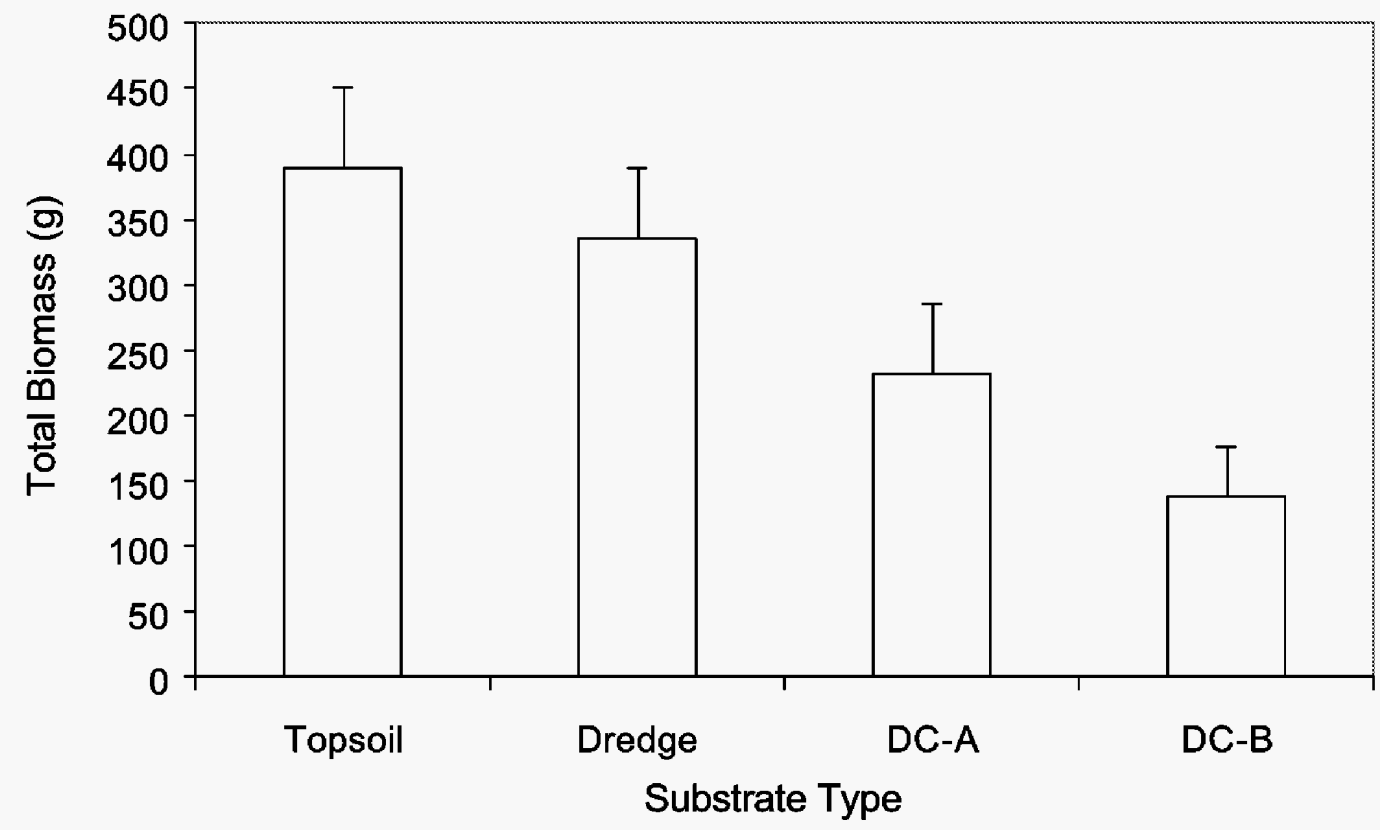

Fig. 35. The effect of substrate type on total Spartina patens total biomass (mean $+/$ - standard error) averaged across hydrologic regime and Spartina patens genotype. 


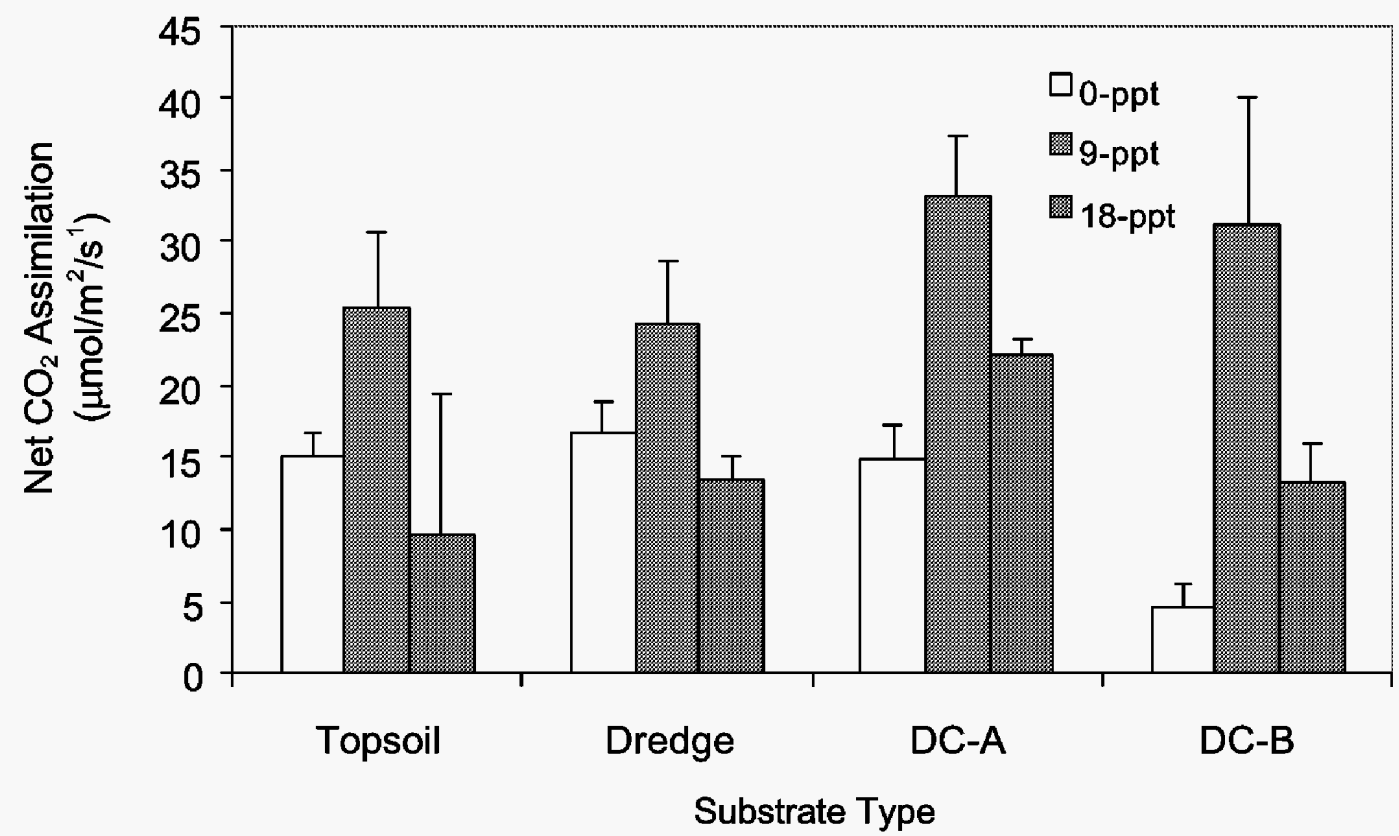

Fig. 36. The effect of salinity level and substrate type on Spartina alterniflora net $\mathrm{CO}_{2}$ assimilation rates (mean $+/$ - standard error) averaged across hydrologic regime and Spartina alterniflora genotype. 

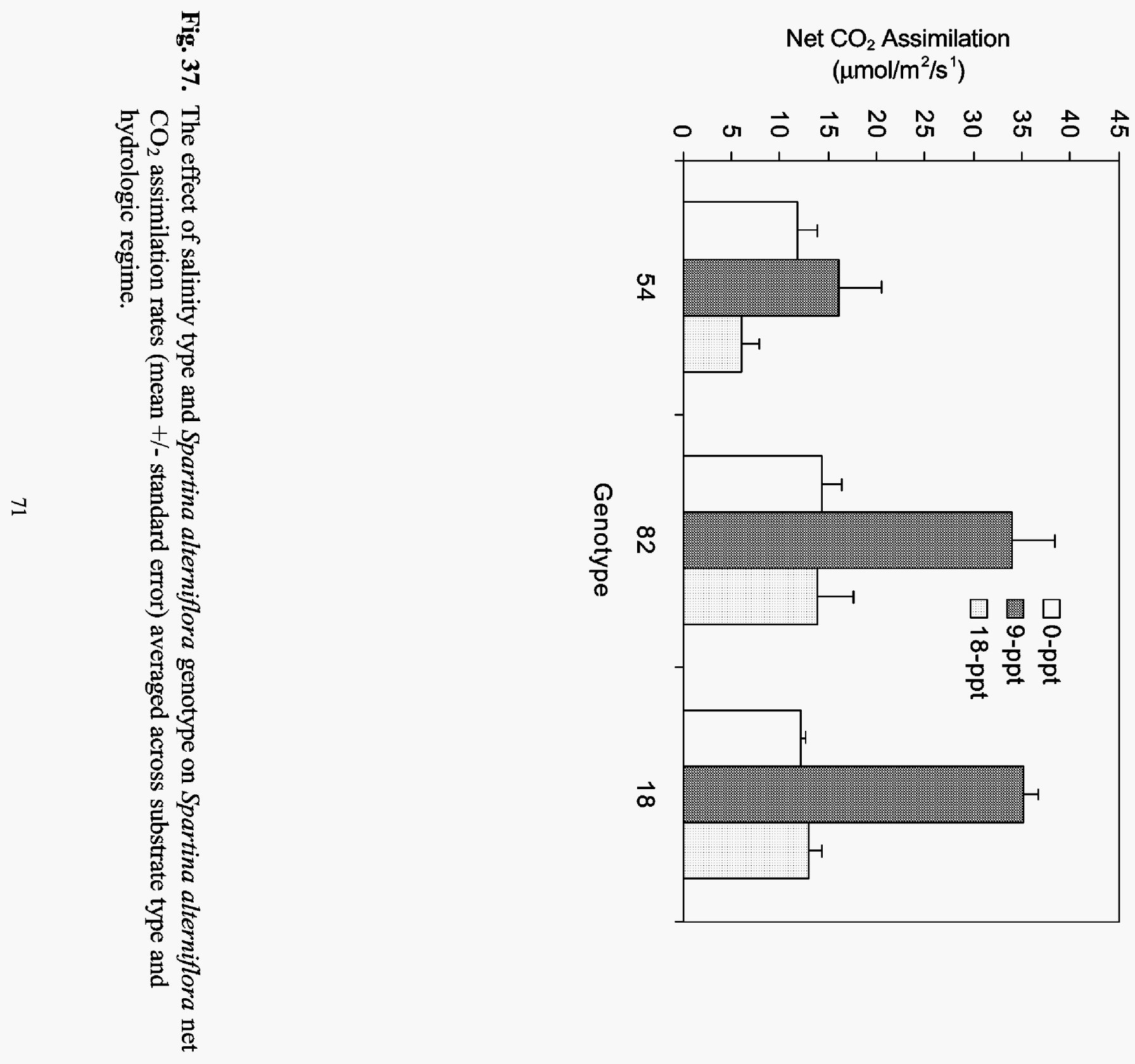

Discussion

73 

The previous mesocosm (freshwater) studies that were conducted under non-saline conditions indicated that the DC-A substrate had greater potential as an alternative wetland substrate than DC-B, which supported much more limited plant growth. The low growth of plants in the DC-B substrate compared to the other substrates was attributed to the high $\mathrm{pH}$ and very coarse texture of the substrate. This study has further elucidated the potential of both DC-A and DC-B as alternative wetland substrates in terms of edaphic variables and vegetation response under scenarios of increasing salinity.

\section{Edaphic Variables}

As one would expect, soil redox potentials became significantly more reduced as salinity levels were increased (DeLaune et al. 1976). Because salinity levels were increased over time, this reduction in soil redox potential likely reflects both an increase in the duration of flooding and the presence of sulfate in the sea-salt mix. Sulfate is reduced to sulfide by microbiological activity at a redox potential of approximately $-100 \mathrm{mV}$ (Mitsch and Gosselink 1993). Although soil redox potentials as low as $-500 \mathrm{mV}$ were reported, the mean values were above $-100 \mathrm{mV}$ at each salinity level. This indicates that oxidized Fe and $\mathrm{Mn}$ were probably present, at least part of the time, in the interstitial water. Both of these metals can serve as electron acceptors for metabolic activity that are energetically more efficient than sulfate, and the usage of these alternative acceptors is reflected in higher redox potentials (100-150 mV) (Mitsch and Gosselink 1993).

Substrate interstitial $\mathrm{pH}$ in the DC-B substrate was dramatically lowered from extreme alkaline values $(\sim 10.1)$ to moderate $\mathrm{pH}$ values $(\sim 8.5)$ by the addition of seasalt. Seawater has a strong buffering capacity because of the carbon dioxide-calcium carbonate equilibrium system, which allows it to buffer both basic and acidic systems (Dietrich et al. 1980). Therefore, it would seem likely that some interaction of this carbon dioxide-calcium carbonate system with aluminum hydroxide (thought to be a major constituent of DC-B) was involved in the lowering of alkalinity in DC-B as salinity levels increased above 0 ppt. This is of great significance because the high alkalinity was considered to be a major obstacle to the successful establishment 
of vegetation in the DC-B substrate. This $\mathrm{pH}$-salinity phenomenon was not noted in the Kelly and Mendelssohn (1995) study. This is likely due to the difference in size of the experiments, specifically the size of the water reservoirs. Because of the large volume of the mesocosm water reserves in this study, a larger buffering capacity was likely available to ameliorate the high $\mathrm{pH}$ of the DC-B substrate. It is documented that the interstitial $\mathrm{pH}$ of submerged soils will tend to approach neutrality over time (Ponnamperuma 1972). However, it is unlikely that this is the main factor behind the amelioration of the $\mathrm{DC}-\mathrm{B}$ substrate $\mathrm{pH}$ because no reduction in $\mathrm{pH}$ was detected after the submergence of the DC-B substrate in the previous studies. Therefore, the reduction of the DC-B substrate $\mathrm{pH}$ is likely a direct result of the increase in salinity level, especially since this $\mathrm{pH}$ reduction corresponds exactly with increase in the salinity level.

Previous drill cuttings research indicated that the use of processed drill cuttings to create wetlands may require anthropogenic amelioration of the high $\mathrm{pH}$ in order to be successful, which would reduce cost-effectiveness of the method (Kelley and Mendelssohn 1995; Shaffer et al. 1996; DesRoches 1997). However, an implication of this study is that if these processed drill cuttings are used for coastal wetland restoration where natural saline waters are present, then there may be no need to amend the alkalinity of the substrate with organic materials as was previously thought necessary (Kelley and Mendelsson 1995).

Substrate interstitial $\mathrm{pH}$ and soil redox potential are considered primary variables that control the release and solubility (and hence bioavailability) of heavy metals in substrates (Fergusson 1990). Bourg and Loch (1995) also include organic matter interactions with interstitial $\mathrm{pH}$ and soil redox potential as master variables that control metal release from sediments. For the majority of heavy metals in aquatic systems, maximum potential release occurs at moderately low and extremely high $\mathrm{pHs,} \mathrm{and} \mathrm{under} \mathrm{slightly} \mathrm{reduced} \mathrm{or} \mathrm{oxidized}$ conditions (Fergusson 1990; Bourg and Loch 1995). The low solubility of metals under low soil redox (i.e., very reduced conditions) is linked to the amount of sulfate present (Bourg and Loch 1995). If sulfate is not available to precipitate metals under low Eh, then contaminants will increase in solubility (Bourg and Loch 1995). Soil redox potential also plays a major role in the 
availability of metals by controlling interactions with $\mathrm{Mn}, \mathrm{Fe}$, and redox-sensitive, precipitateinducing anions (Bourg and Loch 1995). Gambrell et al. (1991) examined the effect of salinity, $\mathrm{pH}$, and Eh on the solubility of certain metals $(\mathrm{Cd}, \mathrm{Cr}, \mathrm{Cu}, \mathrm{Zn}, \mathrm{Ni}$, and $\mathrm{Pb})$ in a contaminated estuarine substrate and found that reduced, basic conditions promoted inavailibility, whereas oxidized, acidic conditions increased solubility. The conditions reported by Gambrell et al. (1991) for minimal solubility $(\mathrm{pH}=8.0$ and soil redox potential of -150 to $-100 \mathrm{mV}$ ) are similar to the environmental conditions in the mesocosm at the 18-ppt and 36-ppt salinity levels.

As previously discussed, this mesocosm design is a closed system. Any metals that might be released from the substrates can not escape from the system or become diluted by outside water sources; therefore, all should be accounted for by the elemental analyses of sites of potential sorption/solution (i.e., substrate matrix, interstitial water, algae, macrophytes, and fauna). Essentially, all values for $\mathrm{pH}$ and $\mathrm{Eh}$ that could be expected in natural systems were reached during the experiment under fresh and saline conditions, with no significant differences from the control (i.e., topsoil) in any of the metals of concern.

One concern from our previous studies was potential aluminum phytotoxicity. Aluminum toxicity can be ameliorated through two major mechanisms: the addition of ligand forming agents and the addition of certain cations (Kinraide and Parker 1987). Amelioration can occur by binding of the $\mathrm{Al}^{+}$cations by chelators such as hydroxides (i.e, $\mathrm{Al}^{+}+3 \mathrm{OH}^{-}=\mathrm{Al}[\mathrm{OH}]_{3}$; Kinraide and Parker 1987). The presence of certain cations, markedly $\mathrm{Ca}$ and $\mathrm{Mg}$, relieve $\mathrm{Al}$ toxicity through competitive binding to extracellular surfaces, thereby limiting $\mathrm{Al}$ uptake (Kinraide and Parker 1987). Whatever mechanism was responsible for the reduction in Al concentration in the interstitial waters of the DC-B substrate, the increased concentrations of Ca and $\mathrm{Mg}$ that naturally occur in seawater should limit the uptake of $\mathrm{Al}$ by vegetation. Indeed, plant tissue concentrations in this study were much less than observed in the previous studies.

Examination of aboveground plant tissue indicated significantly higher levels of $\mathrm{Ba}$ in the DC-A substrate $(22.15 \mu \mathrm{g} / \mathrm{g})$ and DC-B substrate $(20.25 \mu \mathrm{g} / \mathrm{g})$ compared to topsoil $(6.03 \mu \mathrm{g} / \mathrm{g})$ and dredge spoil $(6.73 \mu \mathrm{g} / \mathrm{g})$. However, normal levels of Ba for plant foliar levels are considered 
to be between $10-50 \mu \mathrm{g} / \mathrm{g}$ (Chaudhry et al. 1977; also see references in Cipollini and Pickering 1985). For example, Smith (1971) examined uptake of total barium by Triticum vulgare (wheat) in three agricultural soils in Western Australia and found concentrations ranging from $19.7 \mu \mathrm{g} / \mathrm{g}$ to $76.9 \mu \mathrm{g} / \mathrm{g}$ in stem and leaf material. It should also be noted that studies of Ba toxicity in laboratory mice have indicated no discernable effect when given drinking water containing up to $250 \mu \mathrm{g} / \mathrm{g}$ of $\mathrm{Ba}$ (USEPA 1985). Therefore, the levels of $\mathrm{Ba}$ in plant tissue grown on the two processed drill cutting substrates, although elevated compared to topsoil and dredge spoil, are not exceptionally high. Barite $\left(\mathrm{BaSO}_{4}\right)$ is often employed in drilling fluids and this is presumed to be the major source of $\mathrm{Ba}$ in the processed drill cuttings substrates. Solubility (i.e., potential for accumulation) of $\mathrm{Ba}$ compounds varies from extremely low $\left(\mathrm{BaSO}_{4}\right)$ to extremely high $(\mathrm{BaCb})$ (USEPA 1985). Carbonell et al (1999) determined that barite can be responsible for significant levels of soluble barium under acidic, reduced conditions. Although no $\mathrm{pH}$ levels were ever detected below 7.0 during the experiment, it should be noted that $\mathrm{pH}$ was measured on interstitial water. Because plants generate proton gradients to absorb nutrients in the root zone, it is possible that the $\mathrm{pH}$ immediately surrounding the roots was low enough to increase Ba solubility for enhanced plant uptake (Larcher 1995). Once $\mathrm{Ba}$ is assimilated by the plant, it is likely converted to some nonionic, low solubility form, which greatly reduces its toxicity (availability).

Substrate interstitial $\mathrm{Hg}$ concentration appeared to increase slightly in all substrates with increasing salinity levels. Although the interstitial $\mathrm{Hg}$ concentration in the DC-B substrate reached $5.61 \mu \mathrm{g} / \mathrm{g}$ at the $9 \mathrm{ppt}$ salinity level, it was reduced to $0.46 \mu \mathrm{g} / \mathrm{g}$ at the end of the $36 \mathrm{ppt}$ salinity level, indicating that the substrate had become stable by the end of the study. No significant differences among substrates were detected for any other metals of concern $(\mathrm{Cd}, \mathrm{Cr}$, $\mathrm{Pb}$, and $\mathrm{Ni}$ ). Accumulation is known to vary among metals and plants tend to accumulate metals in belowground tissue at higher rates than in aboveground tissue (Fergusson 1990). However, belowground tissue can experience a high rate of leaching of metals when the soil is rinsed of sediment prior to analysis. Furthermore, accumulation of metals up the food chain often begins with consumption of plant material that is available above the sediment surface. Therefore, only 
aboveground material was analyzed in this study to maintain consistency during analysis. Acid digestions of the DC-B substrate at the end of this study did indicate that some metals had been removed from the substrate by the third year of the study. The lack of these contaminants in aboveground tissue, especially given the high levels of metals in both in the DC-B substrate and plant tissue in the first year study, suggests that uptake of certain elements by the plants and their subsequent harvest in year two of the study, were involved in these processed drill cuttings becoming more stable and usable by the third year. This is especially true of $\mathrm{Ba}$ in the DC-B substrate, which had an initial acid-digestion sediment Ba concentration of $14,500 \mu \mathrm{g} / \mathrm{g}$ that was reduced to $779.7 \mu \mathrm{g} / \mathrm{g}$ by the end of the third year. If the vegetation is indeed responsible for the reduction in soil contaminants, then phytoremediation (via plant uptake and harvest) of processed drill cuttings is an aspect of drill cuttings remediation that should be further investigated.

\section{Vegetation Performance}

The two prime indicators of plant growth used in this experiment were net $\mathrm{CO}_{2}$ assimilation rate (photosynthesis) and biomass partitioning. Net $\mathrm{CO}_{2}$ assimilation rates were measured at each salinity level and can thus be used to evaluate plant responses to substrate and hydrologic regime at different salinity levels. Biomass was harvested at the conclusion of the experimental period and therefore represents the cumulative effects of substrate and hydrology across all salinity levels through time. Plant biomass is recognized as an integrated measure of plant response to various environmental stresses through time (Larcher 1995).

Net $\mathrm{CO}_{2}$ assimilation rates under freshwater conditions indicated significantly lower plant performance when plants were grown on the DC-B substrate, corroborating the previous studies. However, a significant interactive effect of salinity and substrate was detected, in which plants grown on the DC-B substrate had rates of net $\mathrm{CO}_{2}$ assimilation comparable to other substrates once salinity levels were increased. This may be explained by the observed shift to a more 
moderate $\mathrm{pH}$ in the DC-B substrate under saline conditions. Although analysis of plant biomass would indicate that plants were performing significantly worse in the DC-B substrate than in other substrates, one must take into account that biomass values were influenced by the time spent at 0 -ppt, and therefore, may not accurately reflect salinity-substrate interactions. All net $\mathrm{CO}_{2}$ assimilation rates under saline conditions showed no significant differences among either substrate type or hydrology regime for all species. This indicates that, after two years in a simulated wetland environment, drill cuttings processed by this technique are as suitable for wetland restoration projects as topsoil, or a dredge spoil/drill cuttings mix, in terms of supporting appropriate wetland vegetation. Two of the most wide-spread brackish and salt marsh plant species of Louisiana, S. alterniflora and S. patens, exhibited excellent growth, both in terms of net $\mathrm{CO}_{2}$ assimilation and total biomass, indicating that they would be good candidates for this type of wetland restoration project. Although no differences were detected in the performance of S. cynosuroides when grown on processed drill cuttings or on topsoil or dredge spoil, this species is still not a viable candidate for creating wetlands in this fashion. Spartina cynosuroides exhibited high mortality of tissue and relatively low photosynthetic rates throughout the experiment regardless of substrate type. This can probably be attributed to a low tolerance to transplanting stress. Because the grasses utilized in this experiment are widespread throughout Atlantic and Gulf Coast marshes (S. alterniflora, S. patens, and S. cynosuroides) and Avicennia germinans is a common tropical and subtropical mangrove, the results of this project may be applied to many coastal areas (Godfrey and Wooten 1979).

No advantage was discerned by any of the genotypes tested in regard to establishing and growing in either of the processed drill cuttings, suggesting that intraspecific variation in tolerance of $S$. patens and $S$. alterniflora to substrate type is quite low. No differences were 
detected among genotypes with regard to hydrologies, again indicating that intraspecific variation in flooding tolerance may be low in the genotypes assessed. However, these statements are made cautiously because our earlier studies on more recently processed drill cuttings did reveal several differences among genotypes (Shaffer et al. 1998). Also, it is important to note that although there is a bounty of useful applications for genotype research and plant selection, the dangers of over-reliance on single genotypes (or varieties), whether in agriculture or wetland creation, can be disastrous should the environment change drastically over time, or should a disease or pest outbreak occur. Therefore, we recommend that the use of selected genotypes be limited to extremely stressful environments in need of rehabilitation.

In summary, this study has important implications for the use of processed drill cuttings in wetland rehabilitation in Louisiana and other portions of the globe. Previous studies on processed drill cuttings have indicated that the potential for their utilization in wetland rehabilitation existed, but that plant performance when grown on processed drill cuttings was often reduced from that of other substrates, or there was concern about the safety of the processed material under various environmental scenarios. This study has illustrated that processed drill cuttings have the potential to serve as suitable and nontoxic substrates capable of supporting high rates wetland plant growth under a range of environmental conditions. However, if processed drill cuttings are to become a viable option as a substrate source in wetland rehabilitation, we recommend further refinement in the formulation of environmentally safe, water-based drilling fluids. Rather than attempt to further develop encapsulation techniques that are both truly safe and conducive to plant growth in wetland environments, it may prove more expedient to formulate water-based drilling fluids with wetland rehabilitation in mind. 



\section{Literature Cited}

Barras, J.A., P.E. Bourgeosis, and L.R. Handley. 1994. Land loss in coastal Louisiana 19561990. National Biological Survey, National Wetlands Research Center Open Report 94$01,4 \mathrm{pp}$.

Bourg A.C.M. and J.P.G. Loch. 1995. Mobilization of metals as affected by $\mathrm{pH}$ and redox conditions. in Biogeodynamics of pollutants in soils and sediments: risk assessment of delayed and non-linear responses. Springer-Verlag Berlin, Germany.

Carbonell, A.A., R. Pulido, R.D. DeLaune, and W.H. Patrick Jr. 1999. Soluble barium in barite and phosphogypsum amended Mississippi River alluvial sediment. Journal of Environmental Quality. 28:316-321.

Chaineau, C.H., J.L. Morel, J. Oudot, 1996. Land treatment of oil based drill cuttings in an agricultural soil. Journal of Environmental Quality. 25: 858-867.

Chaudhry, F.M., A. Wallace, R.T. Mueller. 1977. Barium toxicity in plants. Communications in soil science and plant analysis. 8: 795-797.

Cipollini, M.L. and J.L. Pickering, 1985. Determination of the phytotoxicity of barium in leachfield disposal of oil well brines. Plant and Soil. 92: 159-169.

Coleman, J.M., H.H. Roberts, and G.W. Stone. 1998. Mississippi River Delta: an overview. Journal of Coastal Research. 14: 698-716.

Dai, T. and R.G. Wiegert, 1997. A field study of photosynthetic capacity and its response to nitrogen fertilization in Spartina alterniflora. Estuarine, Coastal, and Shelf Science. 45: 273-283. 
Day, J.W. Jr., D. Pont, P.F. Hensel, and C. Ibanez 1995. Impacts of sea-level rise on deltas in the Gulf of Mexico and the Mediterranean: The importance of pulsing events to sustainability. Estuaries. 18(4): 636-647.

Day, J.W. Jr., J. Rybczyk, F. Scarton, A. Rismundo, D. Are, and G. Cecconi. 1999. Soil accretionary dynamics, sea-level rise and the survival of wetlands in Venice Lagoon: a field and modelling approach. Estuarine, Coastal, and Shelf Science. 49: 607-628.

DeLaune, R.D., W.H. Patrick Jr., and J.M. Brannon. 1976. Nutrient transformations in Louisiana salt marsh soils. Center for Wetland Resources, Louisiana State University. Baton Rouge. Sea Grant Publication No. LSU-T-76-009.

DesRoches, D.J. 1998. Restored Drill Cuttings: A mesocosm approach to determine the suitability as a substrate for the wetlands restoration and creation. Masters thesis.

Dietrich, G., K. Kalle, W. Krauss, and G. Siedler, 1980. General Oceanography second edition. John Wiley and Sons. New York.

Dunbar, J.B., L.D. Britsch, and E.B. Kemp III. 1990. Land loss rates, Report 2: Louisiana Chenier Plain. US Army Corps of Engineers Waterways Experiment Station. Vicksburg Mississippi. Technical Report LG-90-2.

Gambrell, R.P., J.B. Wiesepape, W.H. Patrick Jr., M.C. Duff. 1991. The effects of pH, redox, and salinity on metal release from a contaminated sediment. Water, Air, and Soil Pollution 57: $359-367$.

Gray, G.R. and H.C.H. Darley, 1980. Composition and properties of oil well drilling fluids, 4th edition. Gulf Publishing Co., Houston Texas, 630pp.

Fergusson, J.E. 1990. The heavy elements chemistry, environmental impact and health effects. Pergamon Press. Elmsford, New York. 
Faulkner, S.P., W.H. Patrick Jr., R.P. Gambrell. 1989. Field techniques for measuring wetland soil parameters. Soil Sci. Soc. Am. J. 53: 883-890.

Girden, E.R 1992. ANOVA Repeated Measures. Sage Publications. Newbury Park, California. 77.

Godfrey, R.K. and J.W. Wooten. 1979. Aquatic and Wetland Plants of the Southeastern United States. The University of Georgia Press. Athens, Georgia.

Gray and Darley 1980. Composition and properties of oil well drilling fluids, fourth edition, Gulf Publishing Co., Houston, Texas 630 pp.

Hester, M.W. and I.A. Mendelssohn. 1995. Intraspecific variation in salt tolerance and morphology in the coastal grass Spartina patens (Poaceae). American Journal of Botany. 83(12): 1521-1527.

Kinraide, T.B. and D.R. Parker. 1987. Cation amelioration of aluminum toxicity in wheat. Plant Physiology. 83: 546-551.

Kelley, S. and I.A. Mendelssohn. 1995. An evaluation of stabilized, water-based drill cuttings and organic compost as potential substrate sources for marsh restoration and creation in coastal Louisiana. Ecological Engineering. 5: 497-517.

Larcher, W. 1995. Physiological Plant Ecology third edition. Springer-Verlag. Berlin, Germany. Mendelssohn, I.A., K.L. Mckee, W.H. Patrick Jr. 1981. Oxygen deficiency in spartina alterniflora roots: Metabolic adaptation to anoxia. Science. 214: 439-441.

Mendelssohn, I.A. and K.L. Mckee. 1988. Spartina alterniflora dieback in Louisiana: timecourse investigation of soil waterlogging effects. Journal of Ecology. 76: 509-521.

Mitsch, W.J. and J.G. Gosselink. 1993. Wetlands second edition. Van Nostard Reinhold. New York, NewYork. 
Neter, J., Wasserman, W., and Kutner, M.H. 1990. Applied Linear Statistical Models third edition. Irwin. Boston, Massachusetts.

Penland, S. and K.E. Ramsey. 1990. Relative sea-level rise in Louisiana and the Gulf of Mexico. Journal of Coastal Research. 6: 323-342.

Ponnamperuma, F. N. 1972. The chemistry of submerged soils. Advan, Agron. 24:29-88. Academic Press, New York.

Shaffer, G.P., M.W. Hester, Miller S., DesRoches, D.J., Souther, R.F. Childers G.W. Campo F..M., 1996. Restored drill cuttings for wetlands: Year one results of a mesocosm approach to emulate field conditions under varying hydrologic regimes. National Petroleum Technology Program, U.S. Department of Energy, Technical Report.

Shaffer, G.P., M.W. Hester, Miller S., DesRoches, D.J., Souther, R.F. Childers G.W. Campo F..M., 1998. Restored drill cuttings for wetlands: Results of a two year mesocosm approach to emulate field conditions under varying hydrologic regimes. National Petroleum Technology Program, U.S. Department of Energy, Technical Report.

Smith, K.A. 1971. The comparative uptake and translocation by plants of calcium, strontium, barium, and radium II Triticum vulgare (wheat). Plants and Soil. 34, 643-651.

SPSS 1998 SYSTAT for Windows.

Turner, R.E. 1997. Wetland loss in the northern Gulf of Mexico: multiple working hypotheses. Estuaries. 20(1): 1-13.

USEPA 1985. Draft health effects criteria document for Barium. USEPA Criteria and Standards Division, Office of Drinking Water, Washington, DC. 
Appendix 

Table. A-1 Factor Analysis of the 0-ppt salinity level substrate interstitial water elemental concentrations

Principal

Component:

$\underline{\mathrm{PC}} 1 \quad \mathrm{PC} 2 \quad \mathrm{PC} 3 \quad \mathrm{PC} 4$

Eigenvalue:

$\begin{array}{llll}6.555 & 2.526 & 1.870 \quad 2.203\end{array}$

Percent explained variation:

$\begin{array}{llll}32.77 & 12.63 \quad 9.352 \quad 11.02\end{array}$

Rotated Loading Matrix (VARIMAX)

\begin{tabular}{lrrrr} 
Variable & $P C_{1}$ & $P C_{2}$ & $P C_{3}$ & $P C_{4}$ \\
\hline & & & & \\
$\mathrm{Mg}$ & 0.978 & 0.026 & 0.032 & -0.009 \\
$\mathrm{Cr}$ & 0.949 & -0.031 & 0.000 & 0.940 \\
$\mathrm{Ni}$ & 0.939 & 0.005 & 0.010 & -0.008 \\
$\mathrm{Ca}$ & 0.906 & 0.023 & -0.003 & -0.035 \\
$\mathrm{Cd}$ & 0.840 & -0.104 & 0.106 & -0.106 \\
$\mathrm{As}$ & 0.773 & 0.124 & -0.094 & -0.320 \\
$\mathrm{Na}$ & 0.759 & -0.303 & -0.003 & -0.200 \\
$\mathrm{~Pb}$ & 0.698 & 0.113 & 0.137 & 0.358 \\
$\mathrm{pH}$ & -0.133 & -0.810 & -0.059 & -0.264 \\
$\mathrm{Al}$ & -0.144 & -0.734 & 0.009 & 0.018 \\
$\mathrm{P}$ & -0.082 & 0.576 & 0.059 & 0.071 \\
$\mathrm{Redox} 1 \mathrm{~cm}$ & 0.059 & 0.152 & 0.918 & 0.047 \\
Redox $15 \mathrm{~cm}$ & -0.107 & -0.030 & 0.910 & 0.036 \\
Fe & 0.006 & 0.065 & -0.062 & 0.922
\end{tabular}


Table. A-2 Factor Analysis of the 36-ppt salinity level substrate interstitial water elemental concentrations.

Principal

Component:

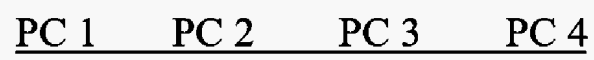

Eigenvalue:

$\begin{array}{llll}4.818 & 2.213 & 2.153 & 2.147\end{array}$

Percent explained variation:

$25.36 \quad 11.65 \quad 11.33 \quad 11.30$

Rotated Loading Matrix (VARIMAX)

$\begin{array}{lrrrr}\mathrm{Mg} & 0.151 & 0.008 & 0.116 & 0.794 \\ \mathrm{Cr} & 0.952 & 0.077 & -0.097 & 0.009 \\ \mathrm{Ni} & 0.975 & 0.045 & 0.033 & 0.116 \\ \mathrm{Ca} & -0.041 & -0.147 & -0.331 & 0.665 \\ \mathrm{As} & 0.925 & 0.087 & 0.001 & -0.001 \\ \mathrm{Na} & 0.549 & -0.376 & 0.060 & 0.338 \\ \mathrm{~Pb} & 0.961 & 0.078 & -0.079 & -0.125 \\ \mathrm{pH} & -0.009 & -0.099 & -0.651 & -0.369 \\ \mathrm{Al} & 0.713 & -0.009 & 0.129 & 0.481 \\ \mathrm{Fe} & 0.111 & -0.016 & 0.807 & -0.014 \\ \mathrm{Cu} & 0.098 & 0.945 & 0.005 & -0.120 \\ \mathrm{Mn} & -0.114 & 0.035 & 0.780 & -0.201 \\ \mathrm{Zn} & -0.024 & 0.948 & 0.050 & -0.088\end{array}$


Table. A-3 Factor Analysis of totally potentially extractable DC-B sediment elemental concentrations (resulting from acid digestion).

Principal

Component:

Eigenvalue:

Percent explained variation:

$\underline{\mathrm{PC}} 1 \quad \mathrm{PC} 2 \quad \mathrm{PC} 3 \quad \mathrm{PC} 4$

$\begin{array}{llll}5.665 & 4.947 & 2.099 & 1.836\end{array}$

$\begin{array}{llll}35.41 & 31.92 & 13.12 & 11.47\end{array}$

Rotated Loading Matrix (VARIMAX)

$\begin{array}{lrrrr}\text { Variable } & \mathrm{PC} 1 & \mathrm{PC} 2 & \mathrm{PC} 3 & \mathrm{PC} 4 \\ \mathrm{Fe} & 0.974 & -0.088 & 0.188 & 0.010 \\ \mathrm{Mg} & 0.959 & -0.210 & 0.067 & 0.127 \\ \mathrm{Al} & 0.943 & -0.226 & 0.077 & 0.049 \\ \mathrm{Ca} & 0.924 & 0.118 & 0.110 & -0.031 \\ \mathrm{P} & 0.817 & 0.464 & -0.085 & 0.060 \\ \mathrm{Ni} & 0.789 & 0.534 & 0.117 & -0.172 \\ \mathrm{~Pb} & -0.090 & 0.970 & -0.037 & 0.145 \\ \mathrm{As} & -0.039 & 0.924 & -0.092 & -0.340 \\ \mathrm{Cd} & 0.225 & -0.848 & 0.469 & 0.027 \\ \mathrm{Cr} & 0.089 & 0.833 & 0.110 & -0.379 \\ \mathrm{Na} & -0.024 & -0.167 & 0.911 & 0.209 \\ \mathrm{Ba} & 0.008 & -0.158 & 0.087 & 0.921 \\ \mathrm{~K} & 0.272 & -0.053 & 0.445 & 0.583\end{array}$


Table. A-4 Factor Analysis of acid digested plant tissue elemental concentrations.

Principal

Component:

$\underline{\mathrm{PC} 1}$ PC $2 \quad$ PC $3 \quad$ PC 4

Eigenvalue:

$\begin{array}{llll}5.189 & 2.688 \quad 2.374 \quad 1.885\end{array}$

Percent explained variation:

$32.43 \quad 16.80 \quad 14.84 \quad 11.78$

Rotated Loading Matrix (VARIMAX)

\begin{tabular}{lrrrr} 
Variable & $P C 1$ & $P C 2$ & $P C 3$ & $P C 4$ \\
\hline $\mathrm{Cu}$ & & & & \\
$\mathrm{Zn}$ & 0.884 & 0.017 & -0.058 & -0.322 \\
$\mathrm{Cd}$ & 0.316 & 0.658 & 0.383 & -0.224 \\
$\mathrm{~Pb}$ & 0.871 & 0.097 & 0.169 & -0.121 \\
$\mathrm{Cr}$ & 0.878 & -0.007 & 0.180 & 0.129 \\
$\mathrm{Ni}$ & 0.850 & 0.347 & 0.014 & 0.008 \\
$\mathrm{As}$ & 0.714 & 0.101 & 0.563 & -0.098 \\
$\mathrm{Fe}$ & 0.849 & -0.014 & 0.060 & 0.217 \\
$\mathrm{Mn}$ & 0.286 & 0.297 & 0.664 & 0.033 \\
$\mathrm{Ca}$ & -0.078 & -0.013 & 0.941 & 0.030 \\
$\mathrm{Mg}$ & 0.184 & 0.646 & 0.410 & -0.119 \\
$\mathrm{P}$ & 0.122 & 0.815 & 0.053 & 0.197 \\
$\mathrm{~K}$ & 0.158 & 0.264 & 0.417 & 0.637 \\
$\mathrm{Na}$ & 0.081 & 0.078 & -0.277 & 0.745 \\
& -0.397 & 0.783 & -0.169 & 0.243
\end{tabular}


A-5 Schematic of Mesocosm Facility

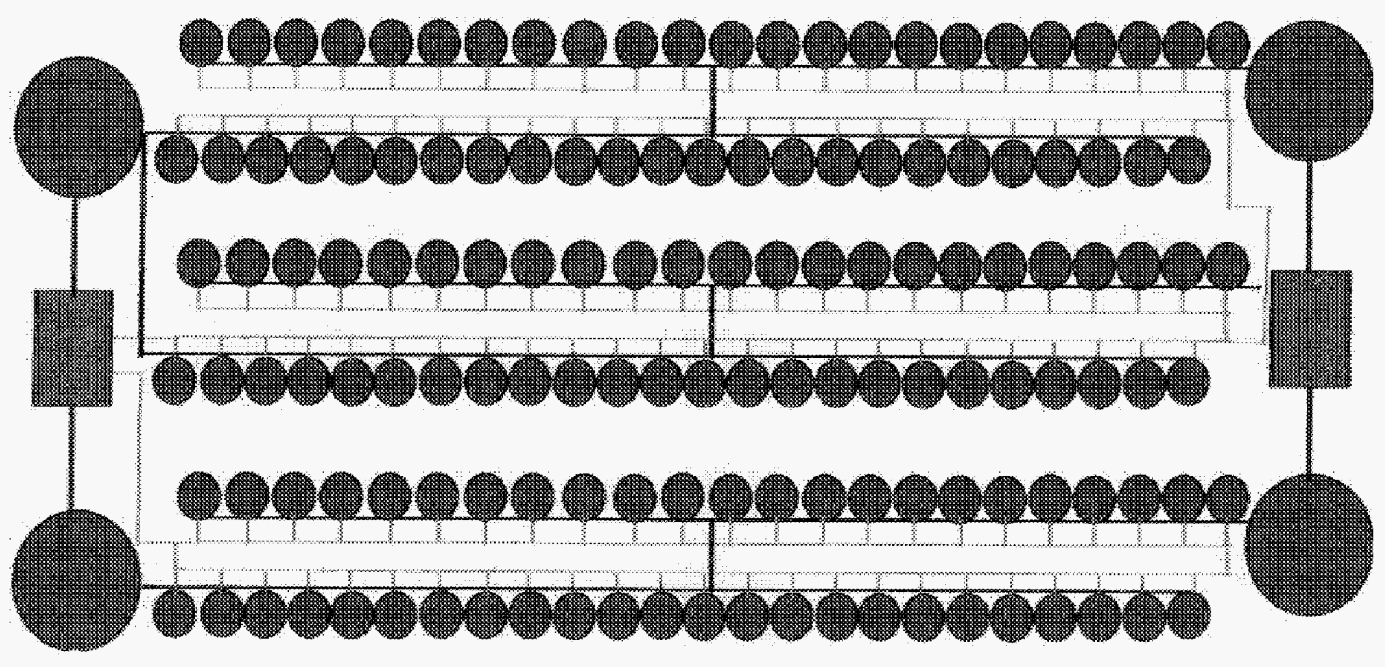



